

$$
\begin{aligned}
& \text { MK } \\
& 3780 \\
& J 6 x \\
& \text { CHM }
\end{aligned}
$$



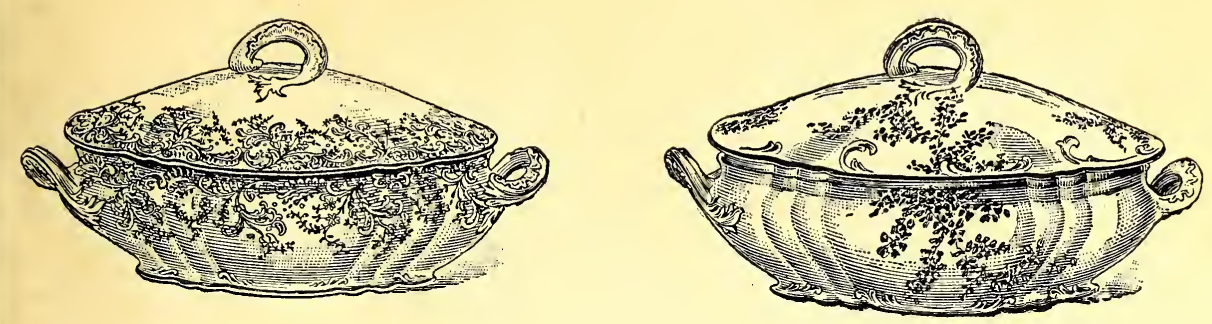

\section{A Lasting Pleasure *}

one of

\section{J0HN MADDOCK \& SONS, Ltd.}

\section{* Royal Vitreous *}

Dinner, Tea or Toilet Sets

They cost just a little more than the ordinary kinds, but all better things do

\section{Beautiful Shapes \& क}

Tasty, Modern, Up-to-date Decorations Novel, Attractive Colors

For sale by all First-Class Dealers in Pottery who will substantiate every claim we have advanced $* * * *$
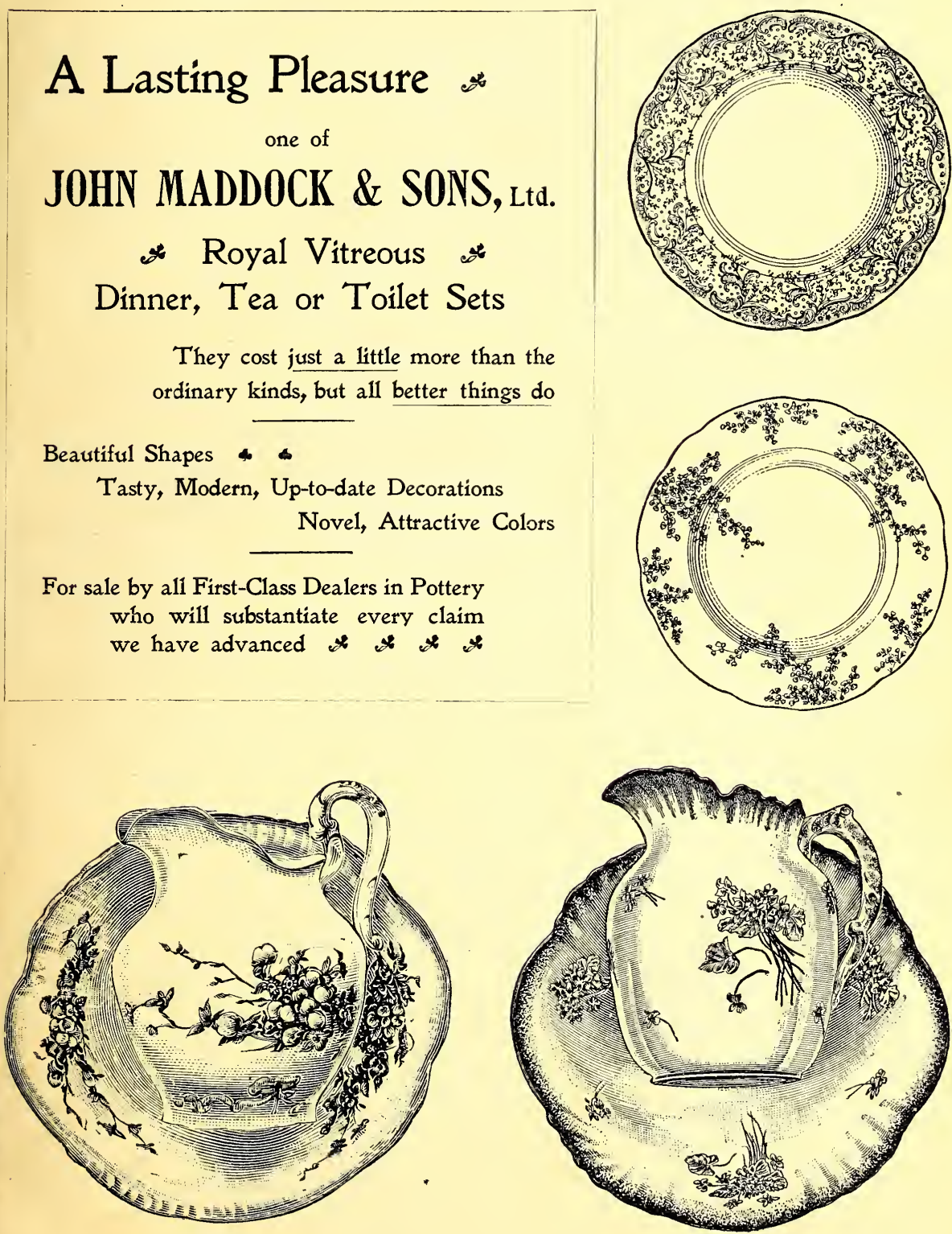

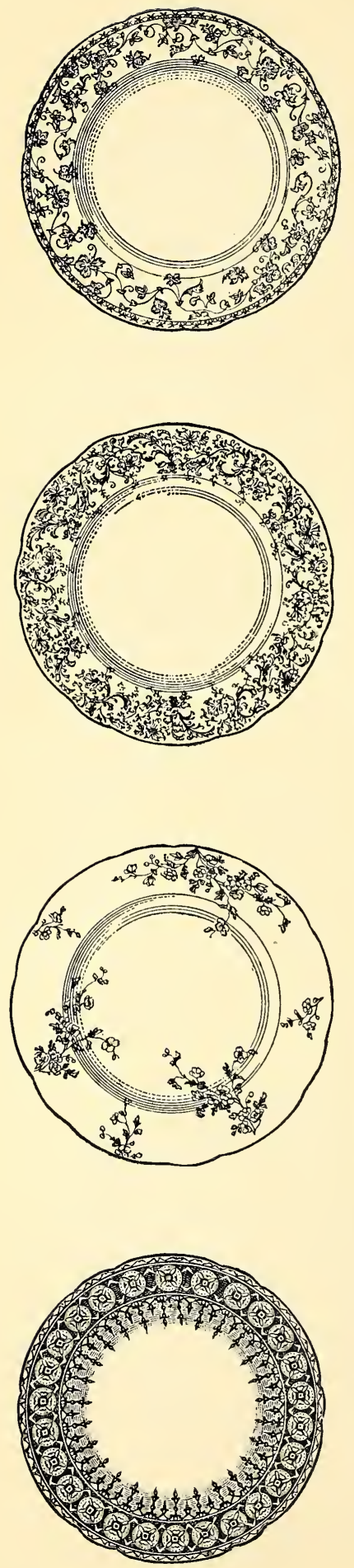

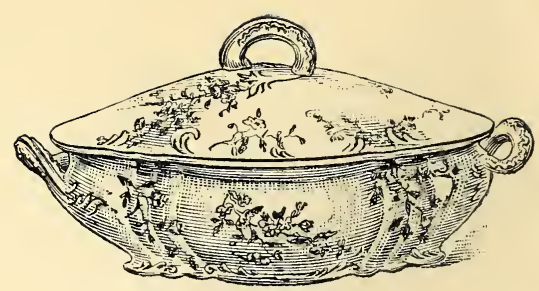

\section{Look at this Stamp}

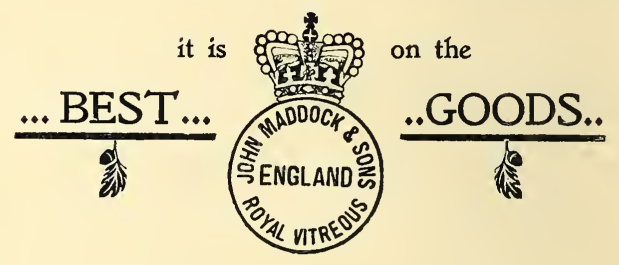

The Potters' Art can produce

They are made by

JOHN MADDOCK \& SONS, Ltd., BURSLEM, ENGLAND.

\section{CAUTION.}

Be sure in buying that the name MADDOCK and ENGLAND are BOTH on the stamp as our mark has been extensively copied.

For Hotels, Boarding-houses, etc., we make goods of special strength for their requirements.

Inquire about Maddock's goods at your nearest China Store. 


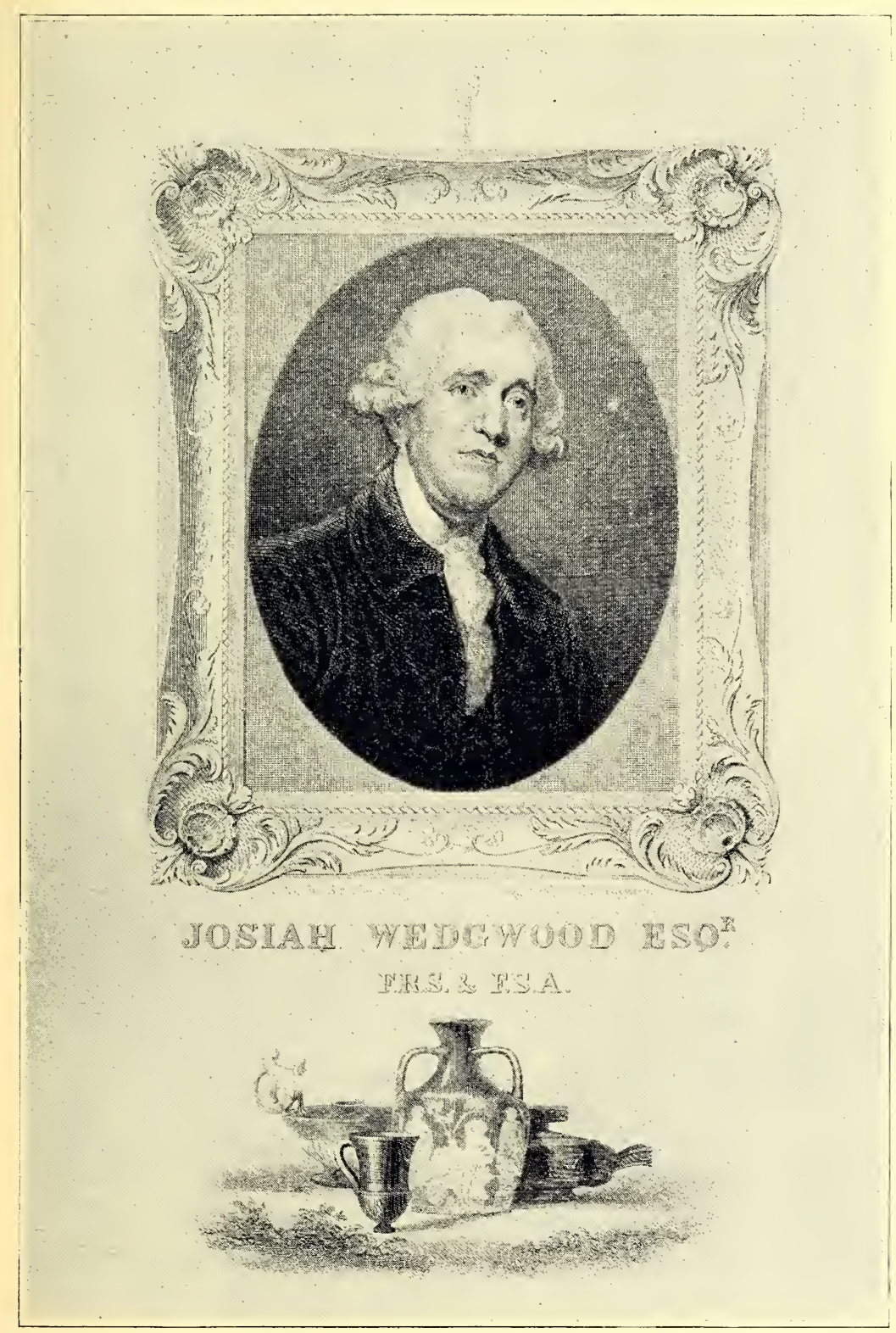




\section{CONTENTS.}

BY WAY OF PREFACE.

Page.

THE ANTIQUITY OF POTTERY

AN ICONOCLAST

EARLY ENGLISH POTTERY

Dwight Stoneware-The Elers-Salt Glaze John Astbury's Discovery of Flint-

Ralph Shaw-Whieldon-Cookworthy-The New Hall China-Liverpool-LeedsRockingham Ware.

JOSIAH WEDGWOOD AND HIS SUCCESSORS

MINTONS

SPODE-COPELAND-PARIAN

DAVENPORTS

CAULDON (BROWN-WESTHEAD MOORE \& CO.)

AMERICAN HISTORICAL EARTHENWARE

FOR THE AMERICAN MARKET.

T. \& R. Boote-The Old Hall Earthenware Co.-Geo. Jones \& Sons-Johnson

Bros.-J. \& G. Meakin-Furnivals-Burton Factories-Burmantofts Luca della Robbia Pottery.

JOHN MADDOCK \& SONS

CHELSEA.

BOW..

DERBY

CAUGHLEY-COALPORT

WORCESTER

G. GRAINGER \& CO

LOWESTOFT

DOULTON

BELLEEK-W. H. GOSS.

PÂTE.SUR-PÂTE, BY L. SOLON.

THE STAFFORDSHIRE POTTERIES

FRANCE. BERNARD PALISSY

FAÏENCE D'OIRON

FRENCH FAÏENCE AND EARTHENWARE

Nevers-Custode Ware-Rouen-Moustiers-Strasburg-The Hannongs SincennyQuimper-Lille-Niederviller-Count Custine-Nancy-Islettes-Aprey-MarseillesSceaux-Other Faience Factories-English Potters in France-Longwy-Montereau -Creil-Gien-Sarreguemines-Choisy le Roi-Bordeaux - Luneville-Montagnon of Nevers-Clement Massier-Deck of Paris

FRANCE. PORCELAIN

Poterat-St. Cloud-Chantilly-Vincennes-Sevres-Mennecy-Orleans-La Courtille - Clignancourt-Rue de Bondy-Pont aux Choux.

LIMOGES

Early Faience-Alluaud-Baignol-Pouyat-Haviland \& Co.-E. Gerard, Dufraisseix

$\&$ Co. (Chas. Field Haviland)-Theo. Haviland-Delinieres-Tressemanes \& VogtLanternier-Sazarat.

ITALIAN MAJOLICA.

Hispano-Moresque - Origin of Majolica-Luca della Robbia-Gubbia lustres-

Maestro Giorgio-Castel Durante-Urbino-The Fontano's - Francesco Xanto-

Faenza-Caffaggiola - Composition of Body-Passarin-Modern reproductions-

Ginori.

CAPO DI MONTE and BUEN RETIRO

MEDICI

RHODIAN

GERMANY AND AUSTRIA

Bottger and Meissen-Hochst-Fürstenburg-Frankenthal-Ludwigsburg (Kronenburg)-Baden-Berlin.

GERMANY AND AUSTRIA, MODERN

Gres des Flandres-Jacquelaine of Bavaria-Villeroy \& Boch-Hulschenreuther-

Gerbinge-Rudolstadt-Fischer \& Meig-Zsolnay - Mehlen-Meissen - Wessel-

Schwarz-Dernheim, Koch \& Fischer-Vienna.

ROYAL DANISH.

DELFT AND TOURNÄY

SWEDEN

CHINA AND JAPAN

Rörstrand-Stralsund-Marieburg-Gustafsburg.

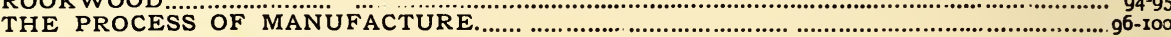

BEST, SECONDS, and THIRDS.

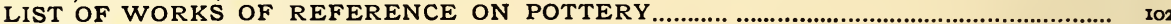

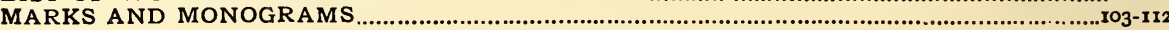

The frontispiece is from an original engraving after Sir Joshua Reynolds, kindly loaned for reproduction, by E. Boote, Esq., New York. 
COPIOUSLY ILLUSTRATED FROM RARE EXAMPLES, AND WITH MANY MARKS AND MONOGRAMS NOW FIRST PUBLISHED.

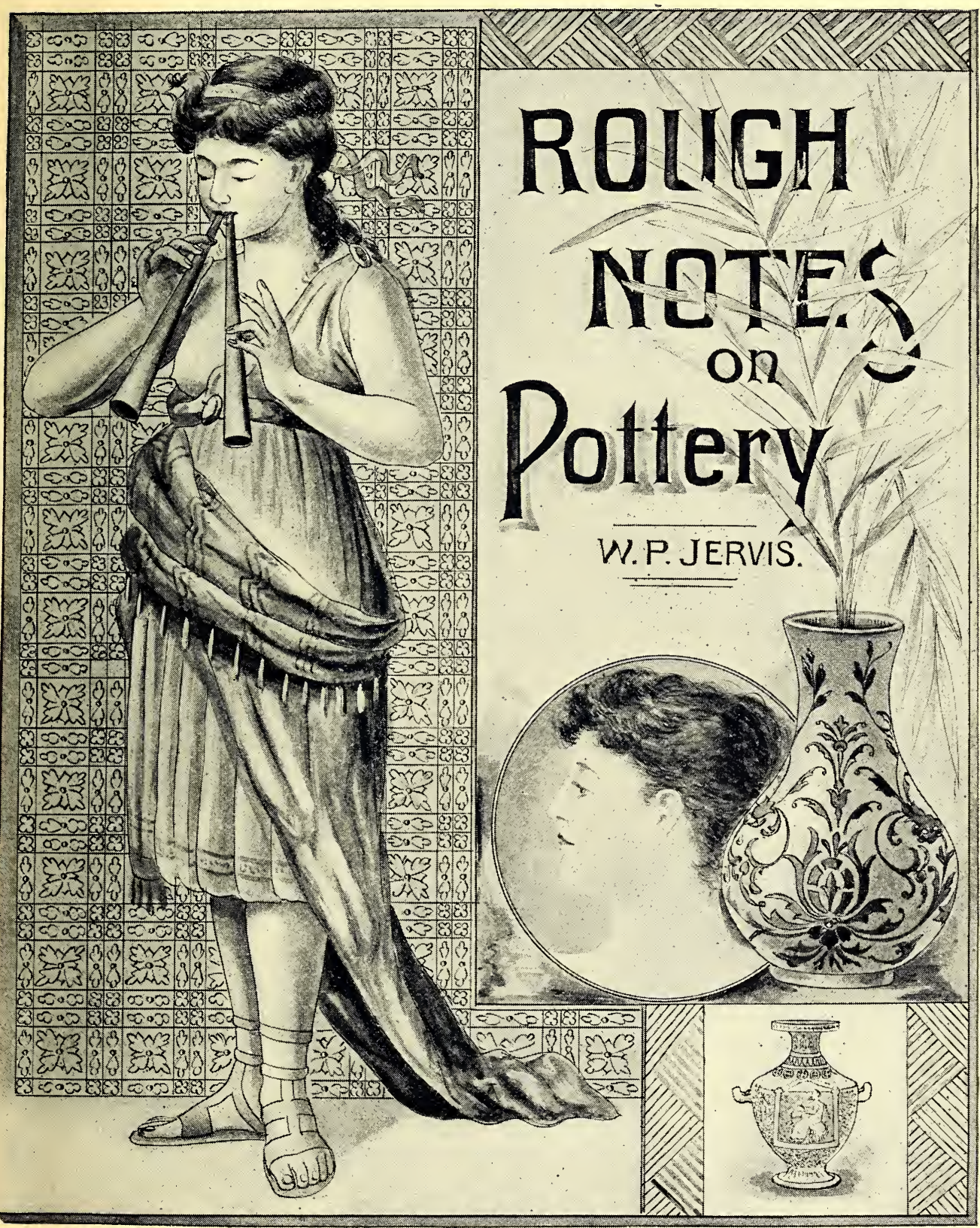

NEWARK, N. J.

W. P. JERVIS,

62 JAMES STREET 


\section{By Way of Preface.}

W

HO has not lingered with a feeling of enjoyment in some great museum or exhibit, over a collection of ancient and modern pottery, in doubt whether to admire most some quaint piece with its lizards and newts, direct from the hand of the great Palissy, or a specimen of modern china from one of the great European hives of industrial art; so delicate that it seems as if the lightest zephyr might waft it away? Who but has read of the struggles of Palissy, with a faith so sublime that the doors, the very furniture of the house, go to feed the kiln? Of Frederic Böttger, confined by a royal despot who sought to wring from him the secret he was supposed to possess of transmitting baser metals into gold? Or later, the struggles of Astbury and Wedgwood, the pioneers of English Ceramic art? You have seen vases and platters from Rhodes, centuries old, made by Persians driven into exile there, side by side with pieces varying but little in feeling and design, fresh from the kiln, by the same wanderers, from the factory at Jeypore. Delicate little bisque statuettes by Cyfflé, beside a priceless piece of Faïence d'Oiron, each specimen of which is so carefully located that it can be traced from hand to hand with as much certainty as the genealogy of some illustrious princess.

What thought and brain power, what an expenditure of wealth and muscle has it taken to produce this little cup, worth no more than a few cents; what a number of hands it has passed through since it lay in embryo in the mountain of King-tehChin, or in the heart of the mine amid the rugged Cornish hills?

And with some such thought has come the desire for knowledge; but the textbooks have been too technical, have been written from a standpoint too high for any but the pronounced enthusiast, and the desire has gradually faded-disappeared.

In the following pages I have not attempted any exhaustive account of the history of Ceramics, but have endeavored to give some interesting facts regarding the best known varieties ; to avoid the inaccuracies of fugitive newspaper contributions, and in a discursive, but I trust, an acceptable manner to awaken or reawaken an interest in this most fascinating art. Some features have been intro. duced that so far as I am aware, have not been attempted before, though this does not make me any the less diffident in submitting it to your kindly consideration. This little work is only intended as a primer. Technical terms have been avoided so far as possible, and when used are fully explained. I have not burdened the text with ponderous reflections or criticisms, but I hope it will possess one quality at least, that of accuracy. I am indebted for the historical facts given here to the works on Pottery, of which I have given a list in another place, together with voluminous notes on Staffordshire pottery, made when a resident there; and to the courtesy of manufacturers or their agents where personal intercourse has been practicable.

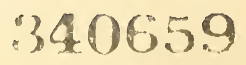




\section{The Antiquity of Pottery.}

$\mathrm{T}$

HE history of Pottery is the history of the world. The art of making it was practiced by all prehistoric races, from the Neolithic age downwards. Egyptian slabs, moulded in slight relief or painted in various colors, were used to decorate the palace of Rameses II., in the 14th Century, B. C. Fully ten centuries before this time the Chinese, with their earlier civilization and culture, manufactured pottery. The Egyptians were acquainted with the use of tin to make an opaque enamel, but do not appear to have used lead, which the Assyrians two centuries later employed. In Babylon, tablets and cylinders were impressed with cuniform characters and were converted by firing into imperishable MSS. These cylinders show the marks of having been thrown on a wheel. The British Museum has a fine collection of these tablets, upwards of twentyfive thousand which Dr. Carl Bezold is now cataloging, the second volume having been recently issued.

Greek art succeeded Assyrian and flourished from the eighth to the second Century, B. C. Black figures on red body are generally ascribed to the earliest period; the red on black to about the fourth Century, B. C., when their best work was produced, and following it a period of decadence down to the second Century, B. C. The Etruscans produced black moulded ware, often with stamped bands, during the eighth Century, B. C., and from the sixth down to the second, imitations of Greek vases. From the first Century, B. C. to 500 A. D., the art found its noblest exponents in the Romans, who gave us the fine Simian ware, of a fine red sealingwax color, decorated in reliefs of really masterly modeling and often impressed with the maker's name. They also largely used the slip process of decoration, the rude prototype of the pâte-sur-pâte of the present century.

Anything like chronological order in the history of Pottery is almost impossible, but the Persians and Arabs, having learned of the potters of Greece and Rome practiced the art from the tenth to the seventeenth Centuries, when Chinese influence began to be felt. The Moslem carried it along the northern coast of Africa, and after the Moorish occupation of Southwest Europe it took root in Spain and from there spready to Italy, France and England.

Not the least curious fact is the varying fortunes it underwent; its processes lost for centuries only to be eventually re-discovered: its frequent decline in one country only to again emerge triumphant in another. The use of tin to give opaqueness to a glaze is a case in point. It was known to the Egyptians and from them passed to the Assyrians. The Persians employed it as did also the Arabs and Saracens, and by them it passed into Europe, was lost and finally perfected by Luca della Robbia in the 15th Century.

Again: Pre historic pottery had frequently incised lines or small dots made with a piece of wood and bands of ornaments made with stamps such as a hollow stick or reed. These indentations were sometimes filled with white pipe clay, forming the prototype of the Encaustic Tile of to-day. The Egyptians of the 18th and 19th Dynasties, with improved facilities and greater elaboration, produced the same result. In England it re-appeared in the form of tiles made by Monastic orders for religious purposes in the twelfth Century. It reached its zenith in the Failence d'Oiron of the sixteenth Century, and was then apparently lost until Wright re-discovered and Minton perfected it sixty-five years ago.

A striking example of the antiquity of Pottery has recently come to light in the shape of some pieces found at a depth of over thirty-nine feet in the alluvial deposits of the Nile. They have been presented to the Bristol Museum by Mr. L. Horner, an English engineer. 


\title{
An Iconoclast.
}

\begin{abstract}
THE writer of the article on Pottery in the Encyclopædia Brittanica has very pronounced views as to what constitutes Art in connection with Pottery. Here are a few of them:
\end{abstract}

Dresden Statuettes: "Some of these, especially the Watteau-like Shepherds, have a sort of feeble prettiness, but most have only little merit."

Dresden Mayflower: "Laborious to execute and extremely disagreeable to the eye."

Sèvres: "The value of Sèvres porcelain is a highly artificial and conventional one, which can hardly be considered in accordance with the ordinary rules or canons of art."

"The colors of Sèvres porcelain are generally harsh and out of harmony with the pictures they surround; the forms of the various vessels, too, are frequently very ungraceful and utterly unsuited to any plastic substance."

"Perhaps the worst taste of all is shown in some of the vases which have scrolls and sham metal work moulded and gilded to produce the effect of a porcelain vase set in ormolu mounts."

Chelsea : "The writhing masses of gold on Chelsea ware are probably the most meaningless and stupid attempts at decoration that have ever been produced."

Derby: "Unfortunately the practice of printing the underglaze patterns, instead of painting them by hand, was introduced."

Worcester: "Unfortunately the old fault of a too realistically pictorial style of painted decoration still prevails, and an immense amount of artistic skill and patient labor is practically wasted in producing minute, but not truly, decorative work."

Wedgwood: "He neglected the special requirements of fictile work. His productions, delicate and beautiful as they often are, have the characteristics of anything rather than Pottery. With great labor and expense he turned out from his workshops imitations, necessarily unsuccessful, of ancient engraved gems and cameos, of jasper, basalt or mottled marbles, of gem-like cut-glass, such as the Portland vase, and dull copies, feeble in drawing and hard in texture, of beautiful painted Greek vases. Of natural methods of decoration, suitable to pottery, or of the life and freedom of the plastic clay rising into graceful forms under the touch of the thrower's hand, aided by the rhythmical moventent of the wheel, he knew nothing. Nearly all his pottery is dully scholastic and archæological in style, and therefore must, on the whole, be regarded as a failure, though often a very clever and even beautiful failure."

Japanese Cloissonne: "A marvel of technical skill and wasted ingenuity." 


\section{Early English Pottery.}

$\mathrm{T}$

HE credit of having made the first china in England is generally credited to John Dwight, who established a manufactory at Fulham in 1671; but Mr. Solon, in his "Old English Potter," proves conclusively from examination of the recipes left by Dwight, that the distinction has been erroneously attributed to him. His stoneware was, however, of remarkable excellence, and of his figure of Meleager in the British Museum, Mr. Solon says it is worthy of an Italian Artist of the Renaissance. No light praise from such an authority. Dwight unfortunately was a man of very secretive habits and much that is valuable was lost through his having buried most of his models, \&c., just before his death.

In Staffordshire, at this period, common ware only was produced, the most notable being the slip decorated ware; when the advent of the Elers Brothers, who came over with the Prince of Orange, in 1688, and a few years afterwards commenced manufacturing at Bradwell, near Burslem, caused a great change. From the clay found at Bradwell they made an admirable red body, very dense and semi-vitrified, and decorated with raised designs made from a metal die. These designs were impressed by means of dies upon raised clay on the body of the ware and were not first made from a mould and fixed on with a slip. The glazing was effected by throwing a quantity of common sea salt into the oven when the heat was at its greatest, the fumes fixing on the surface of the ware, the soda being decomposed by the action of the silica in the body, giving a granulated appearance similar in effect to the peel of an orange.

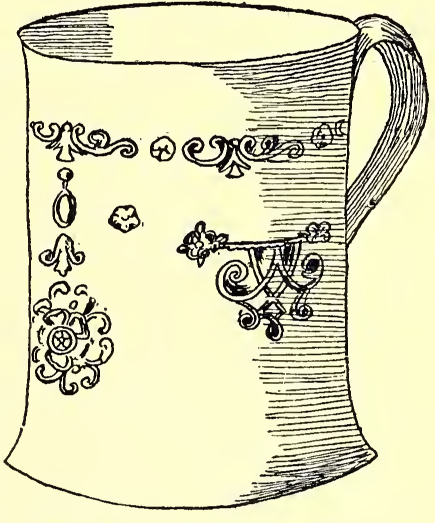
This was the first time salt glazing was practiced in Staffordshire, the old myth about its discovery by a servant of Yates having been exploded. Every possible precaution seems to have been taken by the Elers to prevent their secrets becoming known to the Burslem potters. Their store and salesroom at Dimsdale was a mile away from the works and communication was established by means of aspeaking tube composed of clay pipes. The goods were transferred at night from the works to the storeroom and only to the latter were strangers admitted. In a diary describing events between 1697 and 1703 Celia Fiennes writes: "I went to this Newcastle in Staffordshire to see the making of ye fine tea potts, Cups and Saucers of ye fine red Earth in imitation and as Curios as $\mathrm{yt}^{\mathrm{t}} \mathrm{wch}$ comes from China, but was defeated in my design, they coming to an End of their Clay they made use of for $\mathrm{y}^{\mathrm{t}}$ sort of ware, and therefore was removed to some other place where they were not settled at their work so Could not see it." The gentle Celia was evidently purposely misled, for long after the Elers left (in 1710) Astbury and others continued to use the clay, and even at the present day there are as many teapots there as were ever taken out of it. Only the least intelligent workmen were employed by the Elers as helpers, but in spite of every precaution two potters 
named Astbury and Twyford, simulating idiocy, obtained employment and managed to learn the secrets of the foreigners. In 1710 the Elers left Burslem, John Philip eventually starting and prospering as a glass and china dealer in Dublin. The ware produced by the Elers was light and delicate, chiefly small pieces such as teapots, \&c., simple and unpretentious, but on account of the peculiar decoration it had a certain character of its own and found sale at remunerative prices, teapots selling in London for 21/s. Every piece was thrown and turned, no moulds were used, even the handles being made by hand. (See illustration p. 9.) They also produced a very good black ware.

The manufacture of salt glazed ware now became general, and much ingenuity and skill was displayed in the production of models worthy of the new glaze. The Elers had numerous imitators and the trade which had been exclusively local now took a wider range. It also stimulated the potters to a desire to improve their productions, and many processes were considerably improved. Local clays had been exclusively used, but to procure greater whiteness clays were obtained from Devon and then came in 1720 John Astbury's important discovery of the use of flint. Whilst traveling to London on horseback-and he was probably the first pottery drummer who ever started out from Staffordshire-he had occasion to seek the assistance of a hostler, in consequence of some disease in his horse's eyes. He noticed that the man took a piece of flint, and burned it to a fine powder and blew it into the horse's eyes. Astbury noticing the beautiful

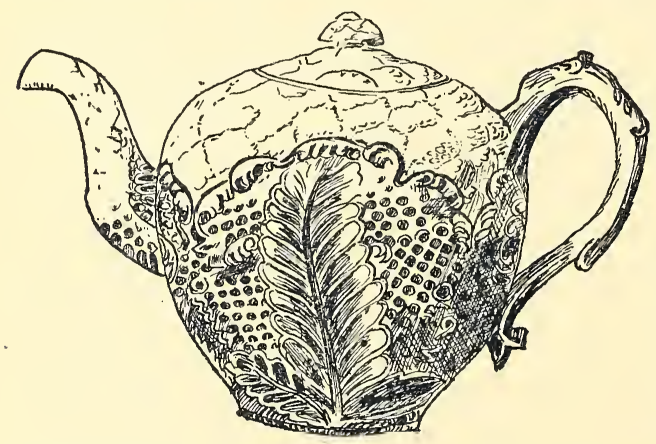
whiteness of the powder conceived the idea of using it in his pottery. The experiments he subsequently made were eminently successful. Wedgwood's improvement of cream color pales into insignificance beside a discovery such as Astbury's, and though the manner in which he obtained his information from the Elers is open to criticism, his subsequent discoveries and improvements, in which the whole district shared, should give him a prominent position amongst the old Staffordshire potters. Many writers credit this discovery to his son, but this is plainly an error. Astbury's son 'Thomas, the only one of whom we have any information, had a busi. ness at Lane Delph in 1725, improved on his father's ware and gave it the name of "Cream color." He made a great variety of goods, red and black bodies, white stone ware with salt glaze and cream color, decorated with tortoiseshell enamel. Amongst his contemporaries were Ralph Shaw, who invented the slip kiln and in a primitive form the use of stilts, \&c., in firing; John and Thomas Wedgwood, who by their experiments, particularly with clays, advanced considerably the quality of the body, and Whieldon, whose name more than any other is associated with early Staffordshire history. He was a manufacturer at Little Fenton, and Astbury, Spode and many other well known potters served their apprenticeship to him. Josiah Wedgwood when quite a young man was his partner, and during this time his mottled and other wares were of high character. His early productions consisted of knife 
handles, snuff boxes, \&c., in a beautiful tortoiseshell enamel, and these he usually carried around himself in a basket and being much like agate they found a ready sale.

"Rough potters seemed they, trading soberly,

With panniered asses driven from door to door."-Wordsworth.

He successfully imitated the Chinese double shell teapots the outer one pierced with a design of leaves, \&c., covering the shape with a sort of lace work, very effective in appearance and really admirable specimens of the potter's art.

Turning from the Earthenware to China, about the middle of the century the Chelsea, Worcester and Derby works were started, and these are all treated under their respective headings. From 1760 to 1772, William Cookworthy manufactured at Plymouth and Bristol (plate 1, figures 6 and 7) the first hard porcelain ever made in England, having discovered the half decomposed Kalonic clay in Cornwall. He disposed of his patent to Richard Champion, who in turn sold it to a company of Staffordshire potters-Enoch Wood amongst the number-who commenced its manufacture at Keeling's pottery at Tunsiall ; but in consequence of a disagreement between the partners it was transferred to the New Hall Works, Hanley. Here china, precisely similar in body and glaze to that made at Bristol, was produced under the direction of Champion from 1778 to 1810 , when bone china superseded it. The manufacture ceased altogether in 1825, and a part of the premises are now occupied by Thomas Booth \& Son.

Early in 1700 Liverpool had extensive manufactories of Delft ware, though even in the previous century some pieces were made there, a Delft mug in the Liverpool Museum, marked "John Williamson 1645," being generally considered as of local make. But it was not until Sadler's invention of printing from copper plates that the art assumed importance. Wedgwood, amongst many others, sent his ware to be printed at Liverpool. Richard Chaffers was then established as a manufacturer and in the matter of colors Wedgwood regarded him as no mean rival. About 1760, Pennington (plate 4, figure 12) was making Delft, and appears to have divided the honors, especially in punch bowls, with his rival, Shaw. He eventually returned to Worcester. In 1790, Richard Abbey established a pottery, which in 1797 passed into the hands of Messrs. Worthington, who called it the Herculaneum Pottery (plate 4, page 14) making a good quality of printed and painted earthenware, jugs with base relief figures and terra cotta. The workmen were brought from Staffordshire, performing the journey in canal boats. In 1833 the works passed into the hands of Case, Mort \& Co., who used the liver as a trademark, (plate 4, figure 13). In 1836, another change in the proprietary took place and the works were finally closed in 1841.

At Leeds, as early as 1770 , considerable progress had been made especially in that pure cream color ware with either embossed ${ }^{\circ}$ or pierced edges, for which it attained so considerable a celebrity. 
At Swinton, near Rotherham, late in the last century, was produced that beautiful brown glaze, afterwards designated as Rockingham, and which has since been imitated by nearly every pottery, but the care taken in its original production is lacking, and the Rockingham of to-day no more resembles the original than "C. C." does the finest china. They also produced at Swinton some very finely decorated earthenware vases, and in $\mathbf{1 8 2 5}$ added the manufacture of china. The artistic element prevailed to such an extent, that quite as important a part, that of commercialism, was overlooked, with the inevitable results. (Plate 4, figure 39).

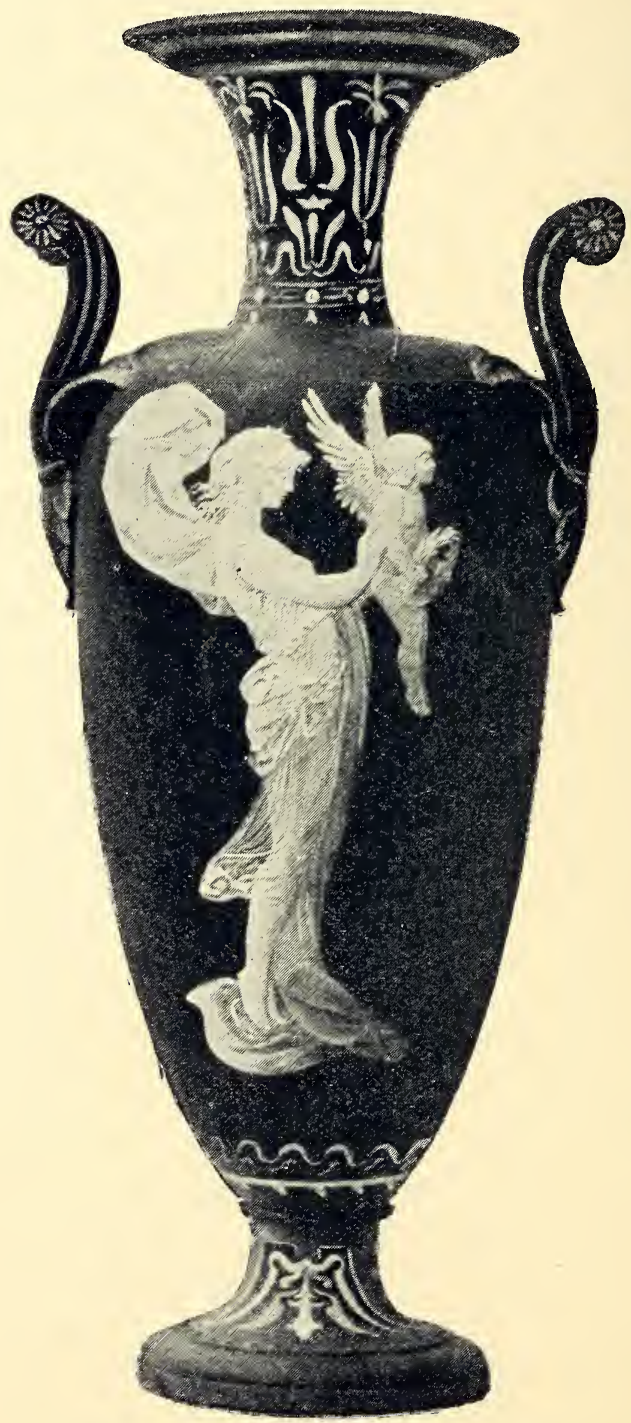

VASE by Solon. (See "Pâte-sur-Pâte," page 48 .) 


\title{
Staffordshire.
}

\author{
JosIAH WEDGWOOD.
}

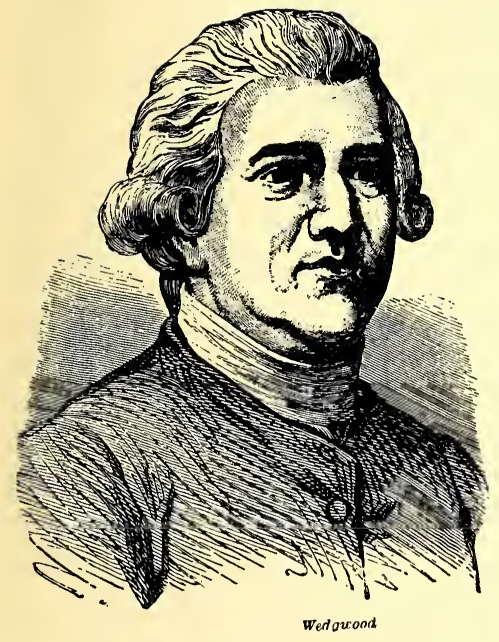

No potter has had more worthy historians than Josiah Wedgwood. Meteyard, Jewitt and Smiles have each written con amore. The story of his life has been told so well, so often, and with such a measure of appreciation that the present sketch fulfills its purpose, if it incites the reader to a closer acquaintance with the subject. There had been Wedgwoods before him in the pottery business, and more than one has left his imprints on the sands of time. The first example of pottery bearing the name of Wedgwood is a puzzle-jug of brown ware, the name "John Wedgwood, 1691," being incised in the clay. John and Thomas Wedgwood in 1740 were experimenting with and testing the qualities of various clays, and were the first potters in Staffordshire who had a tiled roof to their works, all having hitherto been straw-thatched. Dr. Thomas Wedgwood was looked upon as the leading potter of Burslem, and made good agate ware and pieces in the style of the Elers. Aaron Wedgwood discovered that "C. C." could be made white by adding zaffre to the glaze, and he was the first to glaze ware by immersion.

Josiah Wedgwood was born at Burslem, July 12, 1730, the youngest of thirteen children. When his father, Thomas Wedgwood, died, in 1739, Josiah was taken away from school, so that it was entirely by his own efforts he acquired the education that he possessed later in ife. Shortly afterwards he was employed in his brother's factory, and early developed a taste for modeling, and in his fourteenth year was apprenticed to him as a thrower. Three years previously, in 1741, he had a virulent attack of small-pox, which left a distressing pain and weakness in his right knee, and this interfered so much with his work that he was obliged to give up the thrower's bench and become a moulder. Much of his time was spent in experimenting with different clays, and when, in 1749, his apprenticeship ended, his brother was so opposed to his "flights of fancy" that he declined to take him as a partner. He continued to work at the bench, studying hard in the meantime, and when he was twenty-two he entered into partnership with John Harrison, of Cliff Bank, near Stoke. Two years later, Harrison, not satisfied with his share of the profits, withdrew, and the works were shortly afterwards pulled down. In 1754, Wedgwood formed a new partnership, this time with Thomas Whieldon, of Fenton, one of the most eminent potters of the day, and the man above all others calculated to encourage Wedgwood in his efforts to advance their art. He produced a beautiful green glaze for earthenware, and an imitation of precious stones applied to small articles for mounting. His knee so troubled him as to necessitate 
frequent absences from the factory, and he was obliged to confide his secret to others, and in a short time green glaze was largely made at other factories. His investigations in other directions he steadily and persistently pursued, never content with what he had accomplished, striving always after new bodies and glazes, and to advance the art to which he had devoted himself. At the expiration of the term of partnership in 1759 , Whieldon retired with a considerable fortune. Wedgwood returned to Burslem and rented part of the Ivy House Works, where he made his own models, saw to the firing and superintended everything. Here, amongst other things, he made perforated dessert-plates and white medallions, and had soon to considerably increase his force and enlarge his works. His fertile brain was constantly at work, either on new mixtures, improving the tools used in manufacturing, or on plans for bettering the means of communication with the outside world, for the want of this latter was a serious obstacle in the development of its trade, which, thanks to his efforts, had now considerably increased. The lanes leading out of Burslem were narrow and tortuous, and on account of their roughness the horses laden with clay or pottery frequently fell down. Slow progress only could be made, the expense of transportation was necessarily great, and vexatious delays were more the rule than the exception. Mainly owing to his strenuous exertions, these lanes and bye-paths gradually gave place to good highways, and later, the cutting of the Grand Trunk Canal, of which he turned the first sod, made communication easier and cheaper. But this was the result of the hardest kind of work and took years to accomplish. In 1763 Wedgwood greatly improved the quality of table earthenware, and the Queen, to express her approval of a service he presented to her, ordered it to be called Queensware. It quickly came into general use, and large quantities were sent to Saâler and Green, of Liverpool, to be printed; but the expense and loss on the double journey were too inconvenient, and he acquired the right to use the process himself. About this time, in a journey to Liverpool, Wedgwood's knee was crushed against the wheel of a cart, inflammation set in, and he was confined to his room in Liverpool for some time. It was then he made the acquaintance of his future partner Bentley, whom he appointed as his Liverpool agent. A great friendship sprung up between the two, a friendship delightful to contemplate between the inventive, self-educated potter, and the polished man of the world, educated and refined, a contributer to the leading journals of the day, whose courtly manners gave an added charm to Wedgwoor's triumphs. Henceforth Wedgwood took no important step without consulting him, and shortly afterwards a partnership was formed between them, so far as the ornamental part of the work was concerned, Bentley residing in London and having full charge of the showrooms, and also the works which Wedgwood started at Chelsea, where a number of modelers and artists were employed. (Plate 4, fig. 20). Wedgwood was the first to adapt the turning-lathe to the manufacture of pottery, and by its aid his copies of antique vases, which had already acquired much notice, were vastly improved. One of his great ambitions was to revive the classical Greek works and thanks to the Royal patronage bestowed upon him, many eminent scholars and owners of precious antiques rendered him important help. Models were supplied him, and these he reproduced with so much fidelity, and with such an appreciation of their beauty that a great demand sprang up for them. He was kept busy day and night; a large export trade was developed; artists of ability flocked to Burslem, and not only 
Wedgwood, but other factories, whose owners had reaped the benefit of his experi. ments, grew inadequate $\uparrow \sim$ meet the demand; the population largely increased and a period of prosperity reigned. Not being able to find suitable premises in Burslem, he purchased the Ridgehouse estate, two miles distant, and erected there a village and factory that he christened Etruria. Wedgwood married a distant connection, Sarah Wedgwood, January 29, 1764, and she was in all respects all that man could desire. Handsome and finely educated, she entered heartily into her husband's plans, learned his cipher, so as to relieve him at his work, nursed him with unfailing tenderness, cheered and encouraged him, and proved herself one of the best and tenderest of wives. His leg still troubled him, and his eyes also constantly failed him, but his dauntless courage never forsook him, and he not only continued but enlarged his studies. Four years afterward his leg was amputated, and henceforth he walked through life with a wooden leg; and surely never wooden leg has left such echoes down the corridors of time. The doctors could afford him little relief for his eyes, and we find him urging Bentley to come to Etruria and acquaint himself with its secrets, so that he could at any time continue the works. Wedgwood's opposition to the extension of Cookworthy's patent for the manufacture of china, applied for in 1753, by Richard Champion, to whom Cookworthy had transferred it, has been severely criticised as factious in the extreme; but when it is remembered that of all Wedgwood's inventions and improvements he only patented one unimportant one, it is evident that he was prompted only by a desire for the general good, and was strong in his convictions that if the raw materials were thrown open to all : " a variety of experienced hands would probably produce more advantage to the Nation in a few years than they would ever do when confined to one manufactory, however skillful the director might be." And though the Lords and Commons said "No," Wedgwood was undoubtedly right. His discovery of "Jasper," gave additional impetus to the Etruria works, but cobalt, by which the body was stained, was an expensive material, and, in 1777 , he invented a jasper dip. Jasper is composed of sulphate and carbonate of baryta in combination with flint and clay, stained with oxide of cobalt. It has the peculiar property of receiving through its whole substance a metallic coloring matter, which no other body, ancient or modern, possesses. The secret of its manufacture was preserved at Etruria for about twelve years. Flaxman and other artists furnished designs for bas-reliefs, cameos, etc., and the highest possible standard of excellence was insisted on and maintained. Whenever a piece that did not come up to his standard of excellence caught Wedgwood's eye in his peregrinations through the works, to make assurance doubly sure he would smash it with the cane he was in the enforced habit of carrying. His crowning achievement in Jasper, the copying of the Portland vase, a full account of which is given elsewhere, is so well known as to need but passing notice here, except perhaps to record the date, 1790 .

\footnotetext{
"Bid mortality rejoice or mourn

O'er the fine form of Portland's mystic urn."-Darwin.
}

It is by Jasper that Wedgwood's name is best known, though, in the course of his busy life, he found time to perfect an Egyptian black body ; improve the quality of table earthenware ; make a cane-colored biscuit and terra cotta, and a hard porcelain for crucibles; invent an instrument for measuring the heat during the firing 
of the ware ; make a journey to Cornwall to investigate the clays found there, and another to Meissen with a view of purchasing and working the Royal works there. He was also an enthusiastic and liberal supporter of slavery abolition, was treasurer of the Grand Trunk Canal and a member of many learned societies. He died January 3, 1775, aged sixty-five, and was buried in the old parish Church, at Stoke. Five years previously he had taken into partnership his three sons, John, Josiah and Thomas, and his nephew Byerley. John and Thomas retired, and the firm became Josiah Wedgwood, Son \& Byerley.

His influence on English pottery can hardly be overestimated. Nearly always racked with pain, at times almost blind, with only the most rudimentary education, by his genius, his incomparable patience, with the most marvellous rapidity of conception and adaptability he recovered much that was deemed lost, and added new standards of excellence in ceramics that will endure for all time. But if you would know more of this wonderful man, of his home-life, of his love and friendship, of his early struggles, his care for his workmen and of his ultimate triumph, and care but little for the technicalities of his art, read Smile's story of his life.

One is apt to grow enthusiastic over such a subject, but in forming an estimate of Wedgwood's influence on English Ceramics we must be careful not to let our enthusiasm outweigh our judgment. And in this consideration, John Dwight, of Fulham, is an important factor. So, too, are Whieldon and Astbury. The life of the latter, if it is ever written, will be of absorbing interest and tinged with romance for which I know no parallel in industrial biography.

After the death of Wedgwood the management developed upon Thomas Byerley, who died in 1810. In 1823 the third Josiah Wedgwood became a partner, and four years later his brother Francis was admitted, and the firm name was changed to Josiah Wedgwood \& Sons. In 1809 the manufacture of china was commenced, only however to be abandoned nine or ten years later. About ten years ago it was revived. John Boyle and Robert Brown were both partners for a few years, the firm eventually consisting of the present members, sons of Francis Wedgwood, Godfrey, Clemence and Lawrence. In 1860, Majolica was added to the firm's productions, and in 1865 was revived the solid jasper body.

Lessore, an exhibitor in the Paris Salon of 1831, and an artist of great ability, disgusted with the divisions caused amongst the Sèvres artists by his originality in decorating pottery, came to England in 1858, and after being a short time at Mintons, settled down at Wedgwoods'. His works were highly prized on account of their originality and breadth of treatment, he being the first artist to employ free brush work on pottery, paintings having hitherto been mostly in miniature and very highly finished. He died in 1876 .

Mr. Thomas Allen about the same year was engaged as principal figure painter and Art Director. $\mathrm{He}$ is a talented artist of original conception and artistic execution, careful in drawing and composition and has produced a number of important pieces, of which one, "Orpheus and Eurydice," dwells particularly in my memory.

For the rest, old models, old engravings and old methods are paramount at Etruria. (See Plate 3, Fig. 18.)

There are two monuments to Josiah Wedgwood: a statue in bronze in the Station Square at Stoke, and the more important one at Burslem, the Wedgwood Memorial Institute. 


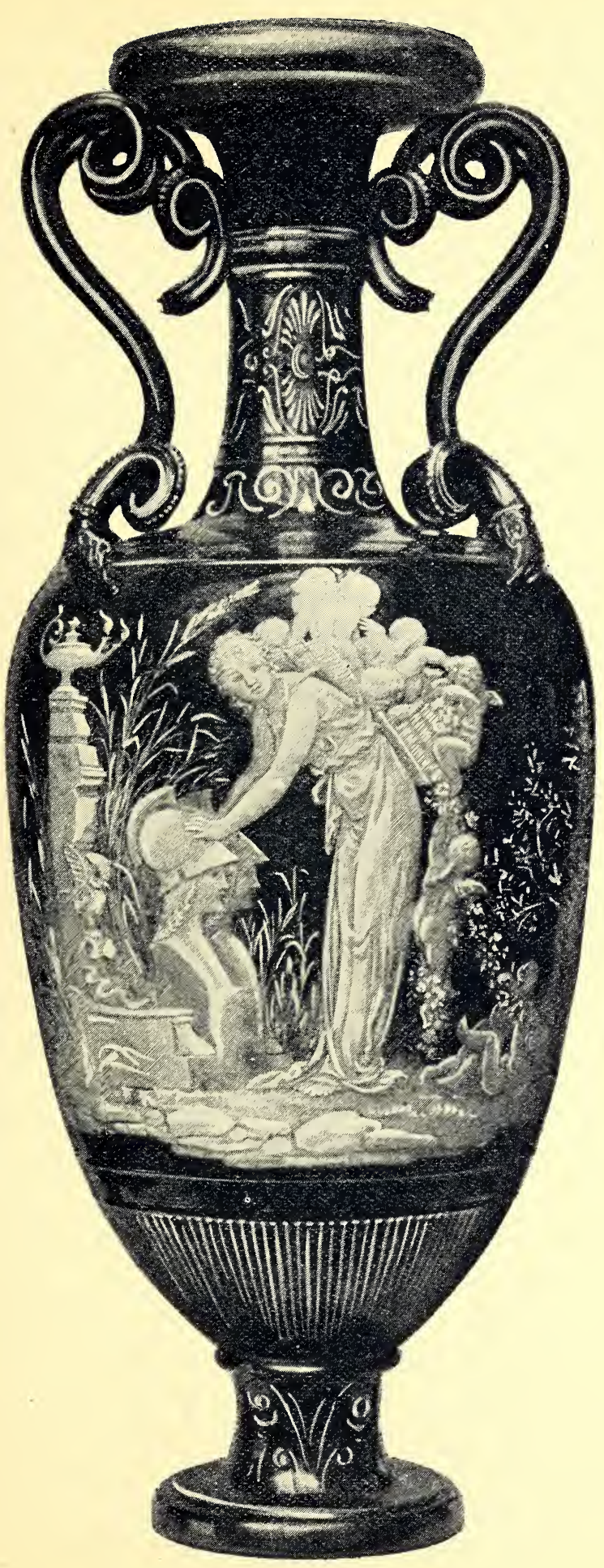




\section{Mintons.}

$\mathrm{T}^{\mathrm{s}}$

EN years before the death of Wedgwood there was working for the Spode factory an engraver named Thomas Minton, who was destined to start an industry the beauty and extent of which he probably never dreamed of. In 1788 he erected at Stoke a house and works on the site which has since become so celebrated. Wedgwood was then in his zenith. Spode and the Ridg. ways had already obtained some celebrity for earthenware, while in china, Derby, Worcester and Caughley divided the honors. In 1790 Thomas Minton entered iuto partnership with Joseph Poulson, who had been manager for Spode's, and they were joined in 1793 by Mr. Pownall, who retired in 1800. Poulson died in 1809, leaving Thomas Minton to conduct the business alone. Up to 1798 earthenware alone had been made, and the staple of the business consisted of white ware ornamented with blue, in imitation of Nankin, and the abilities and experience of Thomas Minton as an engraver had acquired for the firm a good commercial reputation. In 1798 the manufacture of semi-transparent china was commenced, but it was not a success and was abandoned in 1811.

Thomas Minton had two sons, Thomas Webb and Herbert, the latter born Feb. 4, 1793. Both were admitted into partnership with their father in 1817, Thomas W. retiring in 1821, to enter the church; and Herbert, owing to family circumstances, nominally retiring from 1823 to 1831, when on his father's death he succeeded to the business. He shortly afterwards admitted as a partner Mr. John Boyle, who remained for about five years and then joined the firm of Wedgwood, his place being taken by Mr. Minton's nephew, Mr. Michael Daintry Hollins, a gentleman whose genius and skill as a chemist have not received the recognition they deserve, and but for whom Minton's triumphs would probably never have reached the perfection they attained, though to his credit be it said that Herbert Minton himself was always ready to acknowledge his great obligations. In its last phase the firm for the ten years preceding his death consisted of Mr. Minton and his two nephews, Mr. Hollins and Mr. Colin Minton Campbell.

No better estimate of the character of Herbert Minton and his influence on ceramic art is to be found than the eulogy pronounced by the eminent critic, Mr. Digby Wyatt, who said: “Mr. Herbert Minton's industrial career as assistant and principal, may be looked upon as extending over some fifty years of the present century, a period hitherto without a rival in the history of civilization-one of social progress and commercial development, of restless energy of thought and untiring labor, crowned by innumerable conquests of mind over matter. Of that apparently inexhaustible activity, intellectual and physical, which has formed the dominant characteristic of the past half century, Mr. Minton offered a perfect type, and it was rather through this element than any other that his influence was so powerful as a stimulant and fertilizer. Neither a man of profound research nor an educated artist, neither an economist nor an inventor, by courage and ceaseless energy he brought to bear upon the creation of his ultimately colossal business, such a combination of science, art, organization and invention as can be paralleled only by that rare union of qualities which impressed the stamp of genius upon his 
great predecessor, Josiah Wedgwood. A clear head, a strong body, rare powers of endurance and observation, a cool judgment, in spite of a singularly sanguine temperament, a kindly nature and genial manner, were the leading characteristics of Mr. Minton; and with such natural gifts, and an amount of perseverance to which I know no parallel in history (excepting, perhaps, that displayed by the celebrated potter, Bernard Palissy), he was enabled to benefit his country, while building up his own fortune, and to do credit to the age in which he was born, thereby winning lasting honor for his memory."

At the beginning of the eighteenth century the Minton works gave employment to just about fifty hands. At Herbert Minton's death upwards of fifteen hundred were in active employment. It is computed that in 1840, the value of English ceramic exports amounted only to about $£ 573,000$, while in 1858 they were about two and a half million pounds sterling, and undoubtedly to this large increase $\mathrm{Mr}$. Minton's activity largely contributed.

In 1848 Minton was fortunate enough to secure the services of Mr. Leon Arnoux, a gentleman who had long enjoyed the reputation of being, perhaps, more profoundly versed in the mysteries of ceramic manufacture than any other savant in France. Engaged originally as the potter of the establishment, he displayed such a thoroughly artistic training that he was reluctantly induced to combine with it the post of art director, a reluctance difficult to understand, as it was impossible to overrate his eminent fitness for the position. Mr. Arnoux, with great heartiness, entered into his principal's views, and too large a measure of praise cannot be allotted to him for his unrivaled skill and artistic execution. He might fitly be compared to the steam that drove the machinery. Death has but a year or two ago severed his connection with the firm, and it may be of interest here to quote his vindication of the peculiar class of body of which English china is made.

Mr. Arnoux says: "Certain very particular amateurs bring an objection against British porcelain, and say that, as it has phosphate of lime for its base instead of being composed entirely of pate frittee, it has no claim to be called pate tendre. This objection appears to be nearly groundless. The chief beauty of the pate tendre consists of the complete amalgamation of the colors with the glaze, and also in its capability of receiving certain tints which cannot be applied to any other kind of porcelain, such as turquoise blue, emerald green and rose du Barry. If our porcelain combines these qualities in the highest degree-if its whiteness and transparency have been increased by the employment of phosphate of lime, who has any reason to complain? Our productions possess all the advantages of the old porcelain, and have, in addition, several accessory ones. We shall therefore do wisely to uphold this manufacture, since it brings us nearer to perfection."

In 1821 the manufacture of china was resumed, the earlier patterns being imitations and adaptations from old Derby china. A few years later, when the Derby factory began to decline, many of the workmen joined the Minton works, and the decorations rapidly improved. Bancroft, Steel and Hancock were among the principal fruit and flower painters; John Simpson was the principal figure painter from 1837 to 1847 and Samuel Bourne was designer-in-chief. He was succeeded by M. Jeannest, an industrial artist of great ability. M. Carrier-now Carrier-Belleusewas soon after the chief modeler, and it is a tribute to his skill and the grace with which he invested his productions that they have remained to this day in popular 
demand. Nor should the name of M. Protat be omitted. The quality of the body, the beauty of the glaze, were both improved, and colors, before but imperfectly realized, were produced in great purity. The jurors' award of the exhibition of 1851 was a fitting acknowledgment of the credit due to Mr. Minton for the progress made in the ceramic art. (See Plate 4, Figs. 18, 19.)

In 1849 , with the assistance of Mr. Arnoux, Mr. Minton resumed the attempt to make hard porcelain, and succeeded so well that in 1851 vessels for the laboratory were exhibited and pronounced by experts as superior to those of Meissen and Berlin, which had formerly been imported in large quantities, about $£ 60,000$ worth annually. About the same time the manufacture of Parian was commenced, of which we have spoken freely in the article under that heading.

But the crowning glory of his life and works was the revival of the manufacture of encaustic tiles. Mr. S.Wright some years previously had taken out a patent for their manufacture as an original invention, but only such specimens were obtained as encouraged the hope that success might ultimately be obtained. From him Mr. Minton purchased the patent and set to work with a fixed determination to succeed. He had then to solve the problem of firing the various colored clays so as to insure perfect uniformity of color throughout the body, to so temper them as to prevent and correct the irregularities of shrinkage, induced by the different materials used to produce the desired colors, and to extend the range of colors used by the potters of the middle ages. After months of patient research, of failure and disappointment, success eventually crowned his efforts, and Minton tiles are known and used the whole world over. Many difficulties were encountered, difficulties of too technical a character to enumerate here, but Mr. Minton's dogged determination, aided by the valuable service and knowledge of both Mr. Arnoux and Mr. M. D. Hollins, triumphed over all, and the honors are fairly divided among them. Toward the close of the term for which the patent had been taken out, Mr. Minton allowed the Worcester Porcelain Company to manufacture encaustic tiles under a license, but the Worcester clays were unsuitable and they abandoned the manufacture, and were succeeded by Maw \& Co., who shortly after removed to Broseley.

About 1840 Mr. Prosser patented a process for solidifying china clay in dry powder by subjecting it to great pressure in iron molds, obtaining a substance of extraordinary density and evenness of texture. This Minton purchased and used for the manufacture of buttons, of which exceedingly large quantities were produced. Later, it was applied to the manufacture of tesseræ, for the formation of pavements, in imitation of those of the ancients.

Some specimens of majolica ware, which had formed part of the collection of the Duke of Buckingham, coming into the hands of Mr. Minton, he determined to reproduce them, and with what success is well known. For fifteen years he was the only manufacturer of majolica in England. It must not be understood that Mr. Minton was alone in the race. He had keen competitors in Copeland, Ridgway, the Coalport Works and others. Every faculty had to be exercised, every energy stimulated to keep abreast, but the competition was a generous one.

It was not alone as a manufacturer that Herbert Minton has claims upon our gratitude. He did much to ameliorate the condition of his work people. By his kindly intercourse with them he endeared himself to their hearts; he built 
and endowed a church and schools for their benefit, and his genial nature when in contact with them lightened their daily burden. His example of perseverance was an incentive to them all, and no matter what success he achieved his energies never relaxed; there could be but one watchword for him, "Forward."

A dessert service exhibited in London in 1851 was deemed by the Queen a fitting present to the Emperor of Austria, Mr. Minton himself making the presentation on her behalf. At the court of this monarch he met with a very flattering reception. At the American exhibition of 1853 he followed up his previous triumphs, and took the opportunity of making a tour through the United States. At the Paris exhibition of 1855 he had conferred upon him the Cross of the Legion of Honor.

He died April 1, 1858, and was succeeded by his nephews, Mr. Colin Minton Campbell and Mr. Michael Daintry Hollins.

Having laid the foundations and partially constructed the edifice, Herbert Minton was fortunate to have two such worthy successors as Messrs. Campbell and Hollins. The latter was an excellent chemist, whilst Mr. Campbell had the peculiar faculty of being always a little ahead of public taste and as a consequence appeared to lead it. The encaustic tile business was run as a separate concern under the style of Minton, Hollins \& Co., and when these gentlemen dissolved partnership in 1867, Mr. Hollins continued that part of the business. Mr. Campbell retained control of the remainder of the business, changing the style from "Herbert Minton \& Co." to "Minton \& Co.," and shortly afterwards admitting into partnership his cousins, T. W. and Herbert Minton. After Mr. Campbell's death, in 1883 , the business was transformed to a limited liability company, and is now styled "Mintons, Limited."

In 1870 they patented the invention of mosaic painting, by which the painting is indelibly produced upon tesseræ, which may be fitted either to a curved or flat surface. Every touch of the artist is preserved and it is perfectly impervious to the effect of either weather, time or climate. The stairway at the South Kensington Museum contains some excellent specimens of this work, finely executed by Thomas Allen.

At the various exhibitions fresh honors accrued to them, and their display at Philadelphia came as a revelation to Americans, who had long been satisfied with cheap and inartistic White Granite. Of the artists employed Thos. Allen was the principal figure painter, Hy. Mitchell for landscape and animal subjects, R. Pilsbury and Thomas Simpson for flowers, Charles Toft and Simon Birks, modelers. Mr. L. Jahn was also a clever figure painter and was afterwards art director for Brownfields, Mr. Thomas Allen accepting a similar position in the historic house of Wedgwoods. The Mr. Joseph Stringer, so frequently quoted by Mr. L. Jewett, was the correspondent, a kind and genial gentleman, with whom the writer was in close intercourse for a number of years. He had been the editor of a newspaper at Stafford, and had aspirations to do for Minton what Jewitt had done for Wedgwood, but death took him before his loving task was completed.

In 1870 Mintons erected an art studio at Kensington, and associated with it were such artists as H. S. Marks, A. R. A., W. H. Coleman, Colonel Stuart Wortly and others.

After the Franco-German war a large number of artists from both countries 
came to England and many found employment with Mintons. Amongst them were M. Boullemier, a painter of very dainty figure subjects; M. Mussill, a bird and flower painter of great force and originality; Mr. Palm, an adept in the use of colored golds, and last, but by no means least, M. Solon, the pâte-sur-pâte artist,

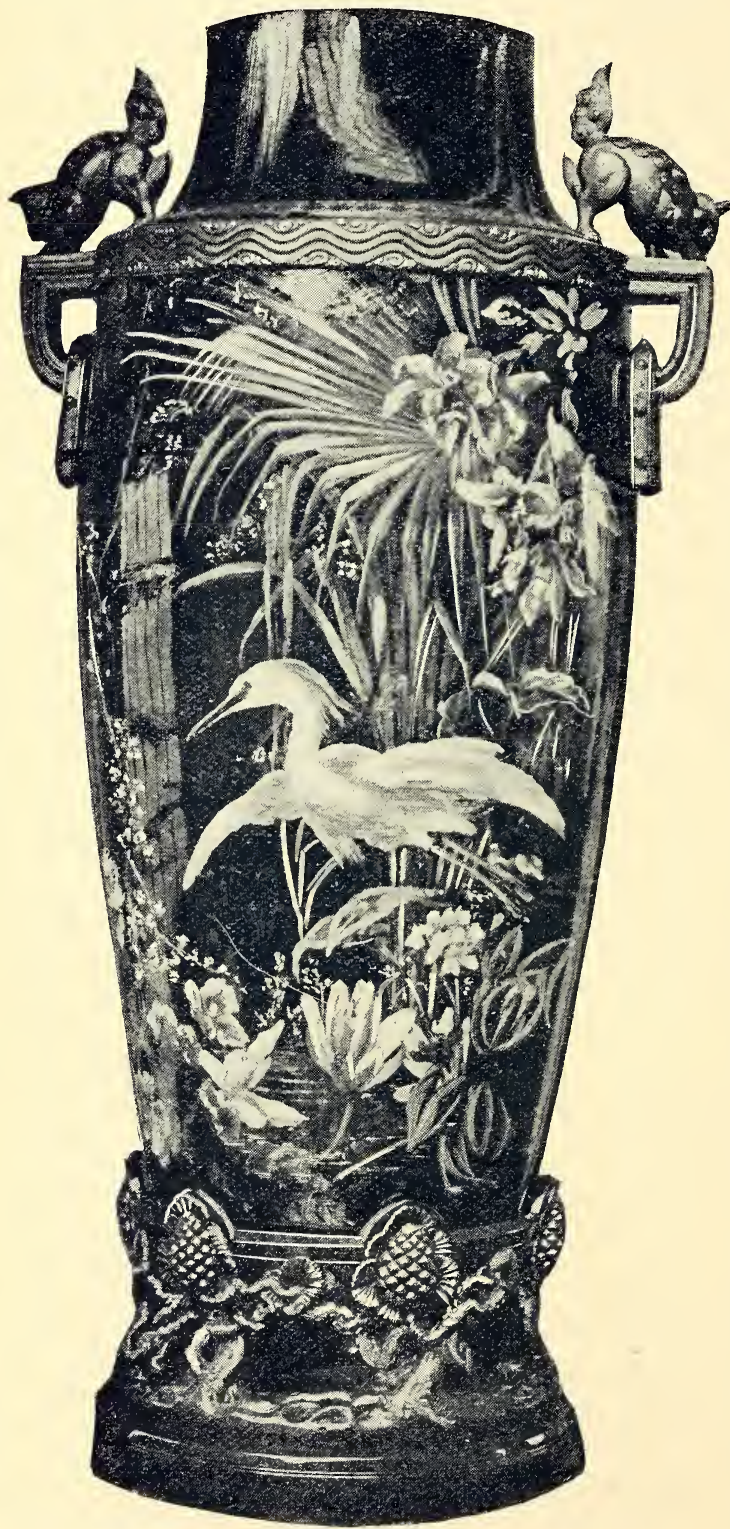

Vase by Mussill. whose reputation needs no endorsement here. (See illustration page 17.)

The vase shown in our illustration, painted by Mussill in underglaze colors, is nearly six feet high, and was purchased by Messrs. Tiffany \& Co.

Mr. H. Minton Robinson is chairman of the company ; Mr. George Leason has long been the practical potter, an onerous position he adequately fills. After the death of Mr. Arnoux, Mr. Jahn was selected as Art Director. With such an aggregation of talent, with every improvement and facility that human ingenuity can devise, it is not surprising that, in face of the vigorous efforts of competitors, the work of building the edifice steadily continues, and if no precious secrets in ceramics have been added, all that is meritorious in the old has been duplicated ; the standard of excellence is maintained and many graceful thoughts and lofty fancies find expression, sometimes in enamels that rival those of the Chinese; sometimes in the poetical productions of M. Solon, or in evidences of technique and craftsmanship creditable alike to the craftsman and the firm. (See Plate 2, Fig. 12.) 


\section{Spode $=$ Copeland .}

$\mathrm{T}$

HOMAS WHIELDON was one of the best known of the old Staffordshire Potters. Apprenticed to him was a youth named Josiah Spode, who, in 1770 started in business for himself at the works in Stoke previously carried on by Turner \& Banks. William Copeland, a traveler, made the acquaintance of Spode and offered to sell his goods. The enterprise was very successful and a warehouse was taken in London. Trade increased and Copeland became a partner, managing the London business, whilst Spode devoted himself entirely to the manufactory. They made an excellent earthenware body, and in 1800 commenced making porcelain. This was under the second Josiah Spode. Mr. Prime credits Spode with the introduction of bone ash in the composition of a china body. Simeon Shaw, in his "Chemistry of Pottery," ascribes it to William Littler. Mr. A. H. Church, in his "English Porcelain," unhesitatingly ascribes it to the Bow factory. The first patent taken out in 1744 gives as the ingredients : one part of potash, one part of sand or flint, and from one to four parts of porcelain clay called unaker, from the Cherokee Territory, North America. In the second patent the unaker is replaced by other materials. Two parts Virgin earth, produced by the calcination of certain animals, vegetables and fossils, are directed to be mixed with one part of flint or sand and then fritted, then of this frit two parts are taken and mixed with one part of pipe clay. Analysis of the fragments discovered on the site of the Bow works, show 44.3 per cent. of the bone ash or phosphate of lime in their composition. Analysis of Chelsea, Worcester and Caughley china made during the second half of the eighteenth century prove however that the employment of bone ash was very widely extended about the year 1760. In "Handmaid of the Arts," published in 1758, calcined bones are given as one of the ingredients for making a true china.

Five years later Spode introduced an opaque porcelain, known as "Ironstone China," and its superiority over the ordinary table earthenware won it instant success and a host of imitators. Three generations of Spodes, all named Josiah, and three generations of Copelands, have always constituted the firm and none others, with the exception of Thomas Garrett, who was a member from 1833 to 1847. The Spodes died in 1797,1827 and 1829 respectively. The original William Copeland died in 1826, and his son, W. T. Copeland, succeeded him. He was familiarly and lovingly spoken of as "the old Alderman." He sat in Parliament for Coleraine from 1828 to 1832, and for Stoke-upon-Trent from 1832 to 1852, when he lost his seat, but was re-elected in 1857, and sat until 1865. From 1847 to 1867 he conducted the business as sole partner, and then admitted his four sons, who now carry on the business, into partnership. Their earthenware has always been very popular, the glaze of fine texture and of ivory tint, which has rather interfered with its success here, though why the harsh coldness of white wares should be preferred, I am at a loss to imagine, especially in conjunction with the now fashionable blue decorations. In celebration of its centenary Messrs. Copeland last year revived Spode's Tower pattern in zaffres blue, and it bids fair to duplicate the success it achieved a hundred years ago. This pattern was originally engraved 
by Daniel Greatbatch, who died at an advanced age some forty years ago. It is a

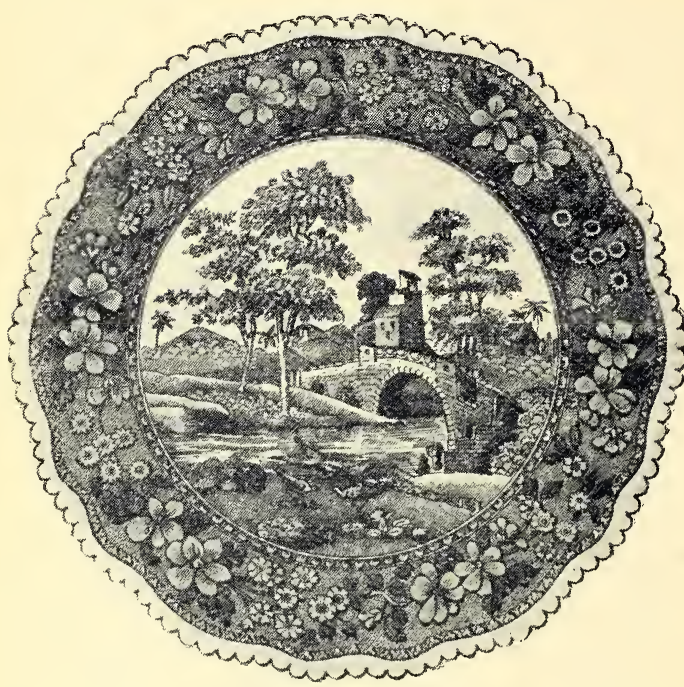
very interesting memento of a period of which we have none too full information.

In tiles Messrs. Copeland produced some truly magnificent friezes, and by granulating the surface, very broad and effective results are obtained.

The replica of an old Chelsea dinner set loaned to them by the Grand Duchess of MecklenburgStrelitz was successfully accomplished, the imitation of the paste and glaze being excellent. The first production of Parian, a short account of which appears elsewhere, is to be credited to this firm. This was fiercely contested at the time by Mintons, who were also experimenting in the same direction and issued samples almost simultaneously with Copelands, but the weight of evidence seems in favor of the latter firm.

In jeweled china, Messrs. Copeland have been very successful, differing from Sèvres, and superior to it from a ceramic standpoint. These few examples will give an idea as to the diversity of the firm's productions. It is impossible to write any account of Copeland's without some reference to the veteran flower painter, Mr. C. F. Hürten, whose magnificent and life-like flower-pieces have contributed in no little measure to the success of the firm. Nor of Mr. R. F. Abraham, a graduate from the Coalport Works, who long filled the position of Art Director, and whose recent death the writer, amongst the humblest of his friends, has not ceased to mourn. Mr. Lucien Besche, a versatile figure painter, achieved some of his most successful work here. Mr. Robert Abraham and Mr. J. Hewitt, both figure painters and brilliant colorists, were also employed. Mr. W. Yale was, and I hope is, the leading landscape artist, his studies in monochrome being particularly successful. Mr. Samuel Alcock is the present chief figure painter, his work being characterized by excellent drawing (Plate 4, figs. 16 and 17, and Plate 2, fig. 16,) and very careful and miniature-like finish. 


\section{Parian.}

$\mathrm{P}$

ARIAN was first made by Copeland and Sons, Stoke-upon-Trent, and exhibited by them at the London Exhibition of 1851. It is an imitation of the marble of Paros, from which it (probably) derives its name. It is composed of three-fifths of China-stone and two of feldspar. It is non-plastic and therefore cannot be modeled. It is therefore made into slip and poured into a plaster mould. The plaster absorbs the water and leaves the solid clay adhering to the sides of the mould. It is used principally for statuary, generally cast in several pieces and joined together before firing, by means of slip. A figure of Fanny Ellsler, the dancer, and some other pieces have elaborate lace trimming, as delicate and cobwebby in appearance as the real article. It is in fact real lace which has been dipped in slip and draped on the figure, the fabric itself being consumed in the firing. This process was, for a long time, a specialty of Minton and Worcester, but latterly it has been extensively used in a cheap form by other factories. The Royal Worcester Co. also produce some excellent specimens of Parian Statuary, and amongst the cheaper productions, Robinson \& Leadbeater make the best. Large quantities of white Parian are sent to France and Germany, and there coarsely colored, destroying whatever beauty they originally had.

\section{Davenport.}

THN DAVENPORT'S first connection with the pottery business was as partner with Mr. Woolf, who had a manufactory adjoining that of Mintons', at Stoke. During a business trip to France, he seems to have made himself acquainted with all the details of the manufacture of china, and after the dissolution of the partnership, in 1794, he acquired the works at Longport of John Brindley, brother of the celebrated engineer, James Brindley. Benefitting by the knowledge he had acquired in France, and recognizing that the china made in England was of but poor quality - for that produced by Wedgwood by no means equalled his other productions-he applied himself assiduously to its manufacture, and soon produced china of remarkable transparency, which some amateurs do not hesitate to place in the first rank, so far as its texture is concerned. For eighty years it was made from the same formula.

In 1801 Mr. Davenport added glass making to his business, and this, like all he attempted, was of the very finest quality, and had a deservedly high reputation. Four years later he added the staining and painting of glass windows for churches, etc., with Fuseli, afterwards President of the Royal Academy, at the head of a large number of painters. The Royal Crown was added to the trademark in 1806, after executing an important commission for George IV.

Mr. Davenport represented the borough of Stoke-upon-Trent in Parliament for a number of years. He died in 1834, his two sons, Henry and William, continuing the business. The former was killed in the hunting field, and the latter died in 1869 , and was succeeded by his son. But he had inherited neither his grandfather's business acumen, nor skill as a potter. The works gradually decayed and were finally brought to the hammer, (Plate 4, figs. 7 and 8.) The moulds and patterns wore dispersed and it is interesting to note that Messrs. Doulton have just revived a Davenport pattern in dark blue from their original moulds and engravings. 


\section{Cauldon $($ Brown=Westhead Moore \& Co).}

$\mathrm{T}^{\mathrm{n}}$

HE Cauldon Place factory was started in 1794 by Job Ridgway, the father of John and William Ridgway, and carried on by him and them until his death in 1814 . In 1794 blue printed ware was made in addition to a species of stone ware of good quality. Soon after 1815, John Ridgway introduced a bone china, with a rich glaze, well adapted for the use of the richest colors. In 1822 he made a voyage to America-the passage occupied thirty-three daysand as a result a good trade with this country resulted. (Plate 3, Figs. 1, 2 and 3). About this time the brothers dissolved partnership and William opened another factory, and was later the prircipal partner in several others. Parian and sanitary ware were added to the products of the Cauldon works, and under John Ridgway's energetic management, royal and more substantial honors were showered on the firm. He continued with various partners to conduct the works until 1859 and died one year later.

He was held in the highest estimation as a man of unswerving integrity, and his memory is perpetuated in the Ridgway Memorial Church. After his death the business was bought by W. Bates, T. C. Brown-Westhead and W. Moore, but Mr. Bates retired in a very short time. Mr. Moore died in 1836 and the manufacturing part developed on his brother James, who was admitted a partner in 1875 . He died in 1881 and his nephew, Mr. F. T. Moore, took charge of the potting department. Mr. Brown-Westhead died in 1882 and Mr. W. B. Moore and his brother continued the works. Their exhibits at Philadelphia in 1876, at Paris in 1889 and at Chicago were of the greatest beauty and stamped them as formidable competitors with more well known firms. Respected for their progressiveness, their productions equal to the best, they have, in a few years, made a demand for their artistic wares that taxes the capabilities of the factory to the utmost. There is every indication that "Cauldon" will be the ware of the future. Certainly, if the future sees the same amount of progress that has characterized the past, there is a brilliant one in store for them. Their manufactures range from sanitary ware to the finest china, and visitors to the Chicago Exhibition will not readily forget the exquisite display they made there. (Plate 3, Fig. 4, and Plate 2, Fig. 29.) 


\section{American Historical Earthenware.}

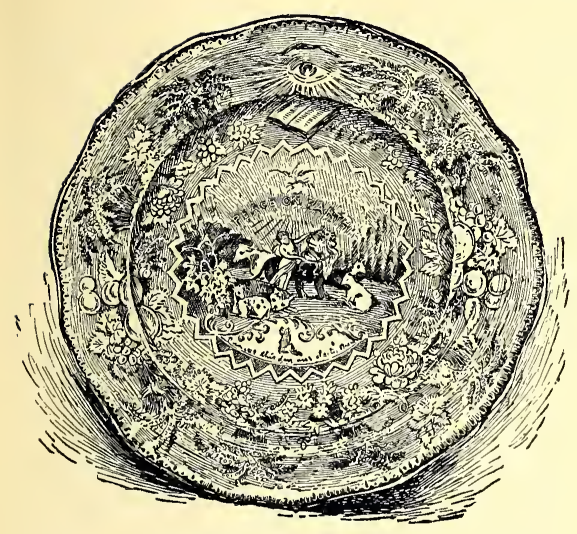

Millenium Plate.

DURING the early part of this century and for a period of twenty or thirty years, large quantities of earthenware were imported here from England, of a patriotic and national character which, although now eagerly sought after by collectors, seem to have been overlooked by English writers on ceramics. Mr. Prime briefly notices them. This ware was generally decorated in blue underglaze with American views and patriotic designs of American heroes. In many cases the engraving is most excellent and the color deep and rich.

Lafayette, Jefferson, Washington and De Witt Clinton figure frequently. The opening of the Erie Canal has six different views. There are upwards of thirty of Boston, twenty of New York and twenty-five of Philadelphia and vicinity. A very popular design, made by Clews, had the names of the different States in a scroll border. (Plate 1, Fig. 18.) The best of these were made by Wood, Steven son, Clews, Stubbs and Ridgway, and it is instructive to compare the great similarity of their production with the variety made by their successors.

Enoch Wood commenced bus. iness at Burslem, about 1750 , as a manufacturer of salt glaze stone ware, and towards the close of the century he admitted his son Enoch - known as "the father of the potteries"-into parinership and the firm name was E. Wood \& Son. Under the son's management earthen ware of a much improved quality was made and a large business, principally with this country, was

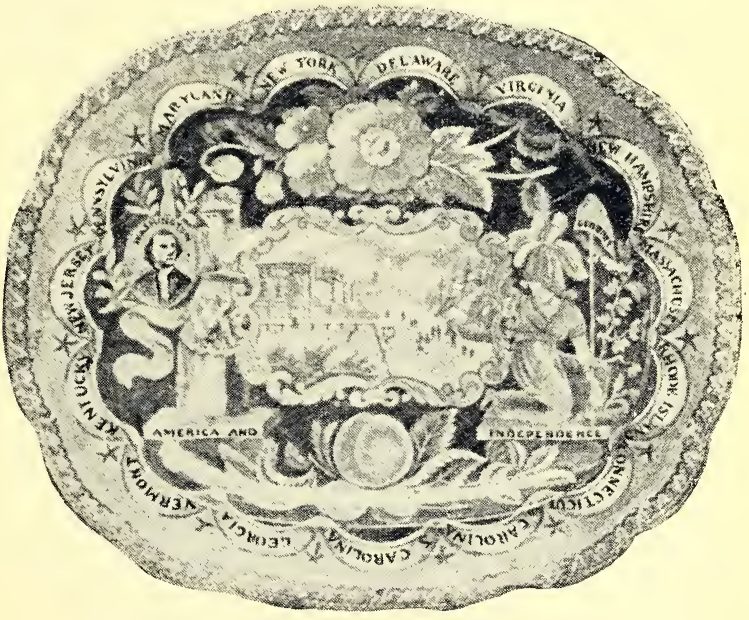
built up. The ware was marked "F. Wood" or "Enoch Wood," and later "Enoch Wood \& Sons." Mr. J. Bourne Pinder furnishes me with the following data respecting the succession: "One of the sons also dealt in borax and amassed a considerable fortune. He eventually withdrew from the firm, and as there was but little capital left, the Woods eventually went out of business. A manager of theirs then ran the potteries for a time, but it was soon closed and remained so until my father formed the firm of Pinder, Bourne \& Hope, and then re-opened them, our 
family living at Fountain Place House, a large, and in those days beautiful one, adjoining the pottery and where the Woods formerly lived. There were some good

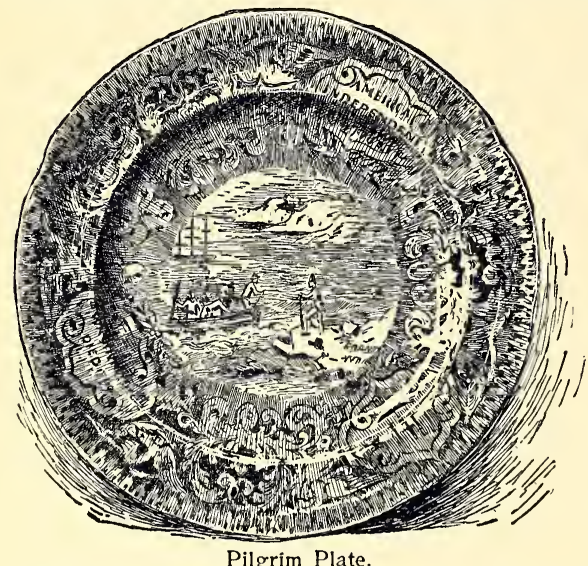
pieces of modeling in the house, one notably large piece in one of the halls representing the Crucifixion, executed by one of the Wood family. I remember we used to dig up lots of pieces of crockery of good shape and design that had evidently been made as experiments and not being perfect, had been buried in the garden. The firm of Pinder, Bourne \& Co. (plate 3, fig. 29) lasted ten years and was dissolved by mutual consentin 1861 . They had two factories, Fountain Place and Nile Street. My father and Mr. Bourne formed the partnership of Pinder, Bourne $\&$ Co. and went to Nile Street, confining themselves to trade with the Colonies and South America. Mr. Hope took in a Mr. Carter and styled themselves Hope and Carter and continued at the Fountain Place works, catering to the home trade. Pinder, Bourne \& Co. failed in 1877, my father having died in 1867, Mr. Bourne leaving the firm at his death. Doultons were old friends of ours, and my brother, Thomas Shadford Pinder, influenced them to go into business with him to make fine goods, which they did in 1877. The partnership only lasted until 1881, my brother retiring and the firm name was changed to Doulton \& Co. Mr. Bailey has been their manager ever since and to his credit, be it said, has brought this branch of the business to its present high standard.

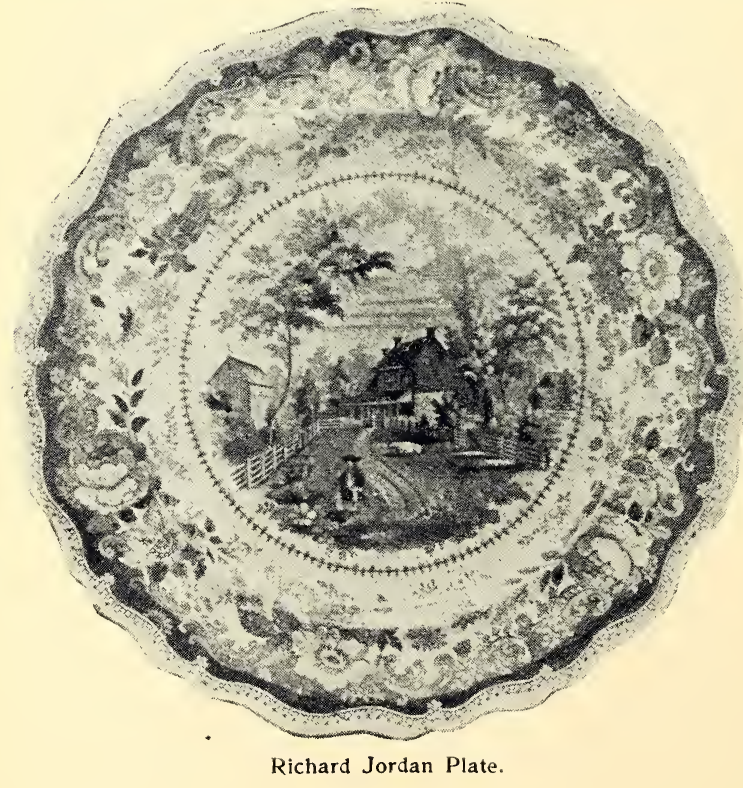

The Richard Jordan plate is often met with, but I do not know by whom it was made. He was a Quaker preacher, and was born in Virginia in 1756. At the beginning of the prese $\mathrm{n}$ century he lived at Hartford, Conn., and in 1809 settled at Newton, Gloucester County, N. J., where, in 1811 he built a house on a small farm adjoining the Meeting House, in which he resided until his death in 1826. The plate was probably, not issued until about ten years later.

The Swan Bank Works, Tunstall, belonged early in 
this century to Ralph Hall, who issued a good many American and other views. He was succeeded by Podmore Walker and Co., who carried on the works until 1862, when it passed into the hands of Beech and Hancock and from them to James Beech. (Plate 3, figs. 24 and 25.) Podmore Walker \& Co. also carried on the Unicorn Pottery, and were succeeded by Wedgwood \& Co.

The Dale Hall Works were founded in 1790 by Joseph Stubbs, who died in 1836, having a few years previously retired from business. He was succeeded by Mayer Bros., under whose management the works made rapid strides. Variuus changes in the firm name took place and perhaps the greatest variety of goods ever produced from one works emanated from here. The latest phase of the firm was Gildea and Walter. (Plate 3, fig. 11).

The Cobridge Works were erected in 1808, by Bucknall and Stevenson, who were succeeded by A. Stevenson. (Plate 4, fig. 11.) In 1816 or 1820 they passed

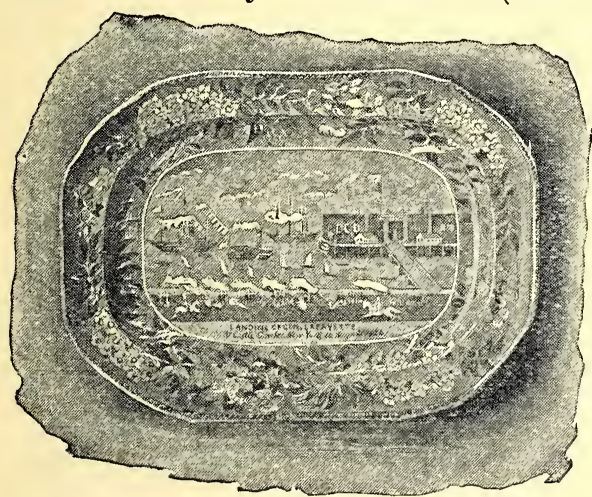

Landing of Lafayette. into the hands of James Clews, and he continued until 1829. For what reason he gave up the works I am unable to say, but in 1837 he came to this country and with the assistance of American capitalists, incorporated a company under the title of The Indiana Pottery Company, and built a factory at Troy, Indiana. But even with the assistance of English potters, who were brought over in large numbers, the venture did not prove successful and the factory was quickly closed and Mr. Clews returned to England. One son remained here, the present eminent financier, Henry Clews. Mr. James Carr, the veteran New York potter, worked for Clews when a boy, and afterwards employed many of the potters from the Troy factory. The Cobridge Works remained closed until 1836, when they were reopened by Robinson, Wood and Brownfield. Robinson died the same year and in 1850 Wood retired, leaving W. Brownfield to conduct the business. He died in 1873 , two years previously having admitted his son W. E. Brownfield as a partner, and the firm name became W. Brownfield \& Sons. (Plate 2, fig. 18.) This continued until a year or two ago when Mr. Brownfield determined in the interests of his workmen to convert it into a co-operative works and it is now known as the Brownfield Guild Pottery. (Plate 3, fig. 10).

The illustration given herewith is of a vase made by Messrs. Brownfield \& Sons for the Paris Exhibition and at that time was the largest china vase ever made. It is eleven feet in height and six feet four inches diameter. At the summit is a bisque figure of Ceres surrounded by attendants. The earth above which she stands is encircled by a zone resting on four brackets on which are seated four female figures also in bisque, typical of the four seasons. In the four panels of the zone are groups of children typical of the occupations of the seasons, whilst the pedestal from which spring the ornamental supports of the globe, is encircled ly sixty figures modeled in relief.

After bringing so large a piece to a successful issue, it was greatly disappoint- 
ing that it should receive a severe fracture on its way to the Exhibition; nor did

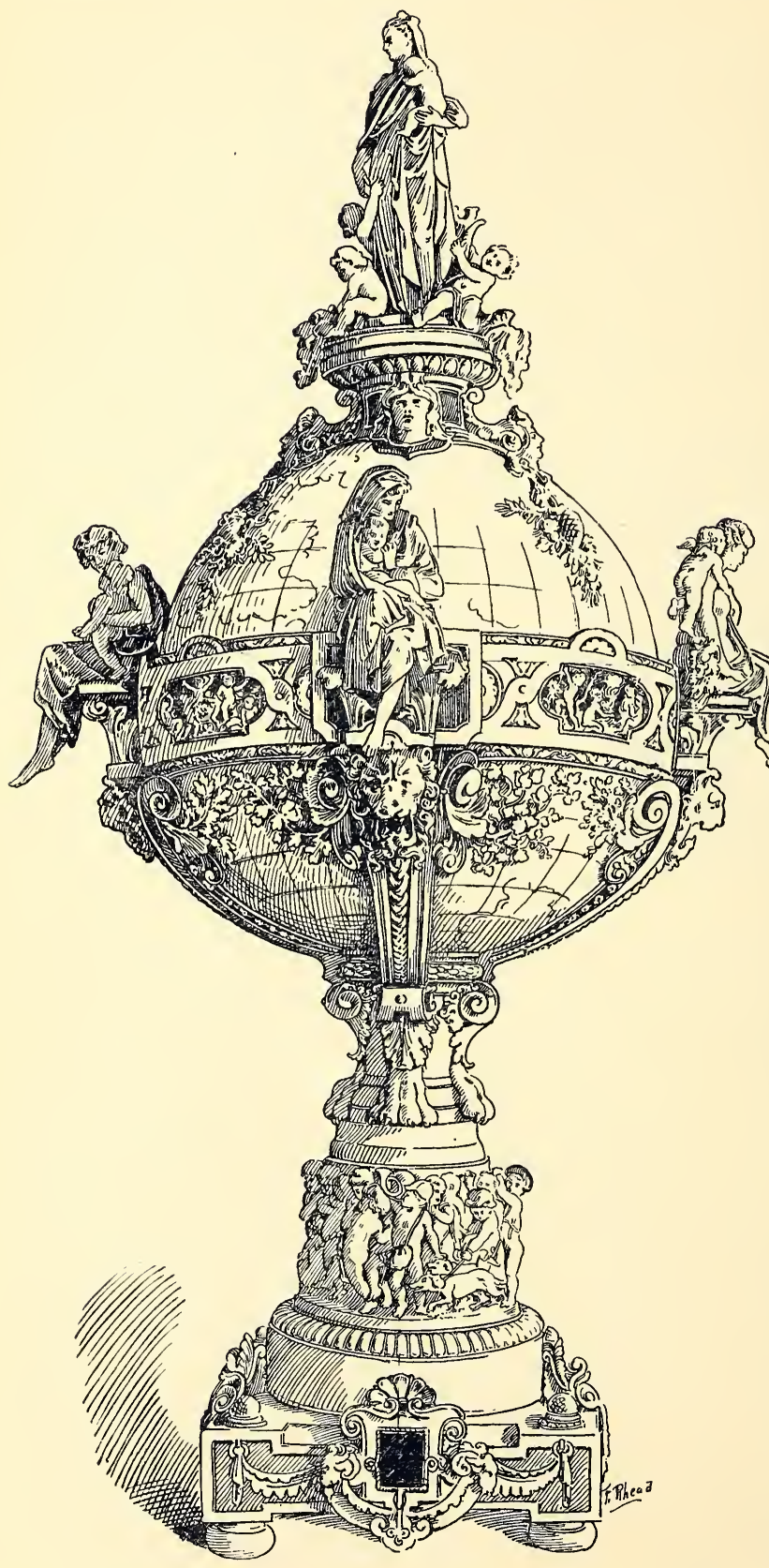
disaster end here, for it was entirely destroyed by a fire at the manufactory some year or so later.

Of J. \& W. Ridgway I have already spoken in the article on Cauldon. It was from the Cauldon factory that the "Beauties of America" series was issued and all others marked "J. \& IV. R.," "I. R.," or "J. R."

William Ridgway rented from $\mathrm{J}$ oseph Mayer in 1831 the Church Works at Hanley, and he was also associated with s e ver a l other factories, the Bell Works, now carried on by Clementson Bros., and another one close to it, now occupied by G. L. Ashworth \& Bros., and also the Charles Street works. He admitted his son, E. J. Ridgway, into partnership and the business was carried on by them until William Ridgway's death in 1864. E. J. Ridgway formed a partnership with I. J. Abington, $\mathrm{which}$ was dissolved in 1865 or 1866 . Mr. Sparks, their London representative, and E. J. Ridgway's Sons, John and E. A. Ridgway, entered the firm in 1872 ,

when Mr. E. J. Ridgway retired, the style being changed to Ridgway, Sparks \& Ridgway. The trademark which had hitherto been the Royal Arms, was now 
changed to a Staffordshire knot with the letters R. S. R. in the loops. Mr. Sparks died in 1878 and the style was changed to "Ridgways;" a new trademark, a bow and quiver of arrows being used. Mr. E. J. Ridgway died in May of the present year, aged 82.

Probably from the Church St. Works, William Ridgway issued a pattern called

"Catskill Moss," the centre having American views. This pattern seems to have escaped the notice of collectors. Has any reader any knowledge of it?

Mrs. Earle in "China Collecting in America," and Miss Prime in "The China Hunter's Club," have dealt at length with this interesting historical pottery, but the subject is by no means exhausted.

Of a later period, but possessing much interest, was a dinner set manufactured by E. F. Bodley \& Co., (Plate 3, fig 12), to the order of the Confederate government, for the warship "Alabama." It had a plain blue band with a device in the centre of two crossed cannons behind an anchor and the letters C. S. N., surrounded by a wreath of tobacco and cotton plant leaves. Underneath was the motto of the ship, "Aide toi et Dieu t'aidera."

\section{Martha Washington China.}

'Through the courtesy of Mr. A. True, of East 28th Street, New York, I am able to give an illustration from an authentic plate now in his possession, of the Martha Washington set, presented to her by officers of the French Navy. It is interesting from an historical point only, neither the body of the ware nor the decoration being especially fine.
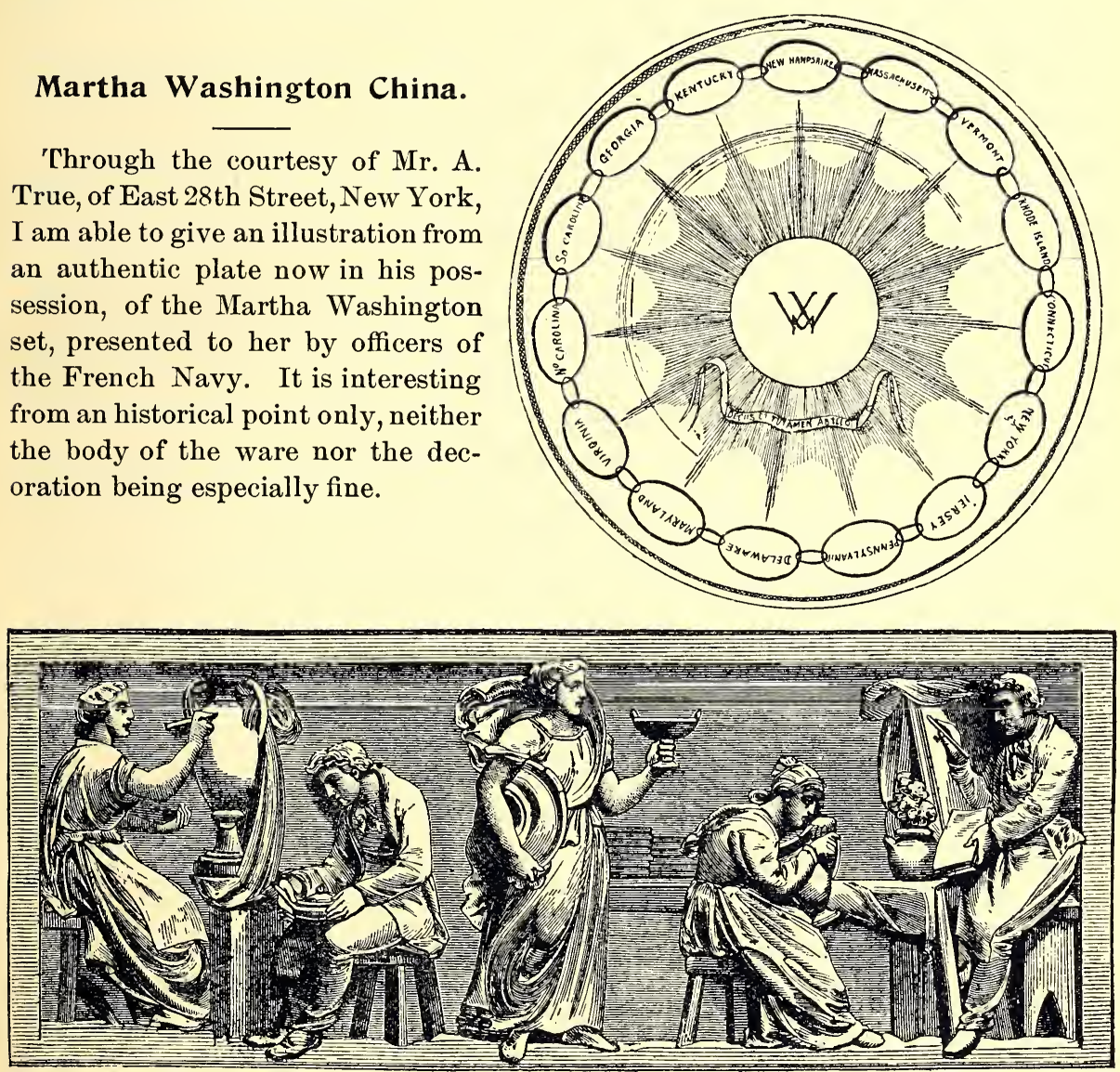

"Bas relief from Wedgwood Memorial Modeled by Walter J. Morris and produced in Terra Cotta by Blashfield of Stamford." 


\section{For the American Market.}

\section{$\mathrm{A}$}

FTER the exhibition at Philadelphia there immediately grew up a demand for decorated earthenware, in place of the plain and often clumsy White Granite with which we had before contented ourselves. This demand was at first supplied by the English manufacturers of decorated goods, but the shapes were not conformable to American ideas and the decorations did not appeal strongly to public taste. It was not long before the White Granite manufacturers saw their opportunity and commenced sending out some lighter designs, more in accordance with the demand here, and they have since held a tight rein on the market. The reputation attained for White Granite and semi porcelain by such houses as J. \& G. Meakin, Alfred Meakin, T. \& R. Boote, John Edwards, Furnival \& Sons, Wedgwood \& Co., Jas. Edwards, Maddocks, Alcocks and Burgess and Goddard stood them in good stead and a business colossal in its proportions, the waxing or waning of which means much to the Staffordshire potteries, has been built up. Johnson Bros. and W. H. Grindley \& Co., (Plate 2, Fig. 26), were late in the field, but by the elegance of their shapes and the attractiveness of their designs were soon abreast of the others. Such an extensive market was bound to attract others, and very many Staffordshire firms to-day who, half-a-dozen years ago, had never sent a single crate of goods here, have built up quite an extensive connection. The market also attracted a class of manufacturers whose products we could have dispensed with, makers of the cheapest possible grade of goods with nothing at all to recommend them except the price.

\section{"Your honors have seen such dishes." \\ -Shakespere, "Measure for Measure."}

Competition here had, of course, something to do with it-and by that I do not mean to refer to competition between American and English manufacturers-but rather the competition of importers, jobbers and storekeepers.

$T$. \& R. Boote. In the latter part of the last century the Waterloo Works were founded by Walter Daniel, who was succeeded by Timothy and John Locket. In 1809 the business was purchased by Joseph Machin and Jacob Baggaley. They made both china and earthenware. Machin died in 1831 and his son William succeeded him. The next phase of the firm was Richard Daniel and Thomas Edwards, from whom the business was purchased in 1850 by the present proprietors, Messrs. T. \& R. Boote. Parian and other specialties had been produced, but these were eventually abandoned and white ware only was made. Their familiar mark is known throughout the United States, and their success is the best evidence of the quality of their goods. Of late years Messrs. Boote have produced a large number of decorated patterns, some more successful than others, but all showing the exercise of artistic thoughtfulness in their applicability as decorative designs (plate 3, fig. 13).

The Old Hall Earthenware Co. (plate 3, fig. 19), was established by Job Meigh, in 1770. They make a fair quality of earthenware and have also quite a large trade in vases and ornamental goods.

George Jones \& Sons, Stoke-upon-Trent, was established by George Jones in 1861. He had formerly been with Mintons. Messrs. J. \& G. Meakin having more 
orders than they could execute, commissioned him to make White Granite for them and this he did at the Old Bridge Works, now occupied by Messrs. B. \& S. Hancock. Some years later he built a large factory and with the valuable assistance he received from his sons, quickly pushed himself to the front rank as a manufacturer cf china, majolica and earthenware. Their goods are deservedly popular and bear evidence of great care, both in design and workmanship. Mr. Jones died December 10, 1893, and the business is carried on by his sons (plate 2, fig. 14).

Johnson Bros. The Charles Street Works, Hanley, were founded by William Mellor, in 1758. He made Egyptian black ware, as did his successors, Toft and Wheeling. The works next passed into the hands of Toft and May, and a little later May alone conducted the business. He was succeded by William Ridgway, who changed the manufacture to that of white ware for the American market. The venture was unsuccessful and J.W. Pankhurst \& Co. succeeded him, from whom the works passed, some fifteen years ago, to their present proprietors, Messrs. Johnson Bros. Thanks to their enterprise they soon took front rank amongst those manufacturers who catered especially for this market, a position they seem likely to maintain. (Plate 2, figs. 48 and 49.)

J. \& G. Meakin. Mr. James Meakin commenced business in Longton, in 1845, but removed to Hanley in 1848. He retired in 1852 and was succeeded by his two sons, James and George. The business, principally with this country, grew to such large proportions, that in 1859 they built the Eagle Works, midway between Hanley and Fenton, one of the largest, if not the largest, White Granite works in the potteries.

Furnivals, Ltd., Cobridge. Their specialties are punch bowls and toilet ware, both of which they excel in, the latter from the originality of the designs and careful engraving and finishing, hold a leading position in the market. (Plate 3, fig. 17).

There are numerous other manufacturers in the potteries of equal importance to any of the above, and they are not particularized simply because I have no copy of their trade mark or other data of interest respecting them.

At Burton-on-Trent, Wm. Ault and Tooth \& Co. manufacture jardinieres and similar goods with richly colored glazes, very soft and harmonious.

The Burmantofts Pottery Co., Leeds, are unequalled for their colored glazes and produce a very large variety of artistic shapes, finely modeled and carefully made. It came as a revelation to the Staffordshire potters when first brought out.

The Della Robbia Pottery, at Birkenhead, has recently been established to "re-direct art energy towards industrial forms of daily need and use," and as such men as Holman Hunt are identifying themselves in its development, it will be interesting to watch its progress. 


\section{John Maddock \& Sons, L'td.}

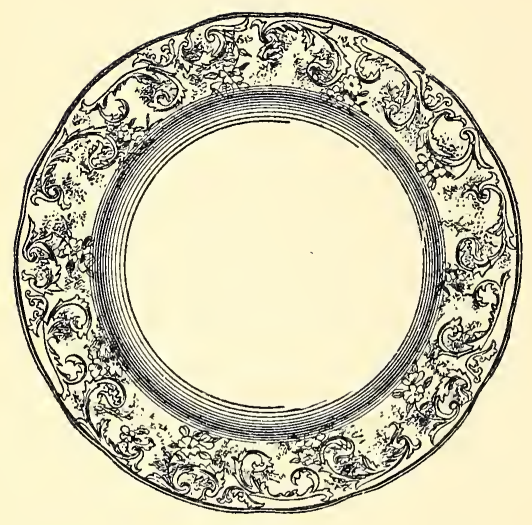

IN recognition of the high standard of excellence this firm has always maintained, and the just repute that has followed, as night follows day, they seem to me to deserve more than a passing notice. More particularly so since they occupy a somewhat unique position in the world of ceramics, having raised the manufacture of table earthenware a point higher than other Staffordshire houses engaged in the American trade. In manufacturing earthenware, the harder the body is made, the less is the liability of the ware to craze, always supposing that there is perfect affinity between the glaze and the body. To obtain a body of this degree of hardness, Messrs. Maddock have to employ a greater preponderance of its more expensive component parts, which enables it to stand such a degree of heat that a partial vitrification ensues, and the body and glaze being in perfect agreement, a ware is produced of such a homogeneous nature, that the risk of crazing is entirely removed. (Plate 2, figs. 24 and 25).

The original founder of the works at Burslem was John Maddock, who commenced business in 1830, and from the first his efforts were crowned with success. At an early date his attention was directed to this country as a market for his goods, and his son Jolın Maddock, Jr., spent a number of years here, opening up business connections, the results of which were reaped by his brothers, Thomas and Henry, who succeeded him. Another son, James Maddock, is the present head of the house, and is the only surviving son living in England. On his return there, after a visit to this country, in 1876, he considerably enlarged the works, which now give employment to over six hundred employees. Notwithstanding his multifarious duties at the factory, he has always taken a keen interest in municipal matters. He was elected to the highest honor his towns-people could confer upon him, that of Mayor of the ancient borough of Burslem, and the town has been many times the recipient of his liberality. Progressive and public-spirited, he has earned alike the respect of his neighbors and the affection of his work-people, and when the depression of the pottery industry in 1887-8 occurred, he kept his works in full operation. This affection found voice in an address presented to him by them with an accompanying substantial mark of their gratitude. These evidences of good feeling between employer and employed are always pleasurable matters to chronicle and perpetuate, and the following extract from the address needs no apology :

"We are proud of the high position the manufactures of the firm have attained and still maintain on the market, and we highly appreciate the honorable, fair and kindly treatment your employees have always received at your hands, your uniform and thoughtful consideration for them in times of sickness, the efforts you have put forth-sometimes to your own disadvantage-to provide work for them when trade has been depressed, and your endeavors as Chairman of the Board of Arbitration to secure and promote cordial relationship between capital and labor. As a testimonial of the honesty of these expressions of respect and esteem, we request your acceptance of the accompanying tray and two silver centre stands, and ask 
your permission to join with them our most cordial and heartfelt good wishes for the future well-being and happiness of yourself and your family."

Upon the death of John Maddock, Jr., his son, John Francis, was admitted as junior partner by his uncle, and much of the present management of the firm devolves upon him.

The reputation of their goods has been considerably enhanced by the character of the decorations employed, decorations very tasteful and effective, and often displaying a high order of art.

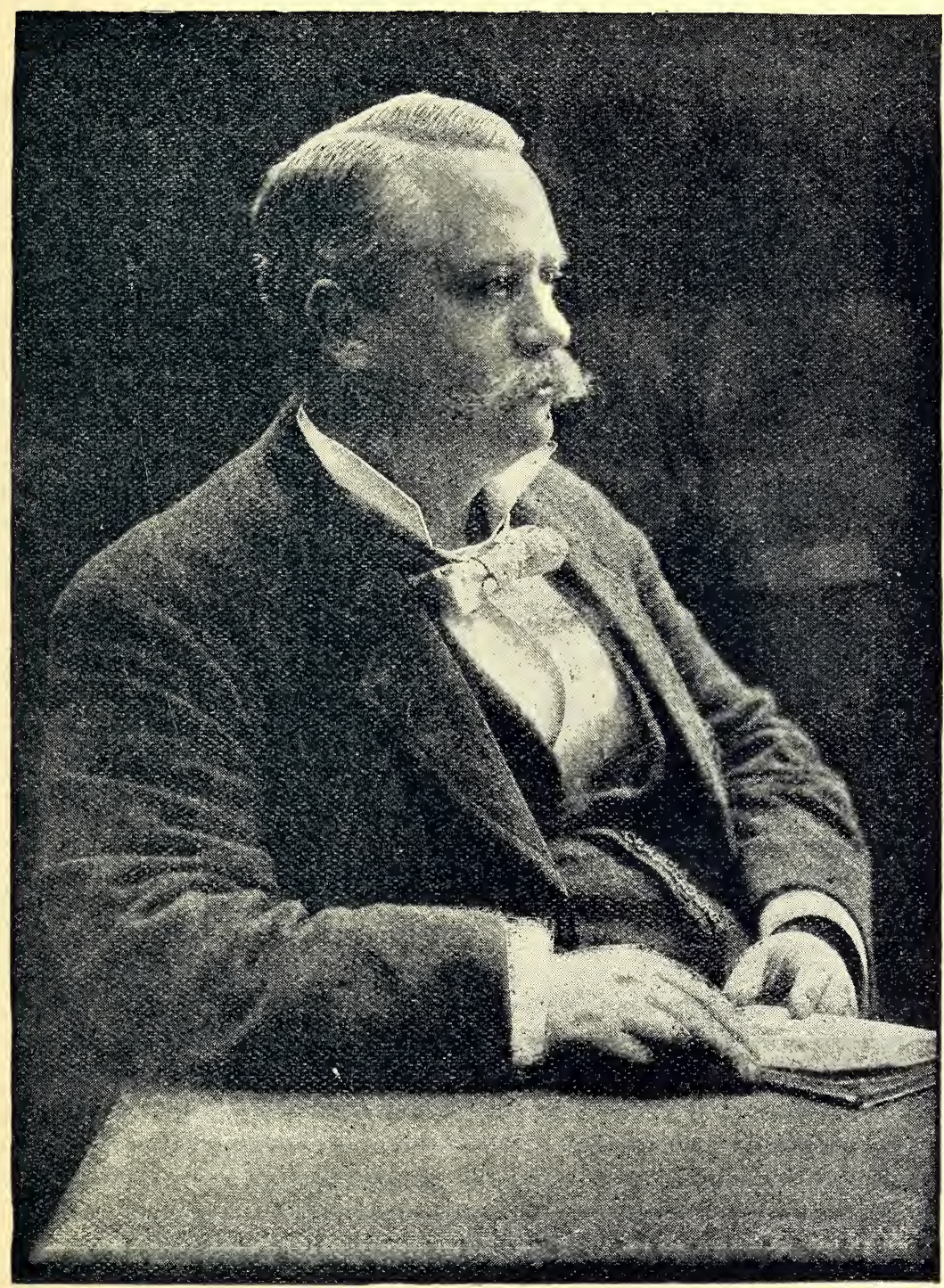




\section{Chelsea.}

$\mathrm{T}$

$\mathrm{HE}$ origin of the manufacture of pottery at Chelsea is doubtful, but was probably founded by Dutch workmen about the middle of the seventeenth century. It had attained some celebrity as early as 1745. George I. brought workmen, models and materials from Saxony, and enabled it to compete with Sévres and Dresden. In 1750, Sprimont was the director, and continued to be so until 1768, when the sharp competition of the Derby factory, which had acquired consid-

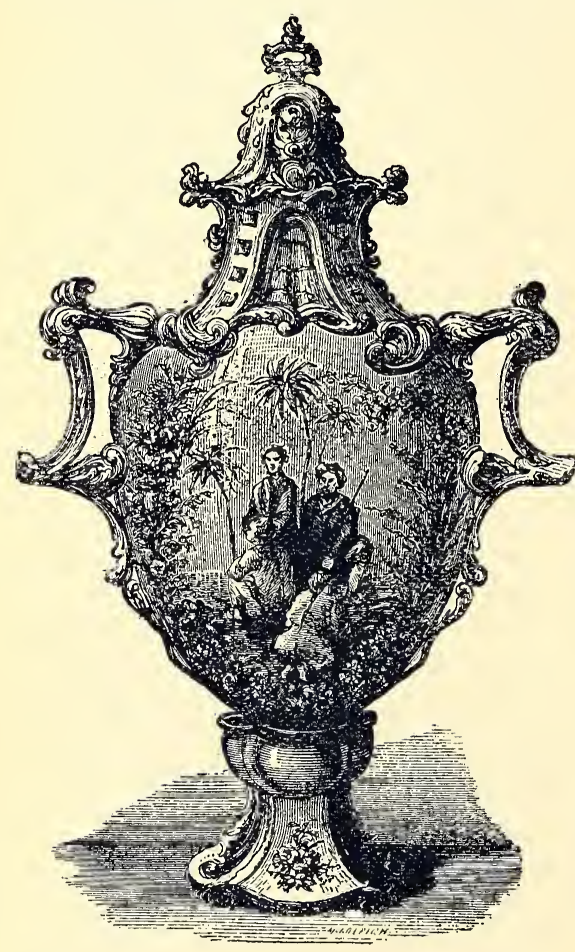
erable celebrity, together with failing health, caused him to relinquish it and the whole works, moulds, patterns-everything was sold out at public auction to William Duesbury, proprietor of the Derby factory. A great variety of china was manufactured at Chelsea, snuff boxes, smelling bottles, mounted in gold, statuettes and exquisite flowered pieces, handles for knives and similar articles, in addition to the more important dinner and tea ware. One peculiarity of Chelsea china, was, that it would not stand a second fire, and the body was not so compact as that of Derby. The colorsare all remarkably fine and vivid, the flower work delicately modeled, and only the best artists were employed. The product of the works, as was usual in those days, was disposed of at public auction. In 1763, Horace Walpole wrote of a magnificent set which cost $£ 1,200$. (about $\$ 6,000)$. As the purchasing power of money was much greater then than now, it must have been of very fine workmanship to command such a price. The distinguishing mark of Chelsea china was usually an anchor, though some is marked "Chelsea 1745," which is interesting as being the earliest dated example of English china. Other Chelsea marks will be found on plate 1. Jewett in his "Ceramic Art," gives in entenso a copy of a curious document addressed by the Chelsea works to the Custom House officials, and fixes the date about 1752. It recites that although painted Earthenware, other than that from India, is not enterable at the Custom House, other than for private use, the importations continue, shops abound with new stock, public sales are advertised at the very beginning of winter and in large quantities, and from the diminution in the price of Dresden china, it is believed that this is done to crush the manufactory established here, which was a project threatened last year. This earthen- 
ware pays $8 d$ by the pound when entered for private use, but a figure of very little weight may be worth $£ 5$, so that the real value of what is sold here will be found to be considerable. It may be said that a certain foreign minister's house has been, for a course of years, a warehouse for this commerce, and a large parcel advertised for public sale is come, or is to come from thence. A few examples of seizures would put a stop to this, as all Dresden china has a mark to distinguish it by ; but if this commerce is permitted to go on, the match between a crowned head and private people must be very unequal, and the foreign manufacturer will at any time by the sacrifice of a few thousand pounds have it in their power to ruin any undertaking of this kind here.

It is not recorded whether any answer was made to the ingenious petition, but it will afford food for reflection to the Political Economist that final disaster came, not from foreign, but home competition.

\section{Bow.}

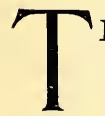

HERE does not appear to be any positive information as to when the china works of Stratford le Bow were founded, though we know that in 1750 they passed into the hands of Messrs. Weatherby and Crowther, and Mr. Binns has in his possession an inkstand with the inscription "Made at New Canton, 1750." This was the name the works were known by, and T. Craft, an artist employed there, writing in 1790 , respecting a punch bowl painted by himself in 1760, says: "The above (Bow) manufactory was carried on many years under the firm of Messrs. Crowther \& Weatherby, whose names were known almost over the world; they employed 300 persons ; about 90 painters (of whom I was one) and about 200 turners, throwers, \&c., were employed under one roof. The model of the building was taken from that at Canton in China; the whole was heated by two stoves on the outside of the building, and conveyed through flues or pipes and warmed the whole, sometimes to an intense heat, unbearable in winter. It now wears a miserable aspect, being a manùfactory for turpentine." It is, or was a few years ago, the match manufactory of Messrs. Bell and Black. The Bow works were in existence until 1775, when they were purchased by Duesbury of Derby.

The Bow China was a hard and rather coarse

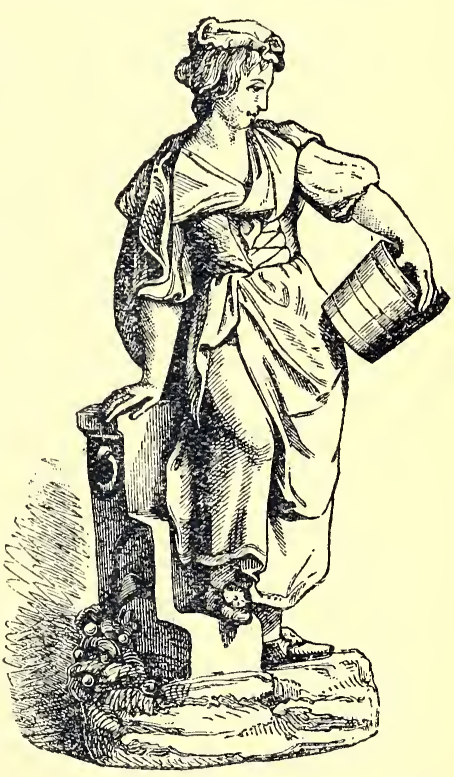

Bristol Figure. body, often marked with an embossed bee. It was the first china body in which bones formed a component part. The article on Spode gives further details on this interesting point. The Mayflower in relief was a favorite decoration, and they also produced some charming statuettes in bisque. John Bacon, the sculptor, and Moser, the keeper of the Royal Academy, a skilfull modeler, worked for the Bow factory. There is a good deal of confusion regarding Bow marks, but those given on plate 1are generally assumed to be Bow 


\section{Derby.}

$\mathrm{N}$ the year 1756 John Heath and William Duesbury entered into partnership with Andrew Planche, to manufacture china, on equal shares. Planche had formerly made small articles in china, cats, dogs, sheep, etc., which he fired in a pipe-maker's oven. Duesbury was an enameler from Longton, Staffordshire, and Mr. Heath found the capital. The undertaking seems to have becn a success from the first. In 1763 the higher sorts of porcelain, such as figures and vases, were made, and ten years later, such had been the growth of the business that premises were opened in London, and a list issued showing 123 additions made to their products that year. About the year 1781 the manufacture of bisque figures was commenced, and in this branch of the art they have never been excelled-possibly never equaled, and to the Derby factory is due the credit of their inception.

Planche seems to have dropped entirely out of sight, probably after imparting his knowledge and technical secrets, when he was no longer of use. William Duesbury died in 1786, and was succeeded by his son William. As narrated elsewhere, the Chelsea and Bow works had been morged into the Derby factory some eighteen years previously. In 1795 Michael Kean, a very clever miniature painter, was admitted into partwership, so as to relieve Duesbury of some of the responsibilities, but the experiment was not altogether a success, and Duesbury died shortly afterwards. Kean then married Mrs. Duesbury, but soon afterwards withdrew and the works were continued by the third William Duesbury. In 1815 he leased the premises to Robert Bloor. The Duesburys had always made it a point not to sell any but perfect pieces, so there was naturally a great accumulation of ware more or less defective. Bloor having to pay the purchase-money by installments, found the easiest method of doing so was to finish up these goods, take them to different towns, where they found ready sale, and also to have sales at the factory. One of these sales lasted twenty-five days. He amassed large sums of money by this means, but it produced a lasting evil. The temptation to produce large quantities of goods for auction was too great to be resisted, so less care was taken in the selection and manufacture of the goods, and the decline of the works commenced. (See Plate 1).

Bloor was succeeded in 1846 by Thomas Clark, who discontinued the works and sold most of the moulds, etc., to Staffordshire manufacturers. Some of the old employees commenced business on their own account, throwing into the common stock what tools, money or experience they had. The title of the firm was "Locker \& Co.," and in 1859, on Locker's death, changed to Steven son \& Co., subsequently becoming Hancock \& Co.

In 1877, Edward Phillips gave up his appointment as one of the managing directors of the Worcester Porcelain Co., and, in conjunction with Mr. William Litherland, a well-known china dealer of Liverpool, and Mr. John McInnes, formed a limited liability company with a capital of $£ 68,000$ for the manufacture of china at Derby, under the style of "The Crown Derby Porcelain Co." The first works were on the Osmaston road, but the old poor-house coming into the market it was 
purchased for $£ 10,000$ and converted into a manufactory. It was not, however, until 1880 that it was in full working order, and a revival of the old Derby shapes and patterns was successfully attempted. Mr. Phillips died in 1881, and Mr. Litherland a year later, and the management devolved on Henry Litherland and Edward McInnes. In 1891, aided by the late Duke of Devonshire, they obtained the privilege of adding "Royal" to the style of the firm. R. G. Morris, Ingram and Hogg, are the modelers; Jas. Rouse, who worked for Duesbury, continues his excellent flower pieces ; Holtzendorff is a painter of dreamy landscapes, whilst the figure-painters are Platts and Deakin. (Plate 3, fig. 6).

\section{Caughley=Coalport.}

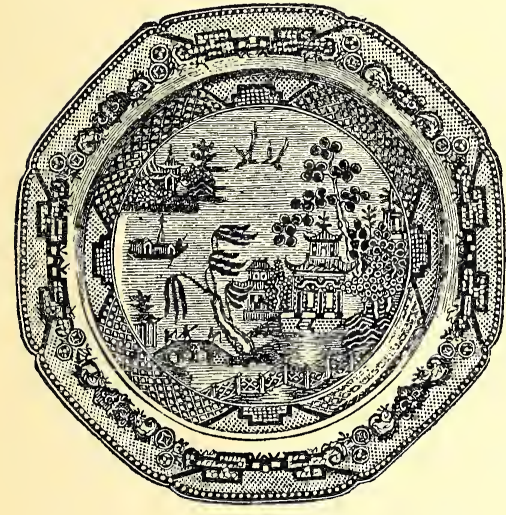

THE first Caughley factory was probably started by Gallimore, about the time of the inception of the Worcester works, though little is known about him. He was succeeded in 1772 by Thomas Turner, who appears to have supplied the plain china for decorating to both Robert Chamberlain and Grainger of Worcester. Jewett thinks that the printing for the Worcester Company was done here, on account of its isolated position, and it being possible to observe greater secrecy than at Worcester, the river Severn forming furthermore a convenient highway for its transportation.

Apprenticed to Turner was a youth named John Rose, the son of a neighboring farmer, who afterwards started in business on his own account at Jackfield, a little further up the river, but soon removed to Coalport, on the bank of the Severn opposite to Caughley. This had previously been a small pottery belonging to a Mr. Young. The venture was a success, so much so that in 1798 the opposition proved too strong for the Caughley works, and they were disposed of to Mr. Rose and his partner. Mr. Rose also acquired the Swansea Works (1820) and afterwards the Nantgarw, which had been founded by Derby workmen, " and which produced, perhaps, the finest examples of porcelain with a granulated fracture ever made." The moulds, patterns, etc., of these two works were, with the workmen, gradually removed to Coalport. Both in body and decoration excellent results were attained, its merits were speedily recognized and the standard of excellence has been maintained until the present day.

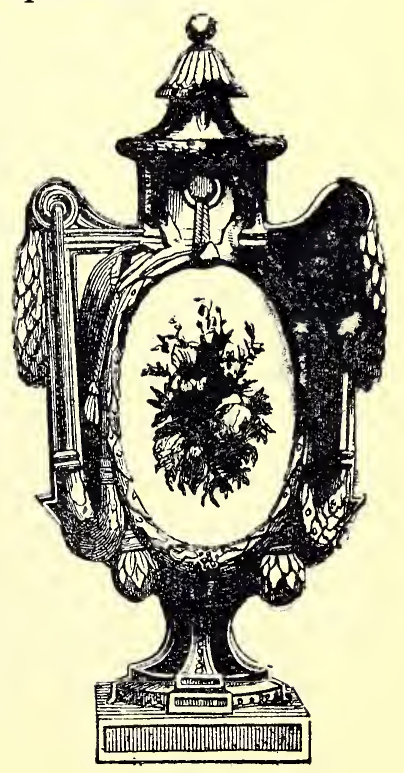


In 1820 the gold medal offered for the best porcelain glaze without lead, was awarded to Mr. Rose, having for competitors Copelands, Davenports and other well known Staffordshire houses.

John Rose died in 1841 and was succeded by his nephew, who was in turn

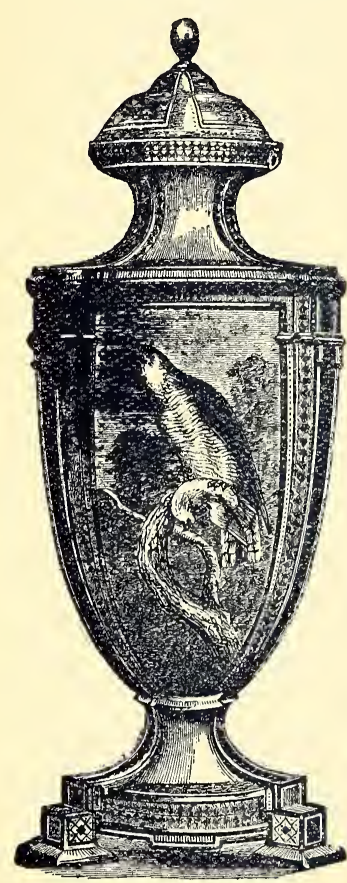

Vase, by Randall. succeeded by Mr. Pugh. Following his death a good deal of litigation ensued, and the business was conducted in a haphazard fashion. There was no actual supervision; the workmen simply made those articles for which they were best paid, and a vast accumulation of useless stock was the result. A gentleman named Bruff then bought the works. They were rescued from the annihilation that threatened them and to-day, under the directorship of Mr. J. J. Bott their productions increase in beauty and are more sought for than ever. Some of the old artists who helped to make Coalport what it is were Hartshorn, landscape painter; Cook, flower painter, and Randall, birds, etc. To this factory we owe the production of the world-famed Willow pattern, or, as it was called, "Broseley," the Blue Dragon or Canton pattern, and the almost as well-know Worm Sprig, Tournay Sprig and Berlin Chain, copies of Dresden patterns. Early specimens are marked as shown (plate 4, fig. 10), though marked pieces are the exception, whilst the present mark is a crown with "Coalport, A. D., 1750." (Plate 2, fig. 32.)

During the many changes in the proprietary, the style of the firm name has never changed. It has always been and is now "John Rose \& Co."

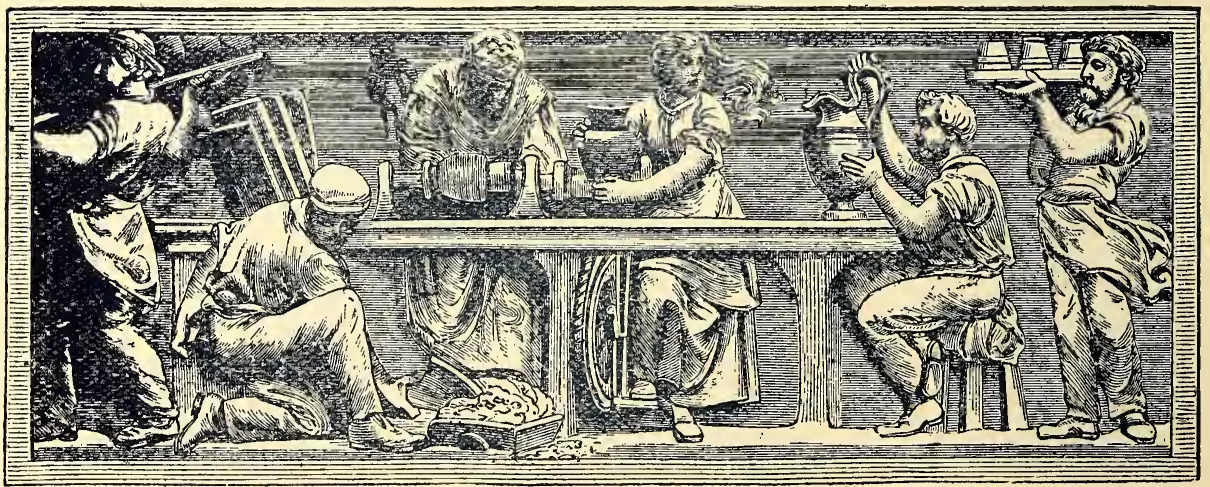

"Bas relief from Wedgwood Memorial." 
WORCESTER.

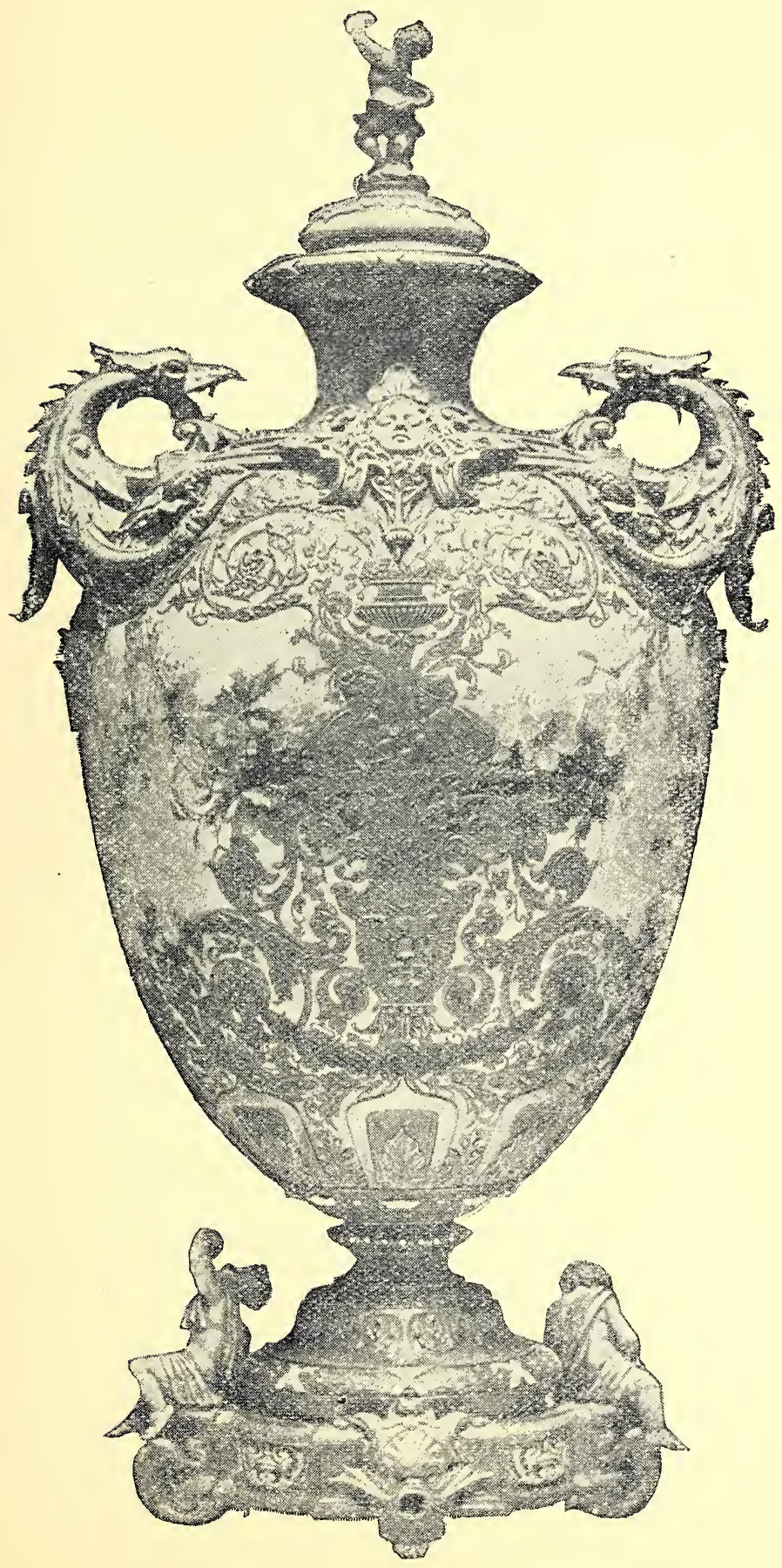




\section{Worcester.}

$\mathrm{D}$

R. WALL, a chemist of much practical ability and research, founded the Worcester Porcelain Co. in 1751, as a result of experiments he had long been engaged on. The original partnership deed relating to the formation of the Company is still in existence. The first productions were copies or adaptations of blue and white Nankin patterns, to which were soon added the more brilliant Japanese colorings. The much sought for square marks are copies of Japanese originals, the Worcester artists freely adopting them, as a little later they did the Dresden mark, when that style of decoration, in conjunction with that of Sèvres, was adopted. Early specimens have a somewhat cold and coarse look. In 1756, the invention of printing on biscuit china was introduced at Worcester. The credit of this discovery probably belongs to the Sadlers of Liverpool, who certainly printed tiles there in that year. It is also claimed for R. Handcock or Hancock of the Battersea Enamel Works, who came to Worcester in that year, and also for J. Holdship, one of the original partners of the Worcester factory, although the claims of the latter we find immediately challenged. A jug with a printed portrait of the King of Prussia inspired a long poem in the Gentleman's Magazine for December, 1757, and it was dedicated to Holdship. This poem, slightly altered, was reprinted in the Worcester Journal, for January, 1758, with the addition of the following significant couplet:

"Handcock, my friend, don't grieve, though Holdship has the praise.

'Tis yours to execute-'tis his to wear the bays."

Richard Holdship in 1751 became the lessee of the works, but becoming bankrupt in 1761, sold his shares for five shillings! and carried the secret of printing to the Derby Works. In 1769 Hancock purchased from the mortgagees of Richard Holdship the buildings he had erected, and became a partner in the works; but this partnership only lasted until 1774 .

About this time many of the Chelsea workmen immigrated to Worcester, and their influence was quickly felt in the style of the goods produced.

The worthy Dr. Wall died in 1776, and how much had been due to his skill as a potter, his acumen as a business man, was evidenced by the rapid deterioation of the quality of the products in the years succeeding his death. In 1783, John and Joseph Flight purchased the business and the prestige of the firm was quickly restored. They introduced simple decorations. In 1788, George III. visited the factory and suggested the use of the word "Royal" in the firm name, which was at once carried into effect and a crown added to the trademark. In $1793 \mathrm{Mr}$. Barr joined the firm and the various changes in style dated below followed.

Flight \& Barr, 1793 to 1807.

Barr, Flight \& Barr, 1807 to 1813.

Flight, Barr \& Barr, 1813 to 1840.

In 1786, Robert Chamberlain, the first apprentice the Worcester Company ever had, commenced business on his own account, at first buying china from Caughley to decorate, but soon manufacturing it for himself. He built up a large business and the two firms amalgamated in 1840, the business being carried on at the works 
and under the style of Chamberlain \& Co. (Plate 1, fig. 1.) In $1850 \mathrm{Mr}$. Kerr joined the firm and the year following $\mathrm{Mr}$. Chamberlain retired, his place being taken by Mr. R. W. Binns aud the firm name became Kerr \& Binns. Much progress was made in the next ten years, the works were considerably enlarged and at the end of that period Mr. Kerr retired and the business was continued by a company of shareholders, with Mr. R. W. Binns as art decorator, a position he has honorably filled and fills at the present day.

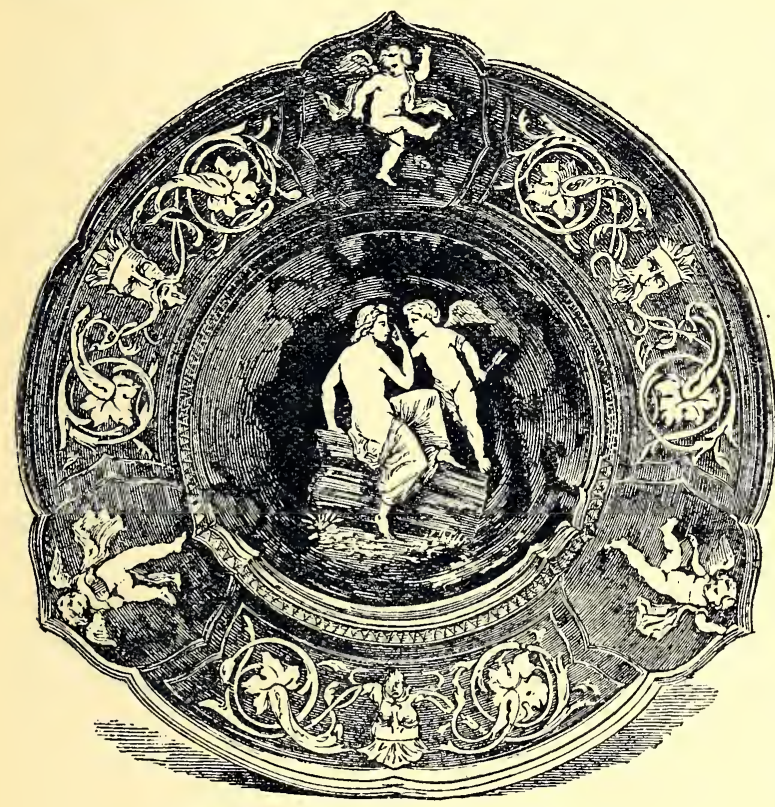

Tazza by Bott.

The enamels of Mr. Bott, a very clever artist, brought up by Mr. Binns specially for the work, were veritable triumphs of pottery.

It is, perhaps, by their ivory body, first made in 1854 , in which they produce an infinite variety of shapes and designs, that they are best known. Jeweled porcelain, a more ceramic production than that of Sèvres, parian statuettes, Worcester Japanese ware, and finely painted vases are some of the specialties of the firm. Both in form and design a very high ideal has always been aimed at, and this is especially noteworthy in tea and table services, produced mainly by mechanical processes. (Plate 3 , fig. 5).

\section{G. Grainger \& Co.}

\footnotetext{
A NOTHER Worcester firm of prominence was that of G. Grainger \& Co., estabA lished in 1800 by $\mathrm{Mr}$. Thomas Grainger, a nephew of $\mathrm{Mr}$. Chamberlain. Their principal productions are a highly vitrified semi-porcelain table ware, first produced in 1851, and a great variety of perforated glazed parian vases, very chaste in design and executed with great care. Since 1889 this factory has been taken over by the Royal Worcester Co., and is now operated by them. (Plate 2, fig. 31).
} 


\section{Lowestoft.}

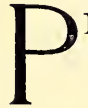

ERHAPS no china has given rise to more controversies than that of Lowestoft.

A pottery was established there in 1756 by Luson, but owing to the jealousy of some London manufacturers, who tampered with the workmen and induced them to spoil ware, it was not a success. However, in the year fol-

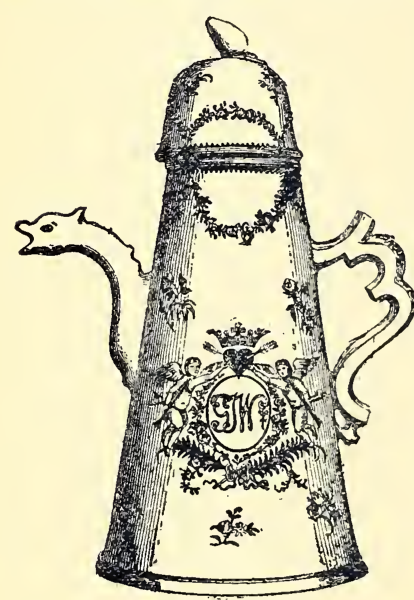
lowing, Walker, Brown \& Co., seem to have placed it on a fair footing and both earthenware and china were made. Many of the decorations were by Thomas Rose, who painted roses and small bouquets, both in groups and festoons. The works were abandoned in 1802. The claim was for a long time advanced that hard porcelain was made at Lowestoft, but it now seems reasonably certain that either Chinese ware was imported and decorated at Lowestoft, or that Lowestoft decorations were sent to China and copied there for the English market. The decorations are very simple in character, frequently with heraldic devices, but there was no distinguishing mark of any kind employed.

I have taken Jewitt as an authority, but the pros and cons are most entertainingly set forth in the last chapter of that most interesting of all books on pottery "The China Hunter's Club."'

\section{Doulton.}

N 1818, John Doulton established a stoneware works at Vauxhall. He was joined by John Watts and traded under the style of "Doulton \& Watts." Some few years after, the works were removed to Lambeth. From the first, a high order of merit was arrived at and achieved. There were no affected imitations of an antique type; character and originality were distinguishing features; all that was artistic found encouragement, and it was not long before a rough and crude manufacture was developed into one of artistic elegance. "What particularly arrests the eye is that each object has a style, which now takes us back to the flowery periods of Doric and Etruscan forms, now to the days of medieval hospitality. These works are not the results of the common course of earthenware productions, it has cost much thought and the exercise of much knowledge and ingenuity to appoint a confederacy of labor, so particularly qualified as shall work successfully to this special end."

The Doulton Lambeth ware is an earthenware body, highly vitrified, similar to the Grès from Germany. The ornament is princirally sgraffimento or incised out- 
line, made with a blunt tool on the wet clay, and afterwards colored with a brush and fired. The Lambeth works also have produced some of the rarest examples in Terra Cotta moulding ever seen, the work of George Tinworth being the most noticeable. Bricks, sewer pipes, \&c., are also made by the Doulton firm.

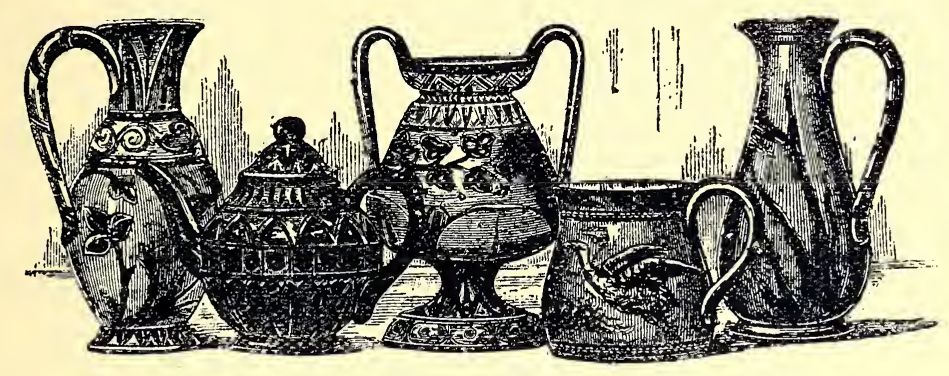

Early Lambeth Doulton.

Henry Doulton entered the firm at an early age, and under his skilful management fresh laurels were gained, the standard of the productions was higher and success seemed only an incentive to greater efforts. In 1877 the firm bought the works of Pinder, Bourne \& Co., at Burslem, at which one hundred and sixty people were employed. At the end of last year over one thousand were employed. Totally different to the goods they had been in the habit of making, they entered on this new venture with all their characteristic artistic enterprise. Formidable rivals were in control of the trade, but nothing daunted, they set to work, and in an incredibly short space of time there was on the market such a rich profusion of goods, both in china and earthenware, invested with so much artistic excellence and of so marked a character as to place the firm at once in the front ranks of Staffordshire manufacturers. Every piece of ware produced, from the cheapest dinner plate to the most expensive vase, bears this impress, a something indefinable yet plainly existent and for which I can find no better word than "Doultonesque."

Sir Henry Doulton-he was knighted in 1887-in a speech to his work people, said: "I remember when the power we employed in Lambeth, fifty or sixty years ago, was one blind horse. It is now 3,500 horse power and we have twentyfive steam boilers capable of generating steam equal to 7,000 horse power. In place of the music we have enjoyed to-night, I remember when the potters' recreation were drink and degrading fights between women; and when old Lambeth alleys, such as "Black-boy"-alley and "Naked-boy"-alley were sinks of infamy and disease. By the extension of our buildings many of these old plague spots have been removed. I began my work when 15 years old, at which age I went into the manufacturing department of my father's small business. There was no steam engine then; I had to push my wheel with my own foot. Often there was a kiln blazing just in front of where I worked. After two years I was able to make my first twenty gallon vessel on the wheel. I wanted to be able to criticise with intelligence. That was one of my motives when I deliberately chose to acquire a technical knowledge of pottery. I felt that if I were to be a judge of work, I at least should have a practical acquaintance with it. For a long time I confess I was prejudiced against the employment of women. I had witnessed the 
degrading effects of work on the women working in the potteries of Staffordshire, whey e women generally performed such heavy labor as turning the wheel, and wedging the clay. I had observed, too, especially on the Continent, that wherever women did what usually is men's work the men grew to be a lazy lot. Still, the matter was thoroughly thought out, and I at last saw my way to adopt a well organized scheme for the employment of young ladies. The success of the experiment was soon recognized, and nothing gave me greater pleasure than to see women working in those arts which tend to beautify and adorn life. In the year 1870 the first steps were taken at Lambeth to produce art pottery. I could say a good deal on this point, but let me now just observe that the only drawback to this department of our productions is that it cannot at present be extended." (Plate 3, fig. 14).

\section{Belleek.}

$\mathrm{B}$ ELLEEK is a fine glazed Parian body, washed with metallic lustres. It is made by what the French call the "coulage" process and which we designate as casting. A plaster mould is filled witl clay diluted by water to the consistency of cream and known as "slip." The plaster absorbing the water leaves a layer of clay adhering to the moulds, and when this attains the required thickness the remainder of the slip is emptied from the mould, and after drying for a short time the cast can easily be removed. Parian being a non-plastic body, cannot be either thrown or made in a dry mould. This ware first attained any degree of popularity at the manufactory of Messrs. McBirney \& Armstrong, of Belleek, County Fermanagh, Ireland, and took its name from that village. It had previously been successfully produced by Mr. W. H. Goss, of Stoke-upon-Trent. (Plate 2, fig. 10.) It was in 1863 that the first attempts to produce it were made at Belleek, but they were unsuccessful until McBirney \& Armstrong engaged Mr. Goss's foreman, William Bromley; a clever modeler named Gallimore and some ten other workmen from the same factory. Gallimore subsequently returned to Mr. Goss, as did most of the others, after teaching the process to their Irish friends, whilst Mrr. Bromley in 1883 came to Trenton to assist Mr. J. Hart Brewer in his development of Belleek. I have several times within recent dates seen it stated that Mr. W. H. Goss of Stoke-upon-Trent was the originator and inventor of the Belleck ware, and generally with the assumption that the iridescent coloring was in the glaze. Both these statements are incorrect. The real inventor of these pearly lustres was a Frenchman named Henri Brianchou, who protected by patent his discovery in France, England and Germany, and, I think, in one or two other countries. These lustres were used both in France and Germany long before their adoption by Mr. Goss, who, in common with Belleek and other factories, imported them from France during the continuance of the patent. These lustres are solutions of metal washed over the glaze and subsequently fired, and are no more a part of the glaze than is a line of gold or other enamel-kiln decoration. Mr. Goss started in business at Stoke in 1858; and in the London exhibition of 1862 does not appear to have exhibited any "Belleek" although he had a very choice exhibit of Parian figures, vases, \&c.; so that at the earliest, it seems reasonable to suppose he did not use these lustres 
before 1863, the year of the inception of the Irish manufactory. When Mr. Bromley went to Belleek he took with him the knowledge of a Parian body, whose composition Mr. Goss had adopted from an older body. Mr. Goss has a small manufactory at Stoke, where he produces some excellent specimens of Parian, and finds time to indulge his literary talents. I have used the word "small" advisably, as I have seen it described as "immense," which it is not and which Mr. Goss, in his own words takes "care that it shall not be ; for such a delicate maufacture would not admit of extension like an ordinary pottery. It would be dangerous to carry it beyond personal supervision." Beside improving the Belleek body, making it look richer and capable of standing boiling water, Mr. Goss has introduced a great improvement in the manner of fixing enamel jewels on china. He is a relative and also the biographer of Mr. Llewellyn Jewett. Many very elegant shapes and designs specially suited to the decorations emenated from the Belleek factory and had for a long time a certain popularity, but of late it has been made extensively at Trenton, equaling, if not excelling, the Belleek productions. (Plate 3, fig. $30 \& 31$.)

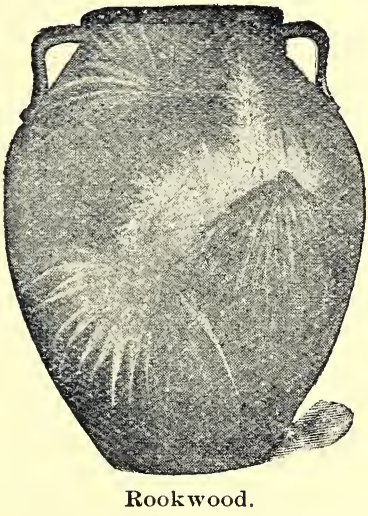




\title{
Pâte=sur=Pâte.
}

\author{
SPECIALLY CONTRIBUTED BY \\ M. SOLON, \\ AUTHOR OF "THE ART OF THE OLD ENGLISH POTTER."
}

\begin{abstract}
MONGST the various styles of decoration which the artist may borrow from the potter, the process of Pâte-sur-Pâte stands alone with regard to the peculiar effects that may be obtained from it. Wedgwood's jasper reliefs are the nearest approach, but the figures and the ornamentation with which
\end{abstract} jasper ware is adorned, are all pressed in moulds, and simply stuck on the surface. The result is, a work, which however skilful in treatment, does not go beyond the refined productions of a superior handicraft.

It is not so with the Pâte-sur-Pâte process. A plain piece, made of a porcelain body, colored with metallic oxides, and still in the clay state (that is to say, before it has been submittcd to any firing) is taken in hand by the artist. Freely he sketches upon it a subject of his own imagination. The white porcelain clay, diluted with water to the consistency of batter, or, as it is called, the "slip," serves to produce the reliefs. By means of a painting brush the slip is laid upon the piece by successive coats, care being taken to wait until the coat is perfectly dry before applying another. Failing that precaution the raised work might crack and peel off. Thus, by degrees, the reliefs attain their respective thicknesses. They are then worked into with sharp iron tools, which scrape and smooth the inequalities of the rough sketch, incise the details and delineate the outlines, whilst the brush loaded with thicker slip, brightens the whole work with sharply raised touches. When the piece is considered as completed and ready for the oven, it is, from beginning to end, the original production of the artist's hand.

But it is only through the action of the fire, which causes the incipient state of vitrification of the mass, that the translucency of certain parts will become apparent. When at work the artist has no means of ascertaining the degree of transparency that the firing will develop; he can only depend on his experience and judgment. All ends often in disappointment, for after the piece has passed through the oven, to retrieve any mistake, or to amend any accident has become an impossibility. One may rest satisfied if the fiuit of a long labor does not come from the firing split into fragments, disfigured by unseemly blisters, in short, an altogether worthless wreck.

Decoration in colored clays are applied in the same manner. The various colors are obtained by mixing with the porcelain body, given quantities of oxide of cobalt, chromium, iron, uranium, titanium, and other metalloids. These mixtures have to be artfully compounded in such a way that the contraction they undergo in the firing shall be equal in all cases.

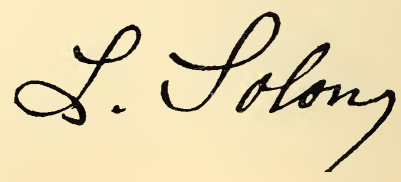




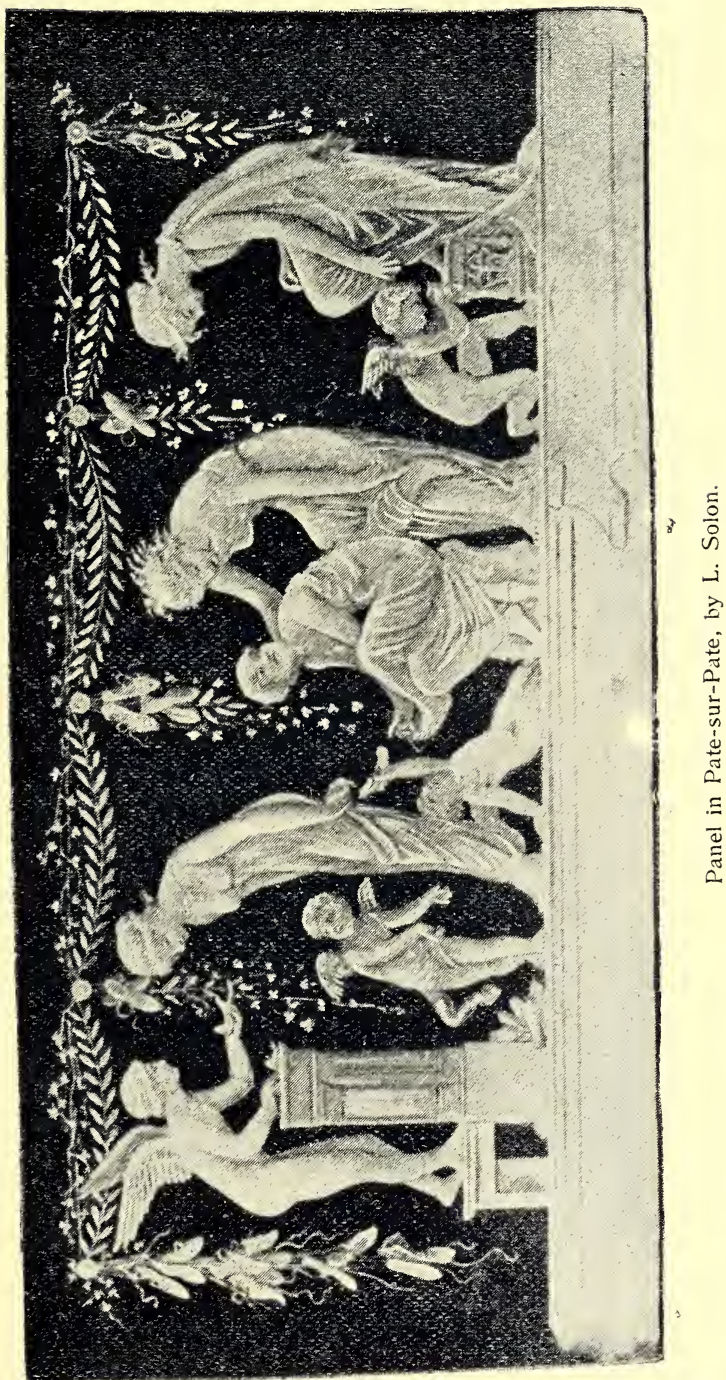




\section{The Staffordshire Potteries.}

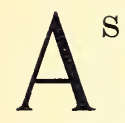

S some misapprehension seems to exist about the district known as "The Potteries," perhaps a few words on the subject will be acceptable. Situated in the northern part of the county of Staffordshire, about 150 miles northwest of London, is the district known as "The Potteries" which embraces Stoke-upon-Trent, Fenton, Longton, Hanley, Shelton, Cobridge, Etruria, Burslem, Longport, Dalehall and Tunstall. These towns cover a space about nine miles long and three wide, and have a combined population of about 200,000. Burslem-the mother of the Potteries-was originally "Burwardeslime," meaning the bower near the wood. Even in Wedgwood's time the only houses at Stoke were those of Ward (the Staffordshire historian) and Poulson, afterwards associated with Minton. Newcastle was the nearest market place to Burslem, but the roads were so bad as to be almost impassable, in addition to being infested with highwaymen. A part of this road or lane is still in existence, much as it was a hundred years ago. Longport was formerly Longbridge, owing to the floods of water which gathered in the valley. The long bridge consisted of about a hundred yards of plank, made by the assistance of stones, to span the water-course, which at times was deep and rapid.

Stoke-upon-Trent has the best railroad facilities and perhaps for this reason is regarded as the metropolis of the potteries, a distinction also claimed by Hanley, on account of its progressiveness.

Tunstall, from the Anglo-Saxon tun, a town and stall, an elevated seat, was held in the time of Henry III, as fief under the manor of Newcastle, by Henry de Audley. The ironstone with which Tunstall abounds was worked as early as 1316 . It was not however until 1816 that the town became of any importance.

The Old Hall Manufactory at Hanley, locally "T'wod Awe Bonk" (for in the Potteries every factory is a 'bank'), carries us back to the Norman Conquest when William de Hanley was lord of the manor and had his residence there. Etruria was created by Wedgwood; Shelton is mostly the over growth of Stoke and Hanley, whilst Longton, meaning long town, was formerly Lane End, a name requiring no explanation. Newcastle, about two miles from Stoke, disdains connection with the Potteries, content with the prestige of being one of the oldest boroughs in England. Here was born Major-General Harriscn, one of the chiefs of the army of the Commonwealth; Fenton the poet, and John Goodwin, a celebrated divine who by his pen probably did as much for Cromwell's cause as Harrison did with his sword.

Notwithstanding the smoke and grime from the ovens and furnaces, there is a marked absence of epidemics, the potters' worst foes being asthma and lead poisoning, but thanks to strict government supervision, the better ventilation and greater cleanliness of the workshops, these diseases are markedly on the wane. The potter is generally a Wesleyan, in atonement, I suppose, for the shower of bricks and stones hurled at Wesley on his first visit to Burslem. He takes a strong interest in politics, mostly in the winter, for at other times his beloved patch of garlen occupies all his leisure. Beer is his favorite beverage, but of late years, thanks to the influence of such institutions as the Wedgwood Institute and the Schools of Design, of which each town boasts of one, the present generation is more sober and better educated, whilst losing nothing of the kindheartedness and hospitality for 
which they have always been celebrated. Sixty years ago at Burslem there was but one old constable in the town. He was named Cooper and was often greatly distressed on Saturday night, his complaint being "What can I do? They're faighting from Enoch Woods to Billy Barlow's. If there's one man stripped to his buff there's a hundred; and if I charge the peace it's no use, for they won't take any notice of me." Every year at the annual holiday, "the Wakes," there was bull baiting in the public square and on the Green. The bull baiting has long been discontinued, but the wakes are still an honored institution, though yearly they are less patronized, the potter finding more enjoyment in a trip to the seaside than amongst the crowd of itinerant showmen, who for the nonce monopolize the public square. With all its blackness, no district has a brighter border land than that which surrounds the Potteries. Remnants of vast forests that one time covered the district, remain at Trentham, the seat of the Duke of Sutherland, and the park and woods are free to all. Alton Towers, Lord Shrewsbury's estate, is but a few miles distant and that in turn is close to Dovedale immortalized by Isaac Walton, whilst nearer home the Moorlands at Leek, or the historic ground beyond Newcastle, open up wide fields of enjoyment and the potter at his leisure explores them all. An ardent sportsman, he industriously whips the streams of the Dove or Blyth, and recounts his adventures at the monthly meeting of the club to which he belongs, between the puffs from his long Brosely or more convenient briar, for to him the cigar is an almost unknown quantity.

The Potteries are often confounded with the Black Country, a district engaged in the iron trade and in the southern part of Staffordshire.

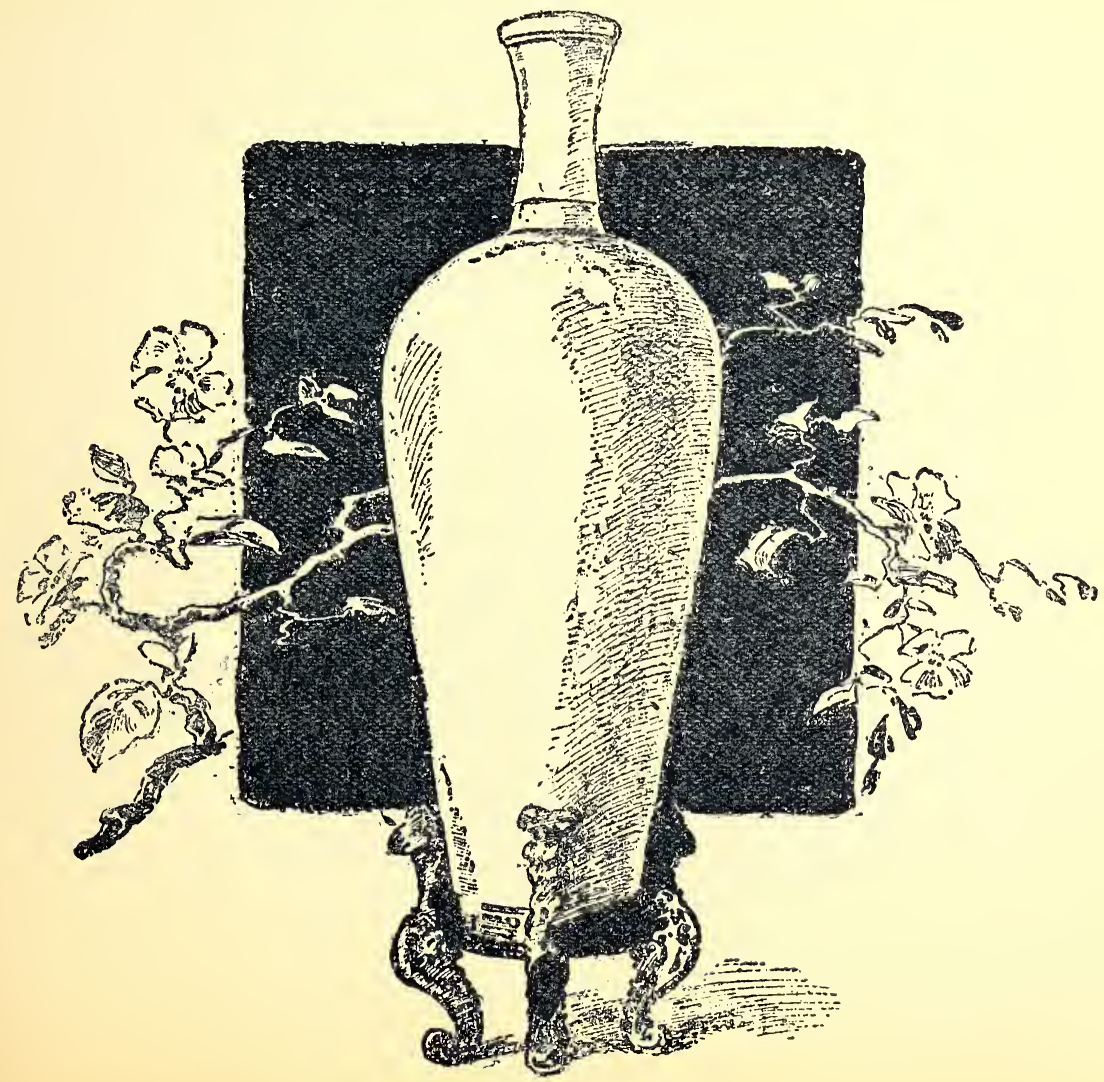




\section{France.}

Bernard Palissy.

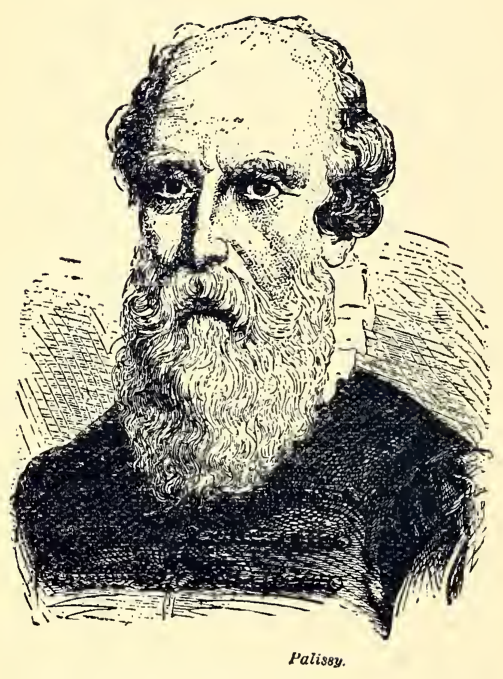

Bernard Palissy in the galaxy of eminent potters stands out in bold relief, and the romance of his life, as told by himself, is one of the most thrilling autobiographies ever written. Professor Henry Morley in hiș "Palissy, the Potter," has produced a work of rare interest and I would strongly urge those who have not read it to do so.

Bernard Palissy was born at La Chapelle Biron, province of Périgord, France, in the year 1510. His father was a glass painter and he taught his son the same art. At a very early age, owing to the poverty of his parents, he was thrown upon his own resources for even the most rudimentary education. His indomitable energy was a marked trait in his character, even as a boy; and he read and studied every book within his reach and acquired more than a rudi-

mentary knowledge of chemistry, geology and botany. The training for his art as a glass painter made him a skilled draughtsman and taught him the manipulation of colors. Upon completing his apprenticeship he married and settled at Saintes, varying his occupation by portrait painting and land surveying, whilst to his studies he added history and classical mythology. One day, not many years after his marriage, he saw a fine piece of enameled pottery. Charmed with its surface, "soft as the touch of a baby's hand," Knowing absolutely nothing of the art of Pottery, totally unacquainted with the composition of the enamel, he bent himself to the task of mastering it with the determination characteristic of him. At the neighboring village of La Chapelle des Pots, he learned the rudiments of the potter's art; his own profession had taught him something of painting and firing of enamel colors, and on this slender basis he commenced his experiments.

Year after year he struggled on, often groping blindly, sometimes with a gleam of hope, but never wholly disheartened. His friends and neighbors looked upon him as a madman. Often his wife and children went supperless to bed, the last penny spent to purchase the wherewithal to pursue his investigations. In vain his wife pleaded ; the kiln with its capacious and unrelenting maw swallowed up everything and the direst poverty stared them in the face. For nearly sixteen years he struggled on, enduring the reproaches of his wife, the death of his children, the pathetic look of hunger in the faces of those spared to him, and the revilings of his 
neighbors. He felt that he was nearing the solution of the problem, but with exhausted credit he could no longer procure fuel to fire his kiln. Success he felt was within his grasp, and undaunted by failure, he sacrificed his furniture for fuel. One by one the few domestic articles disappeared in the kiln, his wife and children, hungry and ragged, in vain imploring him to desist. If this failed, it was of necessity his last experiment. The very last stick of furniture had been thrust in the kiln, the house had been stripped of every vestige of woodwork and who shall attempt to portray with what emotions Palissy awaited the result. At last the time arrived when he should know whether he had been successful or-but he dared not face, even to himself, the alternative. With trembling hands he drew the few pieces from the kiln-for a moment he dared not trust his senses-he looked again-the enamel had fused and the success he had toiled for so long had come.

For some years Palissy enjoyed untroubled reward for his years of toil and unflinching tenacity of purpose, patronized by Catharine de Medici;-courted by those who had previously reviled him as a madman. He becamed enthralled with the doctrines of the Reformation, devoted himself heart and soul to the cause, and in 1558 was arrested and imprisoned at Bordeaux, his kilns and materials being destroyed. Through the intervention of the king, he was liberated in 1563 and set up a pottery in Paris, where until 1588, he lived and prospered, but a fresh wave of religious intolerance swept over the country and he was in that year sent to the Bastile. Henry III. offered him his freedom if he would recant, but the stern old potter indignantly refused, and he was sentenced to execution, but died in 1589, before it was carried out, nearly eighty years of age.

Palissy occupied an important position as a writer, perhaps more so than a potter. He wrote on such varied subjects as religion, agriculture, and natural philosophy, but his book, "L'Art de terre," in which he gives the story of his life and works is perhaps his best known work. We know from this book that Palissy was aware that the enamel was in common use in Italy at the time he was making his experi-

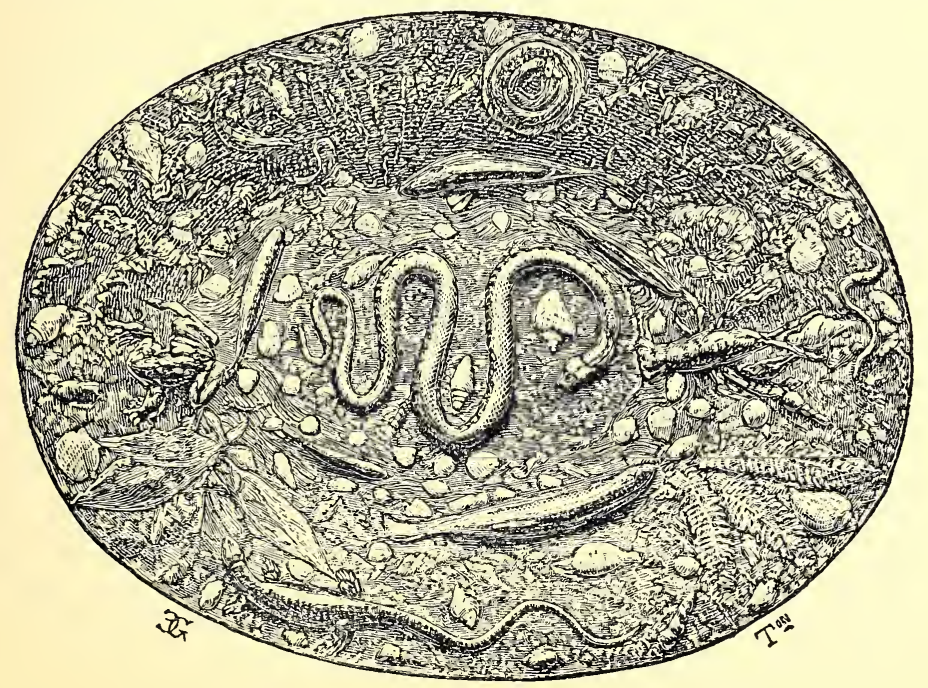


ments (as also it was at Rouen), and that its secret could have been learned in the workshop there, "but in no workshop could he have learned the secret of his enamels, so pure, so brilliant, so rich and deep in tone, that they have never been equalled since, and admittedly rank amongst the most wonderful production of human industry." His first productions, to use his own words, were "those vessels of intermixed colors after the manner of Jasper." They are warmly and brilliantly colored and covered with a j,ure and deeply toned glaze. Later he made his celebrated Rustic dishes, decorated with realistic figures of natural objects, snakes, fish, insects, shells and plants. There is a wonderful wealth of detail in these, ensured by moulds taken from casts made from the objects themselves. The body was a hard, well fired earthenware. His later works somewhat deteriorated and lacked the care and finish bestowed on earlier specimens. Unfortunately Palissy did not confide to others the secret of making his enamel and it died with him.

There are obvious inferences to be drawn from the life of Palissy, and we must not allow his success to blind us to his neglect of his wife and family. A row of tiny graves, a neglected wife, a desolate home, all rise before our vision, and we are tempted to ask whether success was not purchased at too great a cost.

Imitations of Palissy ware have been made by Barbizet, of Paris; Avisseau, of Tours, and Calder, in Portugal.

\section{Faïence d'Oiron.}

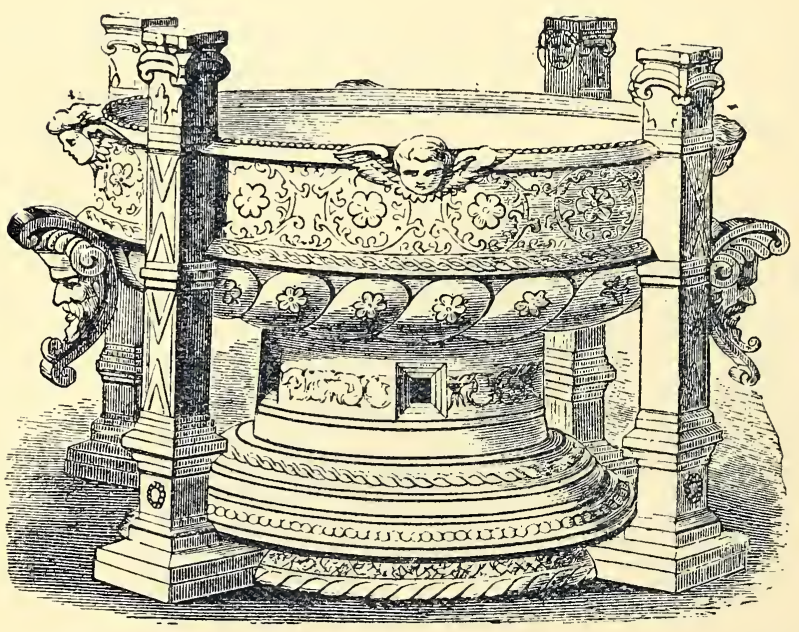

H IS celebrated
ware is often
incorrectly called "Henri deux" ware, it being thought to be the production of a pottery established under that monarch's patronage, owing to the frequency of his emblem forming a component part of the decoration. Comparatively recent research, however, has established its real origin by incontrovertible
1524 and 1537 , at the documentary evidence. It was made between the years 1524 and 1537, at the
Chateau d'Oiron, in the province of Thouars in France, by François Cherpentier and Jehan Bernart, under the direction of a wealthy lady named Hélène de Hangest. It appears to have been made entirely for presentation purposes, and only about fifty pieces are said to be in existence. There are eleven pieces in the Louvre, five in the South Kensington Museum, and the remainder in the hands of private collec- 
tors, mostly the Rothschilds. From their rarity the specimens are extremely valuable, ranging in value from four to forty thousand dollars each. The forms are in most cases very elaborate, and consist of ewers, salt cellars, tazzas, plates, \&c. The ware is a fine white clay to which a delicate cream tint is given, by a very slight tinge of yellow in the glaze. The patterns, which were very intricate and seem to have been suggested by the highly ornate book covers of the period, were first incised or impressed in the clay, and then these sunk portions were filled up with different colored clays in dark brown, soft yellow and buff. As all these clays had to shrink during the firing in exactly the same proportion, the difficulties attending the manufacture can be readily estimated. It is this triumph of potting that gives them their especial value. After the death of Hélène de Hangest, in 1537, the manufacture was carried on under the direction of her son, but the artistic spirit of his mother was wanting, and after the death of Cherpentier and Bernart, the manufacture fell into inexperienced hands, was neglected, decayed and soon disappeared altogether. The mark plate 3 , fig. 23 , is often incorporated in the designs. Mintons produced some excellent copies of this ware, executed by Charles Toft, as did also Deck of Paris, but they have, of course, only a relative value.

\section{French Faience and Earthenware.}

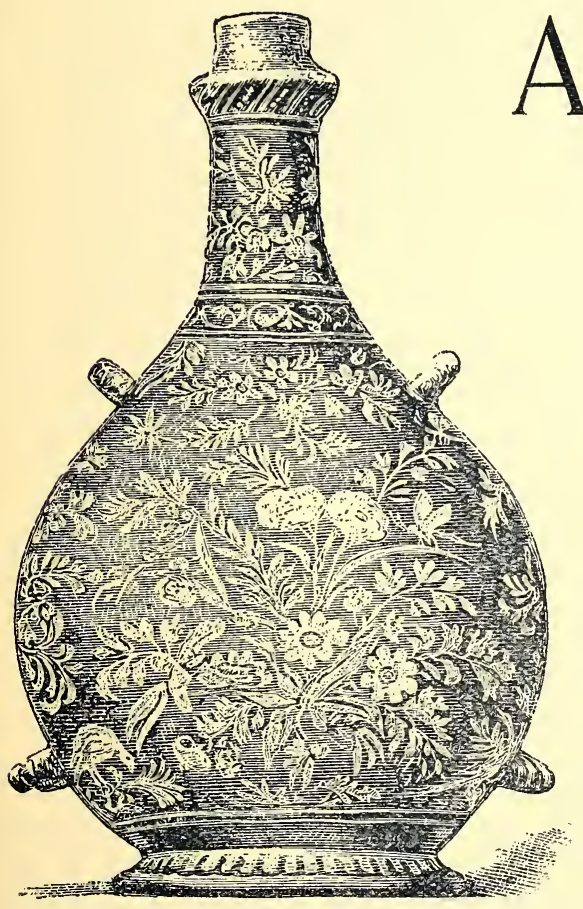

Nevers Vase.
LTHOUGH the production of faïence was vigorously carried on in Italy during the 16th century, except for a few isolated cases the art was not established in France (although that period could boast of two distinct kinds of pottery, which secured immortal fame: the Oiron and the Palissy wares) until the following century. The industry then assumed great importance and for upwards of a century France had no rival in the art. The French productions were distinctly characteristic, establishing certain classifications by which they are still known. Rouen, Nevers, Moustiers and Strasburg, each suggests a certain style. During the first period the decoration was applied on the unfired enamel; and towards the middle of the 18th century this gave place to decorations on the enamel which had first been fired. Nevers ware is important on account of its extent. From an artistic point it had little influence, because it lacked 
originality. Its designs were mostly copies, or adapted from Italian or Chinese originals. During its last period it was greatly debased, consisting mostly of figure subjects, poorly drawn and executed, and often overstepping the bounds of decency. (Plate 1, fig. 14). To all these objections there is one notable exception. Certain pieces, probably manufactured by Custode, have an exquisite Persian blue ground, decorated with white enamel and sometimes low tones of yellow. Nothing can equal this blue glaze for purity and depth, and though many tried to equal it they signally failed in the attempt. It greatly resembles and can easily be mistaken for Persian enamel.

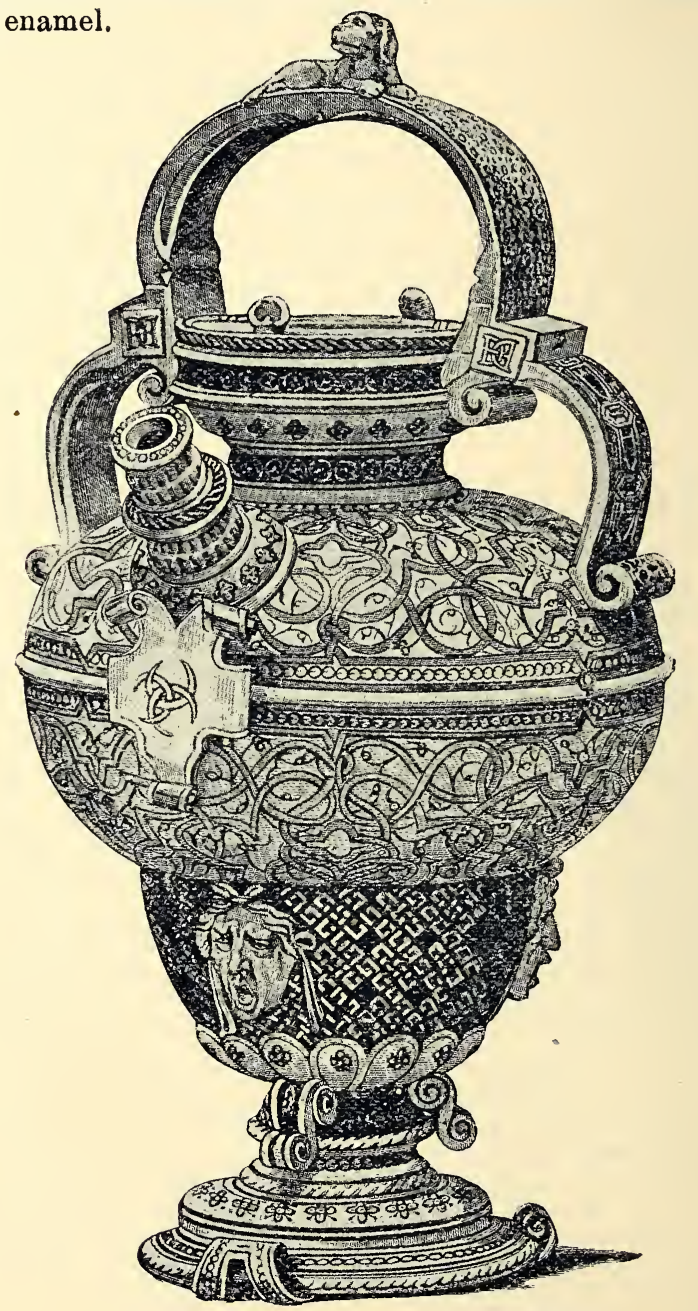

Fäience d'Oiron. Biberon. (See page 54.)

Rouen is celebrated for the beautiful and elaborate style of decoration originated there consisting of alternate repeated ornaments called $\grave{a}$ lambrequins, the designs being adapted from textile fabrics, lace, \&c. These are mostly in blue, sometimes heigbtened with indian red, a color identified with the Norman town and which others vainly tried to imitate. Another decoration was termed rayonnant in which the design rising from the border of the piece converges to the centre. 
FRENCH FAIENCE AND EARTHENIVARE.
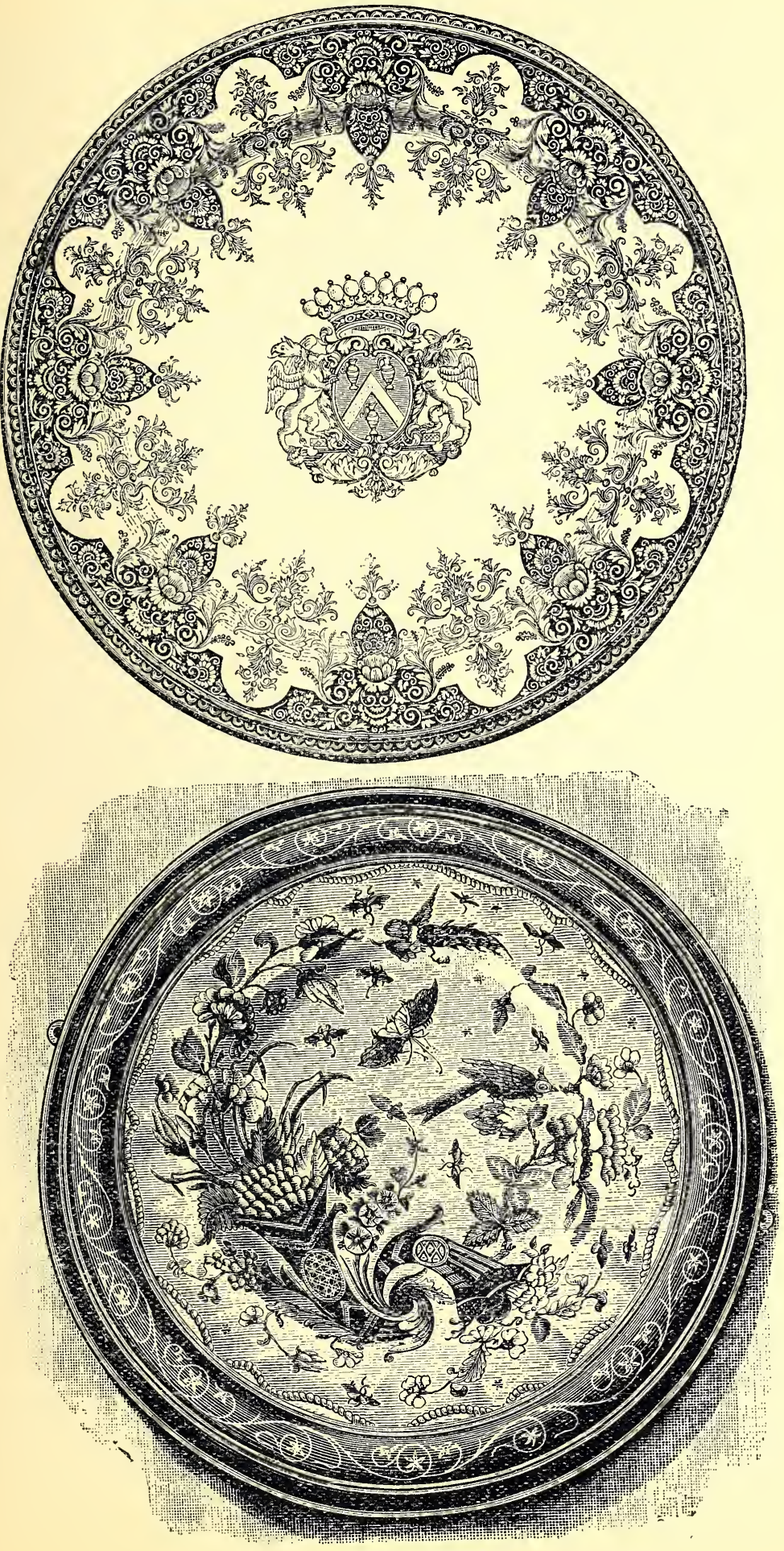

Rouen Dishes. 
Towards the middle of the 18th century, polychrome decoration was freely used and this induced a change of style, borders of flowers giving place to more conventional designs. The "Cornucopia" pattern was the last success of Rouen, for the increased use of porcelain, the treaty admitting English earthenware and

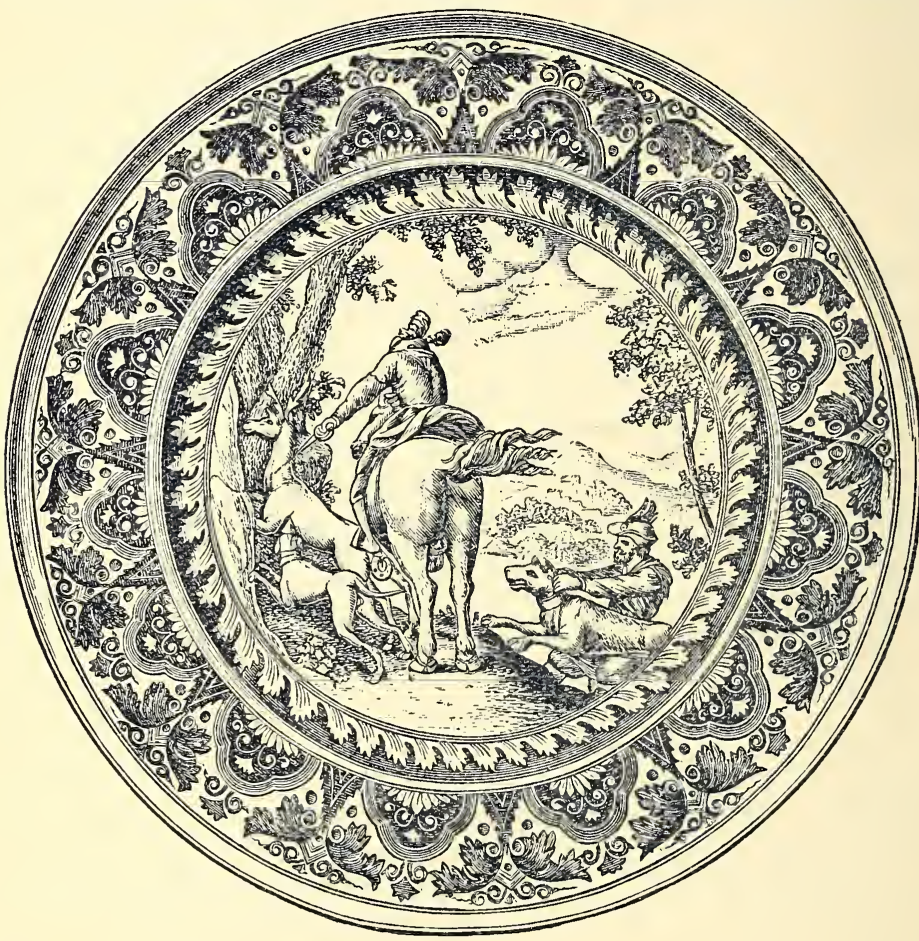
political events, com bin ed to bring about the decline offaïence, and at the close of the 18th century no traces were left of this beautiful industry. (Plate 4, fig. 21 ). Moustiers ware was remarkable for the purity of its milky white enamel, and for the finish and delicacy of the orna$\mathrm{m}$ e $\mathrm{nt}$ a $\mathrm{t}$ i o $\mathrm{n}$, though conceived in a less decorative style than that of Rouen. Our engraving represents a pla-

teau with painted centre, copied from an engraving by Antonio Tempesta, a celebrated Florentine engraver of the 17 th century. (Plate 4, fig. 54.)

Strasburg had also important factories, and the industry there, carried on in face of almost insurmountable obstacles, owes its prominence to the Hannongs. Charles Hannong, a manufacturer of pipes and large stoves, was joined in 1721 by a German named Wackenfeld, who had left the Meissen factory, and they commenced the manufacture of faïence and porcelain. So successful were they that, in 1750 , Hannong's son Paul being then sole proprietor, the manufactory at Vincennes became alarmed, and they obtained an order from the king forbidding Hannong to continue the making of porcelain, and this decree was carried out. The unfortunate potter was obliged to leave Strasburg, but the faience business was continued by his sons Pierre and Joseph. To faïence they adopted porcelain decorations, a departure almost equivalent to the production of a new ware. These delicate decorations, the richness and variety of the coloring and the elegance of the shapes, caused the imposition of a very heavy tax, equal to that imposed on foreign goods, against which Hannong fought in vain. Financial disaster followed, and like his father he had eventually to leave his courtry, and died in poverty a few years later. In addition to tableware, large pieces, such as clocks, 
fountains, etc., exhibiting great skill in coloring and modeling were produced. Our illustration is of a fountain, now in the South Kensington Museum, representing Amphitrite on a shell drawn by a dolphin (plate 1, fig. 15).

These four centres all had their imitators. At first only slavish copies were made, but later they developed some originality. Of the school of Rouen may be mentioned :

Sincenny, founded in 1713. A prominent characteristic was the employment of a beautiful and vivid lemon color. (Plate 4, fig. 41).

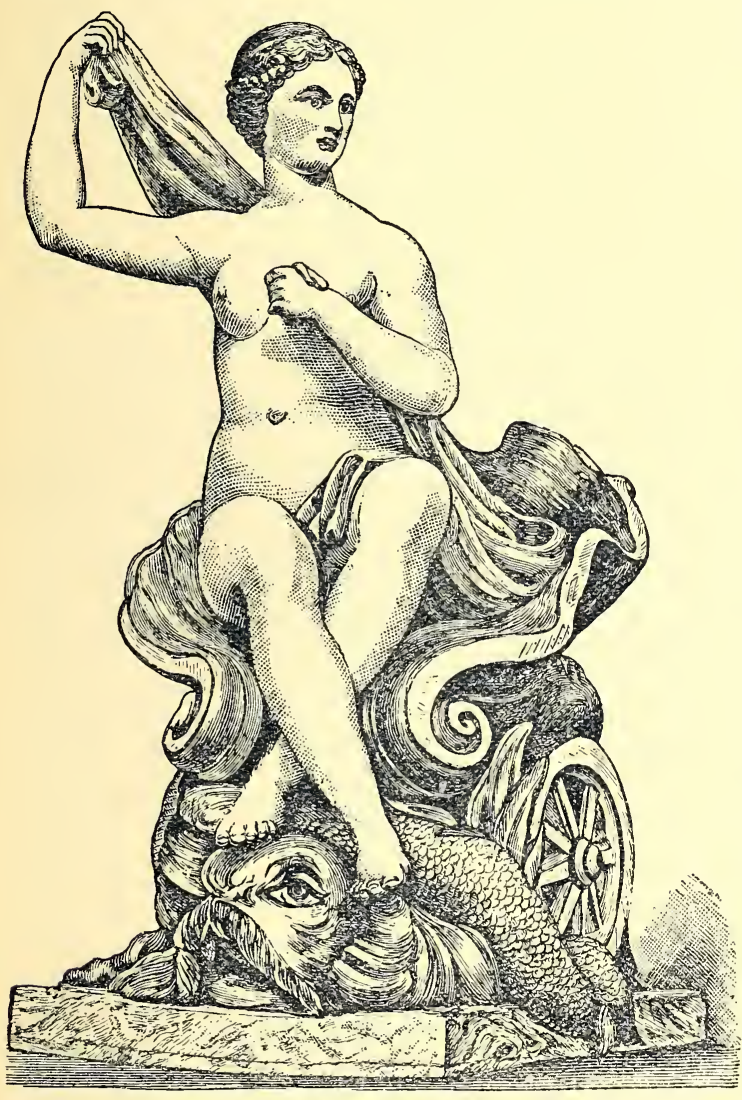

Quimper, under the direction of Pierre Causy. The body was coarse in texture and the enamel gray in tone, the outlines of the decorations roughly traced in manganese. This manufactory was revived by La Hubaudière \& Co.

Lille. Faïence and s of t and hard porcelain were ali made here. The failence manufacture was started in $\mathbf{1 7 9 6 ,}$ by Jacques Feburier, and became important under his successor, François Boussemart (plate 4, fig. 42).

Soft porcelain manufacture was started by Barthelemy Dorez and Pierre Pélissier. The decorations were principally reproductions of St. Cloud, but were more delicately executed, though the body was less white and pure.

Hard porcelain was made under Liperre-Durot, who was the first to employ coal in firing, a piece in the Sèvres museum bearing an inseription to that effect and bearing date 1785. The factory was under the patronage of the Dauphin, son of Louis XVI. (Plate 4, fig. 43).

Of the Strasburg School, the most important was :

Niederviller. Founded about 1742, by Jean Louis de Beyerlé, with the assistance of Strasburg potters. His wife, a woman of excellent taste, supplied many of the designs and equalled in skill the decorators who had been brought from Saxony. Under Beyerlé's management the manufacture of china was introduced. Somewhere from 1774 to 1780 , he was succeeded by Count Custine, who appointed Francis Lanfrey, one of the ablest ceramists of the time, as manager. Under his care it 
gained considerable importance, the china almost equalling Sèvres, the decorations remarkable for their delicacy and taste. The manufacture of faience was discontinued in 1785. A very talented sculptor, Charles Sauvage, generally called Lemire, by his tasteful productions, did much to increase the reputation of the factory. Count Custine fought with Lafayette in the war for Independence. He presented Washington with a handsome service made at his factory, decorated with Washington's coat-of-arms and initials. He also issued a beautifully modeled group of Benjamin Franklin and Louis XVI. During the French Revolution of 1789, Custine was suspected of disloyalty to the Revolutionists because of his aristocratic birth, was tried and found guilty and duly guillotined the same day. (Plate 4, figs. 31 and 52).

Nancy. Founded in 1774 by Nicholas Lelong, who was fortunate enough to secure the services of the celebrated sculptor Clodion, who executed the most charming and graceful statuettes, now so highly prized as to be worth their weight in gold.

Islettes. Started in 1737, survived until 1830. Its principal characteristic was military subjects, painted in brilliant colors and outlined in black.

Aprey. Established in 1750. The productions of Jarry, a very talented bird and flower painter, are much esteemed. The shapes were graceful in the extreme, and were principally copies from models of goldsmiths. (Plate 4, fig. 44).

Marseilles had several factories. That of Savy was visited in 1777 by Monsieur le Comte de Provence, brother of Louis XVI, who authorized the use of the title "Manufactures de Monsieur Frére du Roi." Many pieces broadly decorated with flowers, outlined and shaded in black, were painted over with a beautiful iridescent green, which is not found elsewhere. (Plate 4, fig. 49). Other factories were those of Joseph Robert and the widow Perrin. (Plate 4, figs. 50, 51).

Sceaux, near Paris, was under the patronage of the Duchesse du Maine, and later that of the Duc de Penthiéve, grand admiral of France. It became celebrated under the direction of Chapelle, but reached its zenith under Richard Glot, a clever ceramist and skilful sculptor of ornaments. The faience body is very fine and hard. Figures, flowers, birds and arabesques, are the usual decoration, and are generally enriched with delicately carved ornaments and mouldings. In 1794, Glot sold the factory to Cabaret, but he could not maintain the prestige his predecessor had given the works, and shortly afterwards confined himself to domestic articles. Soft china was also made under Glot, and it was of the same perfect manufacture and delicacy of treatment as characterized the faïence. (Plate 4, figs. 28 and 48). There were also other faïence manufactures at Reunes, Montpellier, St. Amand-les-Eaux, (Plate 4, fig. 53) Orleans and Apt. None of them were of great importance, or call for more than passing mention. At St. Omar figure-pieces were produced in the Bordeaux style, together with vegetable-dishes and soup-tureens in the shape of cauliflowers and other vegetables.

It is necessary to revert for a moment to preceding events before speaking of more modern French pottery. During the existence of the Rouen, Strasburg and other manufactories, the industry had been protected by an almost prohibitory duty on English earthenware, but in 1786 , a new treaty was made between France and England, admitting English earthenware at a duty of twelve per cent. This and the increased production of china in France, proved the downfall of the French faience 
factories, the industry disappeared altogether for a period of sixty years, when faïence again came into fashion, old models and designs were brought into requisition and faïence articles were made and decorated in the style of the last century, so that it was difficult to distinguish the old from the new. English earthenware too was much cheaper and lighter and the shapes much more beautiful.

To avoid confusion the word faïence is used in this article to denote a body covered with an opaque tin glaze; earthenware, a body with a transparent lead glaze.

Under the above mentioned conditions many English potters migrated to France and founded factories there as will be seen from the following brief sketches of the various factories forming the Comptoir Céramique, an oganization recently formed to regulate production and prices. There are of course other earthenware factories in France, altogether, I believe, about 372, but they are either of very small importance, or there were no facilities for obtaining information either as to their history or productions.

Longwy. The industry here was established by the Boch frères towards the end of the last century. About 1839 it passed into the hands of D'Huart de Northcomb, and is now D'Huart frères. Email craquelé was a distinguishing feature and brought the works into prominence. Colored stannifferous enamels of great brilliancy were employed, giving very effective and striking results. This crackle ware has lately been abandoned, or produced very sparingly, but they have yet to demonstrate their ability to produce something as strikingly original and with as much individuality as the émail craquelé. A few staple goods are also produced here.

Montereau. William Clark, from Newcastle, and Ralph Shaw, a Burslem potter, the latter after experimenting at Lille, obtained in 1775 , a subsidy from the Government, and started a manufactory of earthenware and cream color. In 1790 there were two factories at Montereau. In 1810 it came into the possession of De St. Criq, who transferred it in 1829 to Lebauf \& Thiebaut.

Creil was also established by English potters, who made printed earthen ware and semi-porcelain. It was transferred to Lebauf, Milliet \& Co. and De St. Criq \& Co. Semi-porcelain was made until 1860, after which the business was restricted to earthenware. For the present, on account of economic reasons, the factory has been transferred to Montereau. Twenty years ago both factories were at their zenith, but a period of disaster followed, and it has been a stubborn fight to recover their lost prestige. Staple goods only are produced.

Gien. Hall, an Englishman, who had been at Montereau, founded theindustry here in 1820. In 1866 the old works were pulled down and a modern factory erected. In 1870 the factory was devoted entirely, or almost so, to the imitation of old Rouen, Nevers and Strasburg dinner ware by the decalcamanie process, in which they were eminently successful, and specimens are now much sought for. At present ornamental goods only are produced.

Sarreguemines. Founded by Paul Utzchneider in 1770, and is still carried on under the name of Utzchneider \& Co. (plate 3, figs. 33 and 34). To retain its claim as a French factory the firm have recently opened a branch works at Degoin in France. The manufacturers were varied, ranging from china and earthenware to figures and groups in biscuit and Wedgwood Jasper ware, and have always had a high reputation. For the moment they are producing some very effective large 
vases and pedestals in majolica, and are devoting a good deal of attention to Art Tiles.

Choisy le Roi. Messrs. H. Boulanger \& Co. make large quantities of staple goods principally for the Paris market, and some ornamental pieces very decorative in character. (Plate 3, fig. 35.)

Bordeaux Founded in 1714 by Hustin. Its first productions were in the Rouen style. Afterwards large numbers of vegetable dishes in the shape of a bird, generally a turkey or duck, were made, such as are now used as a receptacle for eggs. Of late years ornamental goods decorated in barbotine have been the principal production, but the establishment has been bought out and closed by the syndicate. (Plate 4, fig. 46.)

Lunéville. This important factory was founded about 1729 by Jacques Chambrette. The style of Nevers and Strasburg was followed and an almost instantaneous success resulted. To such proportions did the business grow that Chambrette built two other factories, one at Lunéville and the other at St. Clement, six miles distant. King Stanislas had been a patron of the works, and upon the death of Chambrette, in 1858, when the business came into the hands of his son and sonin-law, Charles Loyal, the king confirmed the privileges aiready granted and gave to the pottery the title of Manufacture Royale. About 1772, the prosperity of the three factories began to decline, Chambrette became bankrupt and the management of them devolved upon Loyal. In the St. Clement factory he gave an interest to Cyfflé, the sculptor, but his means were soon exhausted and in 1778 he sold the two Lunéville factories to Sébastien Keller, whose direct descendants are now the proprietors. He kept on the St. Clement works for some time but had finally to surrender it, and after undergoing many experiences, in 1824 it came into the hands of Mr. Germain Thomas, under whose skilful direction the adverse tide was turned. It remained in his family until 1890 , when it was purchased by Keller and Guerin, a son of Mr. Thomas continuing as its director.

The Lunéville factories owe much of their importance to the sulptor Cyfflé, the author of many charming and greatly admired statuettes. Cyfflé went to Lunéville in 1746, where he was entrusted with several important works by the king's sculptor, but these were large allegorical subjects, and were not to his liking, and he soon devoted himself to small statuettes, generally depicting scenes in humble life, such as "The Cobbler Whistling to his Starling," "The Savoyard Chimney" sweep," "The Gardener and his Wife," and such like subjects. He was of a free and easy nature, fond of the wine shop, and was at his best when reproducing popular scenes and types. His sense of humor was of the keenest, "his knowledge of modeling, truthfulness, skill and delicacy of touch were essentially typical and personal and imparted value even to his least important works." His profligate life prevented him from acquiring the wealth his talents entitled him to, and he died at Bruges, his native city, in 1806, in poverty and obscurity. His statuettes were always in white and are known as terre de Lunéville. Many of the original moulds are still in the possession of Keller and Guerin. They were at one time reproduced by them, but it is some time now since any have been issued. The Bellevue Pottery had some moulds made from casts of the original, but the Lunéville statuettes alone are marked, impressed in the clay

Cyfflé 
They have in France a proverb : "Se regarder comme des chiens de faïence" (to stare at one another like crockery dogs). Lunéville produced large fäience pieces in the shape of huge dogs, and it became the fashion to place one of these on each side of the door, and hence the proverb.

To have carried the factory successfully through the troublous times at the close of the last century, is evidence of no small ability on the part of Mr. Keller, especially as he had begun to develop a higher class of wares, a development admirably carried out by his son, the present proprietor and his partner, Mr. Guerin. The present productions at Lunéville are so varied that we can only here briefly glance at one or two of them. Staple goods are produced in abundance and of an infinite variety, bowls and cups and saucers predominating. Turning to the higher branches of art, we find a varied collection of ornamental goods in which pieces of heroic size predominate.

A vase with thistle decoration is over five feet high and is enriched with a luminous sea-green glaze. This decoration is also applied to a variety of shapes and sizes. There are many reproductions of the best specimens of the old Rouen and Strasburg faïence, carefully executed, both in technique and design. Vases, both large and small, with flower subjects painted on the wet clay and covered with a warm reddish brown glaze of exceeding softness and apparently inexhaustible depth, rivet your attention, and you are undecided whether the charm lies in the exquisite modeling and drawing of the flowers, or whether there is not some suggested quality you can hardly define.

A few months ago Messi's. Keller and Guerin discovered the secret of producing what is termed reflets metalliques. It is difficult to describe exactly the effect produced. The piece, whether it be vase or placque, is painted with various metallic oxides, principally copper and silver, and during the process of firing, artificial currents of air are introduced in the kiln, which causes a partial crystalization of the oxides in the pigments, leaving a beautiful metallic deposit of so iridescent a nature that the painting presents almost kaleidoscopic changes of color when seen in varying lights. No two pieces are alike, so there can be no duplicates. They are the only firm who produce these reflets metalliques on earthenware. (Plate 3, figs. 37, $38,39)$.

Montagnon of Nevers shares the honors with the above house in his reproductions of old French faience.

Clement Massier, Golfe Juan Pottery in the south of France, produces mostly large jardinieres and pedestals, in glazes suggestive of lapis lazuli, cornelian and agate. The pieces are all splendidly potted and the glazes are veritable triumphs. No words can do them justice. They must be seen to be appreciated. M. Massier was the first to re-discover the reflets metalliques, applying the process to faïence.

Of recent years no one has done more for the Ceramic Art than Théodor Deck, of Paris, and France may justly be proud of him. Of pure and delicate taste, he has overcome, one by one, all difficulties, whether the revival of that splendid carnation red, the secret of which was previously known only to the potters of the East, the re-discovery of Chinese enamels, or the imitation of Faience d'Oiron. With the help of the best artists obtainable, he has founded a distinct style of his own, a style that future generations, no less than that of to-day, will recognize as representing all that is noblest in the Ceramic Art. 


\section{France= Porcelain .}

\section{(St. Cloud-Chantilly-Vincennes-Sèvres.)}

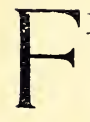

RENCH CHINA is of two kinds, pate tendre (soft or artificial porcelain), and pate dure (hard or natural Kaolonic porcelain). The importation of Chinese porcelain into Europe stimulated the potters of every country to discover its properties, or make an imitation of it. Although no specimens are known, there is documentary evidence that artificial china was made in Venice about 1470 : the first dated example being a piece of the celebrated Medici porcelain (plate 1, fig. 9) made at Florence, and dated 1581. Nearly a hundred years afterwards -in 1673-a patent was granted to Louis Poterat, a faïence manufacturer of Rouen, for the production of porcelain. Some pieces, undoubtedly of his manufacture, are in existence, but he does not appear to have followed up his first success (plate 1, fig 6). Possibly the production was attended by too great a loss, or his faïence business demanded all the attention he could bestow upon it. Be this as it may, the first factory devoted to its production was the one established at St. Cloud, in 1675 (plate 1 , and plate 4, fig. 36). The porcelain produced there was "of a fine milky white

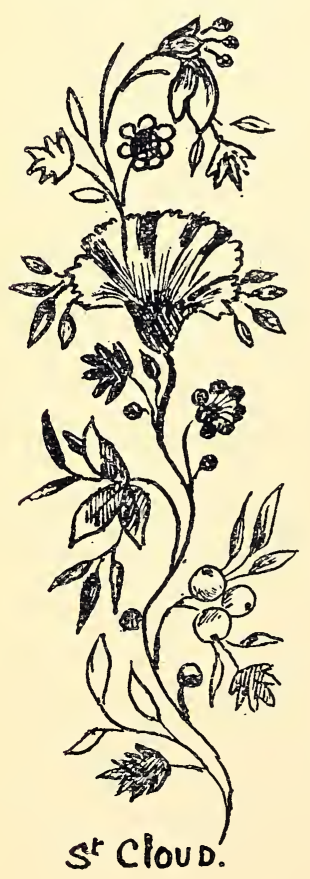
color, of a soft and warm appearance, very transparent and very tastefully and carefully decorated with lambrequins, or arabesques in the pure French style, or with subjects in colors imitated from old Chinese and Japanese patterns." The factory was burned down in 1773 , and was not reconstructed.

The Chantilly Works were founded in 1725, under the patronage of the Prince de Condé, and evinced a great improvement over St. Cloud in the character of the decorations, on account of the greater simplicity of its products, principally copies of Imari ware. Corean decorations, of which the prince had a fine collection, were also copied. Like the Medici china, elsewhere described, the Chantilly ware was covered with a thin tin glaze, which was productive of very harmonious and delicate tones in the decoration. After the death of its founder, the character of the work deterioated (plate 1).

In the meantime at Vincennes, two brothers named Dubois, formerly employed at St. Cloud and Chantilly, in conjunction with the Marquis Orry de Fulvy, commenced in 1740 to manufacture there; but after several years of long and costly experiments whose failure was due to their want of skill, the brothers left and were succeeded by their assistant, Gravant. By careful management and application, matters had progressed so favorably that in 1745 they were able to show results of such merit as to determine the ultimate success of the works (plate 1). A royal 
subsidy was granted, the king, the dauphin and the Marquise de Pompadour, took a great interest in the factory, and porcelain became quite fashionable. Stringent laws were passed to protect the industry and preserve the secret of the composition of the body, though, as far as the latter is concerned they were unavailing. As has been stated before, hard porcelain is composed of Kaolin and pe-tun-tse; whilst the composition of the Vincennes china consisted of Fontainbleau sand, saltpetre, soda, alum and gypsum, or parings of alabasier. This was fired for fifty hours and formed a frit, or vitrified paste. After grinding, it was mixed with a coarse clay in the proportion of nine to three, and the paste thus obtained was kneaded by machine and made plastic with soap and boiling water. This was then fired, and was ready for the application of the glaze, composed of Fontainbleau sand, litharge, salts of soda, Bougival silex and potash, melted in a crucible and pulverized. To make it adhere to the body, vinegar was added. After firing, the ware was ready to receive the decoration. Pate tendre "is so composed in body and glaze that it alone of all ceramic wares can perfectly assimilate itself with colors, in such a manner as to present to the eye the appearance of one surface. In the case of French porcelain or English faience it is always possible to separate the colors from the body. In the case of pate tendre, on the other hand, no such distinction can be drawn. It is impossible to separate the one from the other." It is this feature that renders it possible to distinguish it from English china, which it greatly resembles in transparency and color. The appellation of pate tendre was only applied to artificial porcelain in the early part of this century, until then it was known as French or Sèvres porcelain. It is a misnomer however, as the body is much harder than the glaze.

In 1753, upon the death of the Marquis de Fulvy, the king took one-third of the shares and officially gave the works his patronage, authorizing it to assume the title of the Royal Manufactory, with instructions to mark all pieces produced with his monogram. The business increased to such an extent that the premises at Vincennes were no longer adequate to its requirements, and, accordingly in 1756 , the plant was transferred to

\section{Sèvres.}

Up to this time, in addition to the flowers modeled in relief, for which the manufactory was so celebrated, vases with bleu de roi and rose Pompadour grounds (sometimes erroneously called hose $d u$ Barry); a large variety of fancy articles, and table services decorated with exquisite minute paintings; and groups and figures skillfully executed from designs by Boucher and Vanloo were produced. Greater manufacturing successes followed, but disagreements ensued among the promoters and it was dissolved in 1759, the King becoming sole proprietor. Boileau was maintained in his position as director. The manufactory having been established to nullify foreign competition, eagerly accepted the offer of two German workmen, Busch and Stadelmeyer, to disclose the secret of the Meissen china. But as their process depended on the employment of materials not found in France and which would have to be imported at great expense, their services were dispensed with. Macquar, a chemist of the establishment, was strongly of opinion that Kaolin existed in France, and it was eventually discovered at St. Yriex, near Limoges, by Madame Darnet, the wife of a poor country surgeon. Unfortunately Boileau did 
not live to reap the benefit of this discovery, as he died in 1773 . He left 300,000 livres in the coffers of the works and other assets for a similar amount. This large sum was entirely squandered by his successor, Parent, in less than six years, his brief but expensive directorship ending in a prison, to which he was sent for reckless mismanagement. Regnier, the sub-director, succeeded him and the manufacture of important works in pate dure was carried on so successfully that in 1789 Sèvres stood without a rival. About this time jeweled porcelain was first made. Political events and private competition, which robbed Sèvres of its best workmen; the great revolution and overthrow of monarchy brought troublous times to Sèvres, and it was

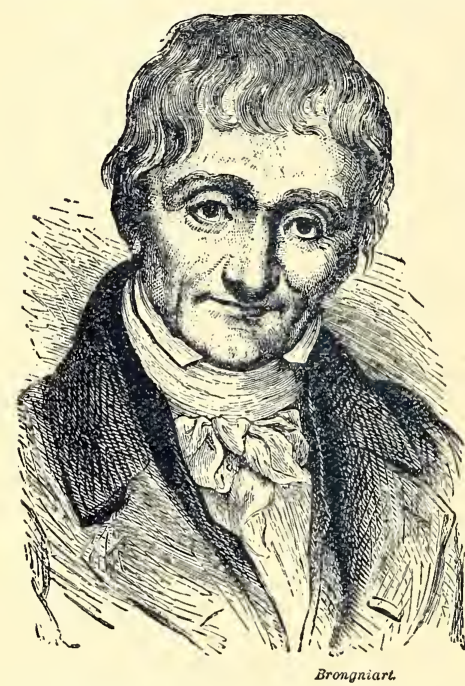
not until 1808 that the resulting arrears were definitely settled. Under the Directory the administration was vested in Salmon, Hettlinger and Mayer, who were succeeded in 1800 by the illustrious Alexandre Brongniart, whose name will for ever be associated with Sèvres. Under his management it was not only a royal manufactory, but it became a public benefaction, realizing more than ever its mission as setting an example and encouraging private enterprises, without competing with them. During this period, by the decree of 1753 , all pieces had been marked with the cross L's, with the addition of a letter: A for 1753 ; $\mathrm{B}$ for 1754 , \&c.; $\mathrm{Z}$ for 1776 , when double letters were commenced and continued until $R$. R. 1793. The mark was then changed to Sèvres with the initials R. F. below, which was abandoned in 1800 and the word Sèvres alone remained.

In 1801 the use of letters was resumel as follows :

$\begin{array}{lcrrrrrr}\text { T9 } & 1801 & -\|- & 1805 & 9 & 1809 & \mathrm{tz} & 1813 \\ \times & 1802 & \hat{\dot{ }} & 1806 & 10 & 1810 & \mathrm{qz} & 1814 \\ 11 & 1803 & 7 & 1807 & \mathrm{oz} & 1811 & \mathrm{qn} & 1815 \\ =:= & 1804 & 8 & 1808 & \mathrm{dz} & 1812 & \mathrm{sz} & \mathbf{1 8 1 6}\end{array}$

and a printed mark-from 1804 to 1809 -added, (manufacture impériale de Sèvres, 1806). In 1810 the Imperial eagle was used and then followed the marks given on plate 1 .

These marks were all kiln marks, but in 1848 an underglaze mark was adopted bearing the monogram L. P., but it was soon replaced with an oval with the letter $\mathrm{S}$ and date of manufacture. This mark was suppressed in 1878 , but resumed in 1879. When cut through it indicates that the piece was not decorated at Sèvres. M. Brongniart decided that no more pate tendre should be made at Sèvres, and in 1804 , sold all the undecorated white ware at very low prices to Paris decorators and others, who were not slow to avail themselves of the advantage offered them. If this was on his part an error of judgment he amply atoned for it by the reforms he instituted and carried out, setting the example himself by accepting 3,000 francs instead of 6,000 ; the amount fixed for his salary. He secured the gratuitous services of many eminent artists to furnish designs, and by 1804 had made the factory self-supporting, when it became the entire property of the Emperor. In 1832 
he organized the unique Museum at Sèvres, today a lasting monument to his memory. Under his management vases nearly eight feet high were made on which were painted copies of the most celebrated works of the day, to perpetuate the chief events in the life of Napoleon I; large busts of the Emperor and of the two Empresses; elaborate table services with borders of war trophies; statues of fame and Egyptian monuments, all told of the Emperor's victories. The taste of such productions may be open to criticism but their execution is beyond dispute. Brongniart died in 1847, the crowning glory of his life being the writing of his Traité des Arts Céramiques, in which all the Sèvres processes are minutely described. The Royal factory undoubtedly exercised a very great iufluence and it is not too much to say that every progress made for the last hundred years in French Ceramic art is almost entirely due to Sèvres. Let us cite a case : The failing fortunes of the earthenware factories were brought to Brongniart's notice and he immediately placed the whole resources of the factory at the disposal of M. de St. Amans, in his endeavor to save those interests from ruin, in which he was happily successful. Brongniart was succeeded by Ebelmen, who died five years later, and in turn Regnault was appointed director. On account of family afflictions he resigned during the Franco-Prussian war and was succeeded by Louis Robert. The Paris Exhibitions of 1874 and 1878 bear evidence of his efficiency. He died in 1882, and M. Lauth, a chemist

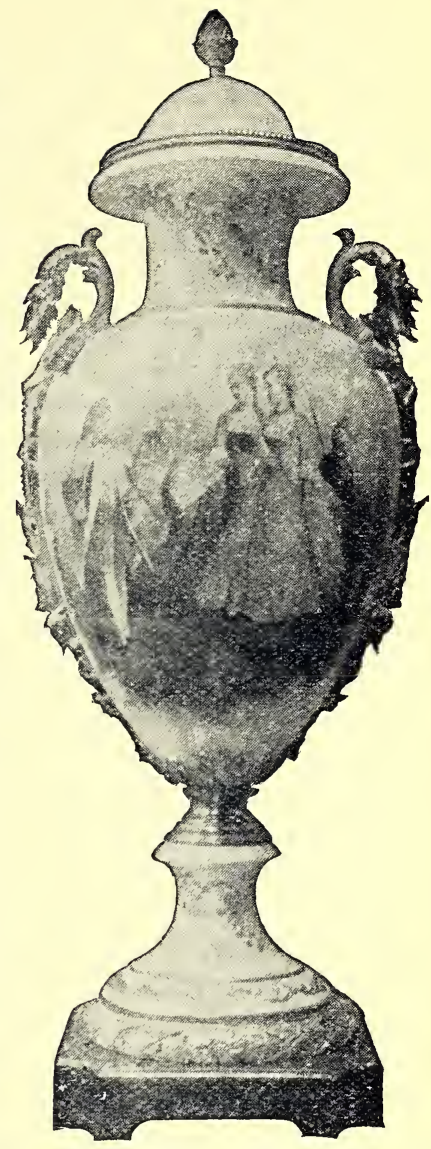
and member of the Paris Municipal Council, succeeded him.

Towards 1850 Louis Robert introduced the process of Pâte sur pâte painting. It is difficult to exactly describe what this is. It is not strictly speaking painting, nor yet is it modeling, but a blending of the two. Many difficulties presented themselves; there were tremendous losses ; but at the London Exhibition of 1862 a very successful set of cups were shown. Salvetat, the distinguished Sèvres chemist, by his experiments did much to reduce the difficulties. The simplest form is a decoration with white slips on a ground to which coloring oxide has been added, the modeling being produced by transparency according to the thickness of the slip or paste. M. Solon exhibited some successful pieces at the Paris Exhibition in 1867, but after the war he went to England, and from the Minton factory issues the most graceful and poetic fancies created by his pure and lofty genius. 


\section{French China. (Continued.)}

Mennecy. Under the patronage of the Duke de Villeroy, in 1735, this factory was founded by Francis Barbin. The styles of decoration were very varied, ranging from the simple designs of Chantilly to the more ornate decorations of Sèvres. (Plate 4, Fig. 26.)

Orleans. In the same year Gerault established a factory at Orleans. Flower paintings and biscuit figures were produced. (Plate 4, Fig. 29.)

Paris. At La Courtille, (see Pouyat,) Jean Baptiste Locré produced fine hard porcelain, very translucent and the glaze soft and even. The factory was established in 1773. (Plate 4, fig. 30).

At Clignancourt, in 1775, Pierre Deruelle produced soft porcelain, under the patronage of the brother of the King (Count de Provence) (plate 4, figs. 32, 33). The factory in the Rue de Bondy, founded in 1780, was under the patronage of the Duke d'Angoulém - and produced vases of great beauty (plate 4, fig. 34), while that of Pont aux Choux, founded in 1784, two years later came under the patronage of the Duke of Orleans. (Plate 4, Fig. 35.)

Limoges. Considering the importance of Limoges as a large china-producing centre, it scarcely seems to have received the attention it deserved by writers on ceramics. The earliest factory of which we have any information was founded by Sieur Massier, in 1737, as a faïence manufactory. A large dish in the Sèvres Museum painted in green with a stag-hunting subject, is marked "Limoges, 1741," and there is a dish with the same mark in the Limoges Museum. Soon after the discovery of kaolin at St. Yrieix the factory was converted into a china manufactory. This was in 1773 . In 1784 it was absorbed by Sèvres, Gabriel Grellet acting as director. He was succeeded by Francis Alluaud but the arrangement did not work altogether satisfactorily, anc. in 1793, Sèvres relinquished the control and it again passed into private hands, the new proprietors being Joubert and Cancate. In 1797 Francis Alluaud started the Casseaux works and he had also control of one of the kaolin mines. In 1858, Charles Field Haviland, an American, married a granddaughter of the original proprietor, thus uniting the old and new regime, and ten years later he succeeded $\mathrm{Mr}$. Victor Alluaud in the direction of the factory. M. Alluaud the founder was mayor of Limoges in 1792, and author of several important books. History also names him among the members of Tiers état, giving him title of "Director of the Royal Porcelain Factory at Limoges." This refers to the time when Sèvres controlled the Massier factory. IIis son, François, was also mayor of Limoges in 1833. He received the cross of the Legion of Honor, with the title of Chevalier in 1832, and was decorated with the "Rosette d'officier" in 1858 on the occasion of the visit of Prince Napoleon to his factory.

The Baignol factory seems to have been the principal one in Limoges during the first Empire. In 1844 Brongniart, the celebrated Sèvres director, wrote that the china produced in Limousin formed more than three-quarters of the entire French production. 


\section{J. Pouyat.}

$\mathrm{T}$

HE Pouyat family have long been identified with the city of Limoges, and its citizens have freely conferred on them the highest honors within their gift. Pierre Pouyat, who was consul in 1743, established in 1760 a faïence manufactory at St. Yrieix, and specimens are still occasionally met with in the Département Haute-Vienne, marked with a capital P. This factory was in full operation at the time of the discovery of kaolin at St. Yrieix, and Pouyat at once recognizing the value of the discovery bought a bed of the finest quality. Paris was then the best market for china, and there were established there four or five factories, the principal one of which, La Courtille, near Fontaine au Roi, Mr. Pouyat purchased. Hard porcelain was already produced here but under German influ. ence and dominated by German taste. To change the whole style of production of a factory witb an already well-established reputation (it was founded in 1773 by J. B. Locre) required some courage, but Mr. Pouyat did not shrink from the task, his object being to found a distinctively French industry. Success seems to have come quickly and to Mr. Pouyat must be ascribed the credit of having made in body and composition, from native material, the first French hard porcelain. Specimens of the old pink and blue "Barbeau" pattern of La Courtille are eagerly sought for and are known as "Old Pouyat."

At La Courtille they were the first to

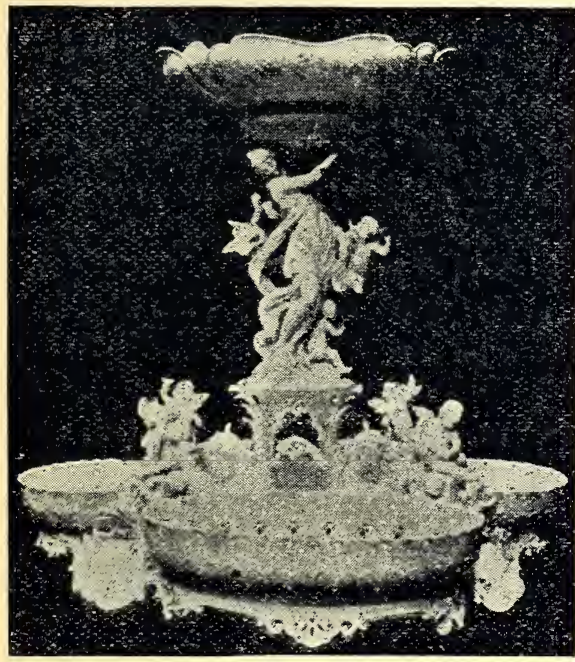
employ grand feu colors, not only blue, but also a brown known as ecaille and a violet. The coulage or casting process was known and practiced as early as 1791, while it was not adopted at Sèvres until 1814. For his services to French Ceramic Art Mr. Francois Pouyat received in 1830 the cross of the Legion of Honor. He died in 1838, aged 86 years. His son, J. Pouyat, who had been his partner and active collaberature, succeeded him. $\mathrm{He}$ founded in Limoges, in 1842, a factory which soon assumed considerable importance, gathering around him the best workers then to be found, and aiming at and effecting a high standard of excellence in the goods manufactured. He was succeeded by his sons, Emile, Louis and Eugéne. To such extensions had the business grown that it became necessary to build a new factory to keep pace with the demand and this was accordingly done in 1849 when the St. Leonard's Works were erected. The Pouyat china is remarkable for its fine texture, and such confidence had the firm in its excellence that at the Paris Exhibition of 1855 and the London Exhibition of 1862, they had the courage to make a specialty of their white ware without calling in the decorator's aid, content in the assurance that it would best indicate that for which they had always striven, viz : purity of body and glaze and artistic excellence in design. Nor was this 
confidence misplaced, as in each case the highest possible award was bestowed upon them. Especial attention was attracted by the thinness and lightness of the cups, which won them the name of Tasses mousseline and which has since become a generic term to denote extremely thin cups. It was for these same qualities that the first prize was awarded to them at the Paris Exhibition of 1878, and Mr. Dubreuil, sonin-law of Mr. Louis Pouyat and manager of the factory, was created a Chevalier of the Legion of Honor.

In 1890, Mr. Emile Pouyat, who in spite of his great age had always participated in the active conduct of the works, entrusted the management to his grandson, Baron de la Bastide, and Mr. G. Dubreuil, grandson of Mr. Louis Pouyat. While paying special attention to their white ware, so distinguished for its thinness and translucency, many beautiful decorations come to us from the Pouyat factory. One of the Pouyat specialties is the excellence of their underglaze (frand feu) Sèvres blue, which the chemist from the Sèvres factory attributes to the quality of the clay which is peculiarly adapted to the assimilation of cobalt. Mr. Charles Laurent is the manager of the painting department and his facile pencil enriches many of the ornamental pieces with finely conceived and delicately executed flowers and figure subjects. Mr. Beylac, a skilful modeler, is responsible for many of the really very fine shapes produced.

Our illustration is of a white china centre piece representing the four seasons, presented by the firm to the New York Metropolitan Museum of Art. The base is 40 by 36 inches, and the height 36 inches. It is a good example of the Pouyat china and an excellent specimen of modeling. Only four of these were made. One is in the Sèvres Museum, another in the one at Limoges and the third one is retained at the factory.

The firm upheld their reputation at Chicago by carrying off the highest award in the power of the jury to bestow. (Plate 2, fig. 7.)

\section{Haviland \& Co.}

$\mathrm{T}$

HE sight of a piece of enameled faience altered the whole course of the life of Palissy ; the importation of a French china tea set to America revolutionized the trade of Limoges. The introduction of the manufacture of porcelain in Europe owes its inception to the weight of a wig. And of such trifles is history made. When in 1839 Mr. D. Haviland, who was an importer of English earthenware in New York, saw the tea service referred to, it appeared to him so superior to the wares he was importing that he decided to introduce it here. There was no mark to guide him, nor could he obtain any information about it, but he was not easily to be discouraged, and with the sole knowledge that it was made in France, he started out to solve the problem. Eventually his enquiries led him to Limoges, and though the search was ended, his work had but begun. The shapes and decorations were limited and unsuitable for this market. Accordingly he set to work and furnished to the factories there, patterns of plain services, then only made in England, and while they were executing his commissions for white ware 
he organized large decorating shops, employed pupils and skilled professors, and in this modest manner started a business destined to grow not only to colossal proportions, but to represent a standard of excellence synonomous with all that is best and truest in ceramic art. This radical departure caused something very near approaching a riot in Limoges, and for a time pupils and professors could only go about in bands, in order to protect themselves from assault. In 1840 Haviland \& Co., initiated the exportation of French china, and though the first four years only averaged about $\$ 100,000$ per annum, in 1880 the average amount had increased to $\$ 1,400,000$.

When Mr. Haviland from decorating only, turned to manufacturing, it was with facilities largely in advance of anything then existing at Limoges. Plates are now made entirely by machinery, enabling them to turn out about 11,000 per day. And while other labor-saving devices were adopted, that the artistic element was not neglected is evidenced from the fact that as early as 1885 two hundred decorators found employment there.

In 1873, at Bourg-la-Reine, Messrs. Chaplet, Laurin and Lafond discovered a new process of decorating earthenware, and Haviland, quick to perceive its value, secured the services of M. M. Chaplet and Lafond. The process, very briefly, consists of decorating the wet clay before it has been fired, somewhat after the manner employed on early Italian pottery, but yielding results much superior in detail and softness. Miss Young in "The Ceramic Art," describes at length all the most important works produced from the Haviland studios, and to her interesting work the reader is referred. (Plate 2, fig. 6).

\section{E. Gérard, Dufraisseix \& Co.}

\section{(Charles Field Haviland.)}

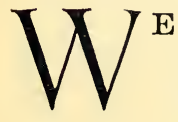

$\mathrm{E}$ have seen in our brief sketch of Limoges something of the history of the old Alluaud factory, and it is therefore needless to recapitulate it here. Mr. Charles Field Haviland went to Limoges in 1851, and in 1859, commenced to decorate china. Consequent upon his success, in 1861 he enlarged his sphere of action and began its manufacture, catering principally for the American market. In 1868 he assumed the entire control and direction of the

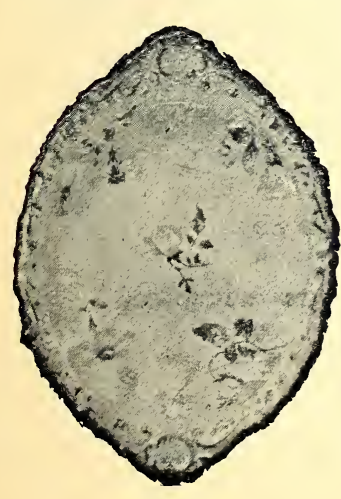
Alluaud factory, continuing its management until 1881, when he relinquished the active control. He remained a special partner until his death, which took place June 12, 1896. He was succeeded by E. Gérard, Dufraisseix \& Morel. M. Gérard had long been identified with the china industry at Limoges, and, under his management, the growth of the firm has been most gratifying. The large factory soon became inadequate to meet the demands for its productions, and, during 1892, it was entirely remodeled and large additions made, so that its productive capacity is now nearly fifty per cent. greater than formerly. This phenomenal growth may be accounted for by improvements in the body; the production of artistic designs in both 
shapes and decorations; the employment of the most modern machinery, and the best available talent, and to the general esprit du corps which M. Gérard infused throughout the whole of the manufactory by his appreciation of the importance of small things, his unfailing energy and consummate skill.

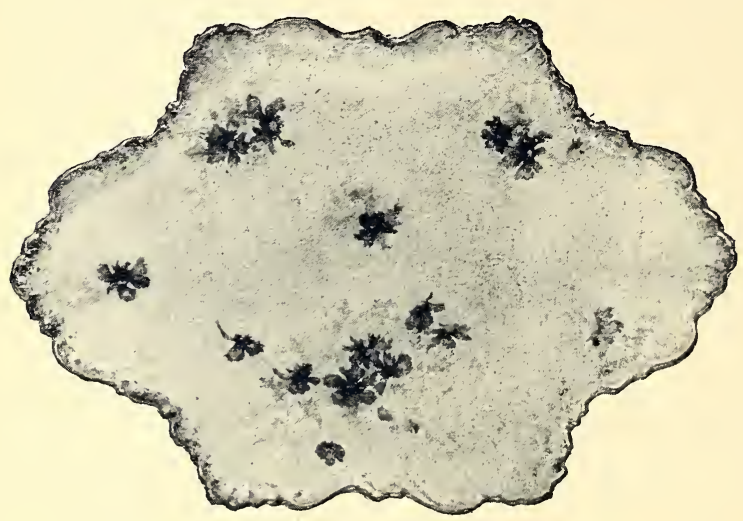

Their exhibit at the World's Fair was an evidence of the progress made by this house, including as it did many examples of feu de four which necessitate the employment of colors requiring the same degree of heat as the body itself, by which means the closest possible affinity is secured. Hitherto such results had been but imperfectly realized; the colors had been sombre in tone, and the process an expensive one. We may therefore feel justified in regarding the employment of bright colors which Messrs. Gérard, Dufraisseix \& Co. have successfully produced, suitable for the decoration of tableware, which necessarily demand such, as a distinct advance in ceramics. The result is a beautiful softness, the colors so assimilated with the glaze as to render it almost impossible to separate them. It is this affinity of color, body and glaze that constitutes the charm of Sèvres' Pâte tendre.

The C. F. H. china is so well known as to render criticism superfluous. The best efforts of the firm are devoted to articles of utility, which they are constantly laboring to improve, not only in the decoration, but in gracefulness of shapes. To-day, the old Alluaudfactory, its conservatism but a tradition of the past, is one of the best equipped and most progressive in the world. The trade marks and dates at which used are :

Prior to 1868

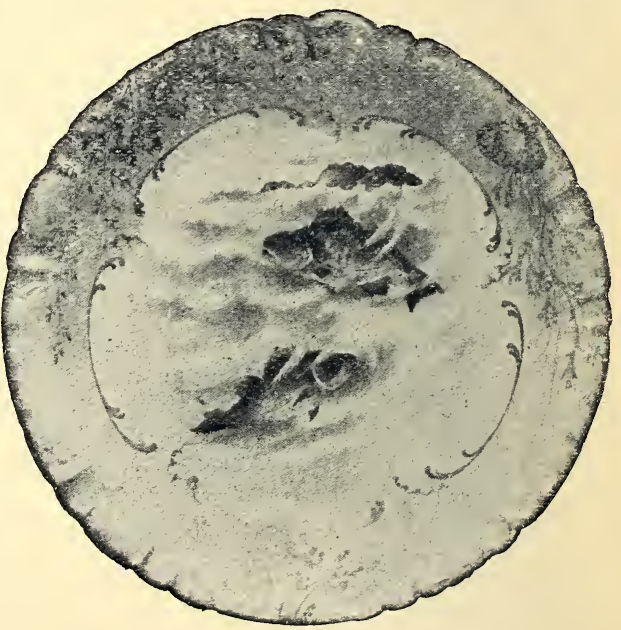
E.........stamped in the clay.

1872 to 1882 C. F. H.

1882 to 1891 C. F. H.

G. D. M. “ " “ “

The word "France" was added in 1891

The decoration stamp has always been "Ch. Field Haviland, Limoges," in a circle. (Plate 2, fig. 1). 


\section{Other Limoges Firms.}

Theodore Haviland. Much of the success that attended the firm of Haviland \& Co. was due to the active share taken in its management by Mr. Theo. Haviland. January 1, 1892, the partnership was dissolved, Mr. Theodore retiring from the old firm, which was reorganized as a stock company. Another stock company, with Mr. Theodore at its head, was formed, and they erected an entirely new factory with all the most modern improvements, organized an efficient staff, and were quickly in the field with an extensive assortment of shapes and decorations. The success of the enterprise is now assured, a condition that could hardly fail to result from the quality and character of the goods produced. (Plate 2, fig. 11).

The house of Delinieres has been established about fifty years, but prior to 1881 they only made white china. In this year they added a decorating department, giving especial attention to ornamental goods of which they make a large variety. They have been very successful in their treatment of blue underglaze, their artists producing some very effective and harmonious results. Mr. Delinieres, the founder of the factory, has been decorated with the cross of the Legion of Honor, and is also one of the directors of the Sèvres factory. Up to 1893 the mark plate 2 , fig. 2 , was iused, figure 3 being the present mark for white ware and the name "R. Delinieres \& Cie., Limoges," in small script in red, when a decoration is added.

Mr. J. F. H. Vogt, in 1852, founded a manufactory of china and this gave place in 1882 to the new firm of Tressemanes \& Vogt. They make a general line of useful goods and the bell trade mark is favorably known, whilst the initials T. \& V., have long been accepted as a guarantee of the quality of the body. Rapid developments have been made in decorations within the last few years. (Plate 2, fig. 50.)

Mr. A. Lanternier, who spent a considerable time perfecting himself in English and in learning the pottery business with Messrs. Wedgwoods, of Etruria, commenced manufacturing at Limoges in 1885. His father had formerly been engaged in the decorating business there. Perhaps the youngest of the Limoges manufacturers, Mr. Lanternier has succeeded in placing himself amongst the foremost in the race, his shapes being particularly pleasing, whilst his white ware is undoubtedly of very superior quality. (Plate 3 , fig. 36).

The house of L. Sazarat Co., is an old established one, which until a few years ago was scarcely known in this country, but by adapting themselves to our particular requirements they are now coming to the front. Their decorations are particularly soft and harmonious. M. Sazarat has been decorated with the Cross of the Legion of Honor and at all the French exhibitions since 1855, has been awarded a medal. (Plate 2, fig. 8). 


\section{Italian Majolica.}

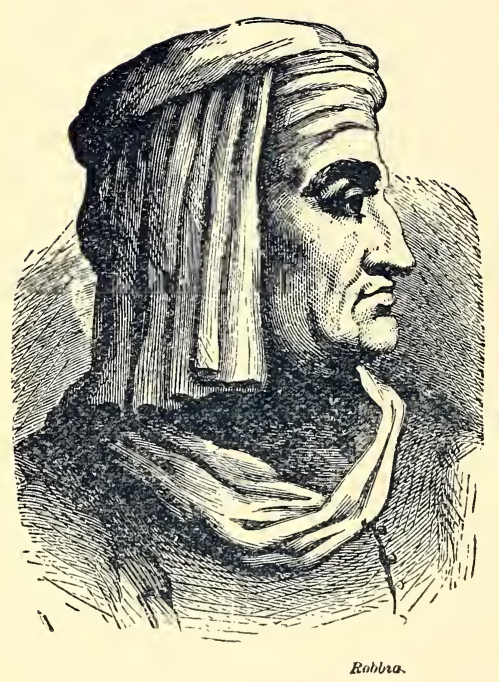

FROM the remote period when the Egyptian and other Eastern nations used a stanniferous glaze to hide the coarseness of the ware it covered, all trace of it appears lost until 1235, A. D., when the Moors founded the Kingdom of Granada. Granada and Malaga were the seats of the manufacture of the Hispano-Moresque pottery, and it is probable that the celebrated Alhambra Vase was made there. It was found in the 16 th Century under the pavement of the Alhambra, which was built in 1248. This vase is decorated in blue and gold lustre with arabesques and panels on which two antelopes are figured, on a whitish, fleshcolored body. It was copied at Sèvres, in 1842, and later by Deck, of Paris, the latter copy being now in the South Kensington

Museum. There are continuous examples of this ware down to the Conquest of the Moors by Ferdinand and Isabella in 1492, when the style became more purely Spanish and soon afterwards began to decline.

The estimate placed on this Hispano-Moresque pottery seems above its merit and even its lustre for which it is chiefly remarkable, was excelled by Giorgio. Popular tradition ascribes the introduction of majolica into Italy as follows:-

"The men of Pisa once upon a time undertook to clear the Tyrhene Sea from all Mussulman corsairs. There was at that time an infidel king, Nazaredeck by name, who busied himself cruelly about the cuasts of France and Italy. Twenty thousand Christians were said to be imprisoned in his dungeons. In the year 1113 the Archbishop of Pisa preached a crusade against Nazaredeck, exhorting the people to open the prisons of their Christian brethren and to deliver them out of the power of the infidel. It was not however until two years later that Majorca was taken, the king was killed, his son made prisoner and carried with great spoil and booty to Pisa. Among the spoil were many plates of Moorish pottery, which the Pisans stuck into their church walls as trophies and ornaments. For two hundred years this pottery was regarded as only a thing of beauty and to be venerated as a religious symbol, and it was not until the beginning of the 14th Century that the Italians began to make an imitation ware which they called majolica."

The matter is one apparently of surmise only, and the authorities are by no means unanimous. The argument is advanced that Danté wrote "Cipri e Maiolica," showing the then mode of spelling the name cf the Island, but are not the letters I and $\mathbf{J}$ freely interchangeable in Italian in proper names? It is certain that previous to Luca della Robbia's discovery, ware covered with a white slip and finished with a metallic lustre were made at the potteries of Pesaro or Gubbio, and these were later called Mezza Majolica to distinguish them from the tin enameled and lustred 
majclica. Towards the middle of the 16th Century the word began to be used for all glazed earthenware. Another early form was graffito, in which the ware is covered with a white slip and is then scratched through with an iron tool, showing the design on the colored body beneath.

But the principal interest in Italian Majolica centres in Luca della Robbia (A. D. 1400-1481), a sculptor of eminence who wishing to protect his terra cotta figures, invented a tin glaze, much superior in quality to anything before used, and if he was not the originator in Italy, it is certain he made such a decided forward movement as to give him the same position in Italy that Wedgwood occupies in England, Palissy in France and Böttger in Germany. He utilized his discovery for painting as well as scuipture, and his earliest dated piece is 1438 , as it is also the earliest dated of any Italian tin enamel ware. The secret of its manufacture was bequeathed to his nephew Andrea, who in turn transmitted it to his four sons, but the purity and simplicity of the style of Luca was wanting. The secret leaked out and workshops were established all over Italy, many of which rose to prominence. During the first period the decoration was painted on the unfired enamel, and as this absorbed the color very rapidly, a broad and decorative treatment was necessary; but as both the enamel and colors fused at the same time, making one harmonious whole, very rich and vigorous effects were produced. Later the painting was applied on the fired enamel, and more minute details were possible, the ground itself furnished excellent high lights, which could be attained by simply scratching away the color and it was possible to trace the finest line and most minute details on its hard and polished surface. By the early method pieces of the greatest decorative beauty were produced with simple color effects in blue and a yellow metallic

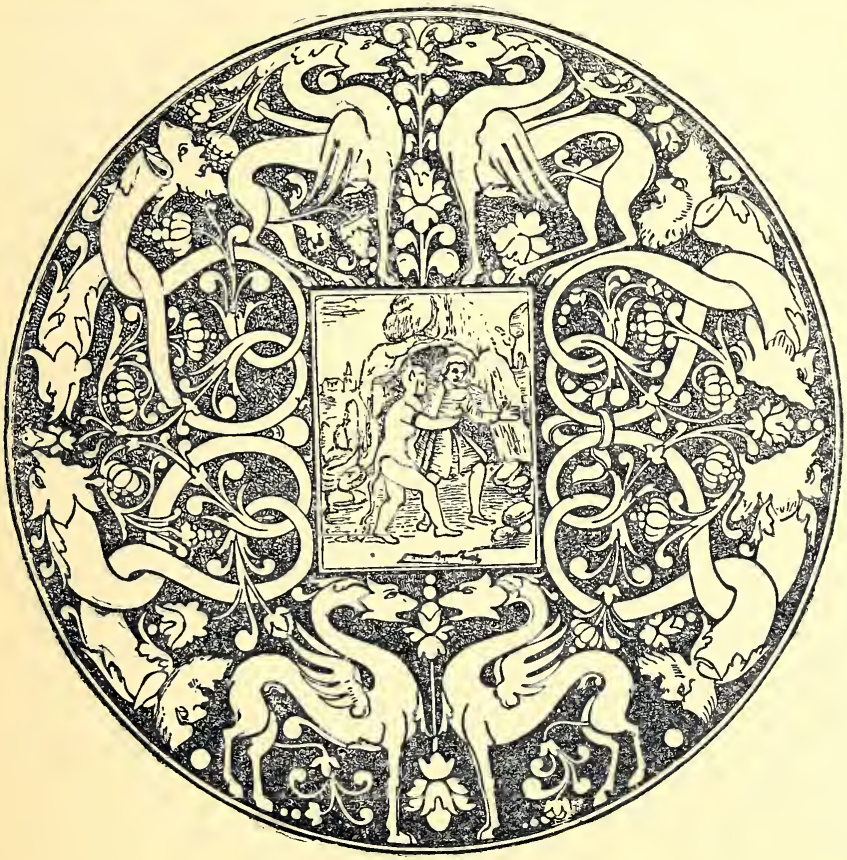
lustre: generally figure subjects, often surrounded with borders of medieval simplicity. The Gubbia majolicas have a deep ruby lustre which was largely used by Maestro Giorgio of Gubbio (A. D. 1517-37), who is further credited with the invention of gold and silver lustres. So excellent were these lustres that wares from other fabriques were sent there to be lustred and often bear Giorgio's mark in addition to that of the place of manufacture. How highly Giorgio's work was regarded is evidenced by his being created a "Maestro," 
a title prized even more than nobility. He was a sculptor too and some of his altar pieces give him a high rank amongst the modelers of his period equal to that which he occupies as a painter. The illustration is of a deep tazza in the South Kensington Museum. Castel Durante had a manufactory as early as 1284. In 1500 mezza majolica, graffito and tin glazed majolica were made. Plates and dishes with borders and centres of cupids were made about this time, and this style was later more fully developed. Vases and pharmacy jars decorated with trophies and grotesques, very soft in coloring, were also made. All old Italian palaces had a pharmacy attached to them and instead of glass jars used pottery ones. The ware was a pale buff color, the glaze rich and pure. The manufacture began to decline in 1631 .

Urbino is celebrated for the works of the Fontana family, "chiefs among Italian ceramic artists," Guido, Camillo and Orazio, the latter the most celebrated. His pieces are characterized by great softness of color, harmony and power of expression. A beautiful set of vases made for Duke Guidobaldo II., have for subjects the four Evangelists, the twelve Apostles, incidents in the Old Testament, naval battles of the Romans, and the metamorphoses of Ovid. On eighty-five of them are portrayed the games of children, every subject different: A Grand Duke of Florence offered for them a like number of silver vessels of equal weight, and Louis XVI. offered for the four Evangelists and St. Paul an equal number of gold statues. The Fontanas flourished during the first half of the sixteenth century, Orazio dying in 1571 . Their pieces were very seldom signed.

Another celebrated painter of the Urbino fabrique was Francesco Xanto, and his signed works date from 1530 to 1542 . They were frequently enriched with metallic lustres by Giorgio. Critics vary so much in their estimation of his work, which was principally adaptations from Raphael, and other artists, that I give one or two extracts.

"Xanto's execution, although dexterous, is monotonous and mechanical; his scale of coloring is crude and positive, full of violent oppositions ; the only merit, if merit it be, being that of a certain force and brightness of aspect; in every other respect his coloring is commonplace, not to say disagreeable even ; blue, crude opaque yellow, and orange-tints and bright verdigris-green are the dominant hues, and are scattered over the pieces in full unbroken masses, the yellow especially meeting the eye at the first glance."--Robinson.

"Among them are examples of high artistic excellence, although many of them betray want of care and hasty execution."-C. Drury E. Fortnum, F.S.A.

"Its highest glory came with Francesco Xanto, whose broad and generally true drawing and masterly composition mark him as one of the great artists of the Renaissance."-Miss Young.

"His work is very variable in excellence; his drawing is somewhat mechanical and coloring bright but inharmonious; a vivid black and green are seen; his subjects for istoriati are adapted from groups in the compositions of Raphael and other artists, but his subjects are original and show research."-Beckwith.

The production of pictured Majolica was carried on largely at Urbino up to 1630, and it appears to have been intended entirely for decorative purposes.

As late as 1773, a French artist named Rolet had a factory at Urbino, but beyond a single specimen at South Kensington, nothing seems to be known of him. 


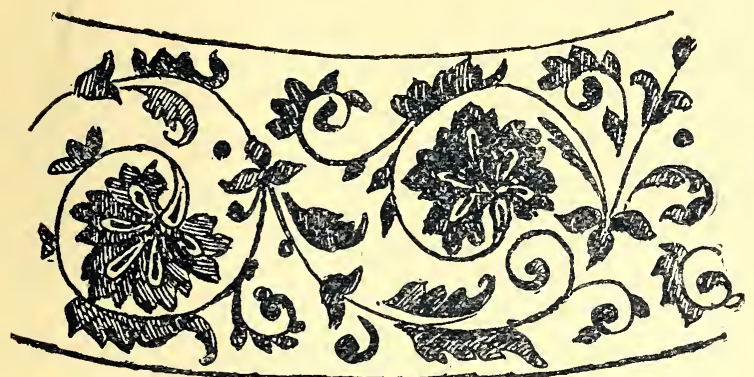

Faenza

Faenza was celebrated for the perfection of its designs, and, as early as 1485, mention is made of the distinguishing whiteness and polished glaze of its earthenware. Caffaggiolo, under the patronage of the Medici (Plate 4, fig. 37), Pesaro and near'y every city in Italy at some time produced Majolica, and many fine specimens exist in museums and private collections. (Plate 1, and plate 4, figs. 40,58).

Towards the end of the sixteenth century the manufacture began to decline, and, although continued during the seventeenth and eighteenth centuries, it is to France we must look for something of equal value to the Italian product of the sixteenth century.

About 1600 a follower of the Duke of Gonzaga, from Faenza, carried the Italian method to Nevers, in France. Brongniart gives the following as the composition of the Nevers body and enamel:

Body.-White limy clay............ $33 \mid$ Enamel.-Oxide of tin............. 20

Yellow plastic sandy clay. 50 " of lead............ 80

Gray, friable, less sandy $\quad$ Sand and some salt.....150 plastic clay. 16

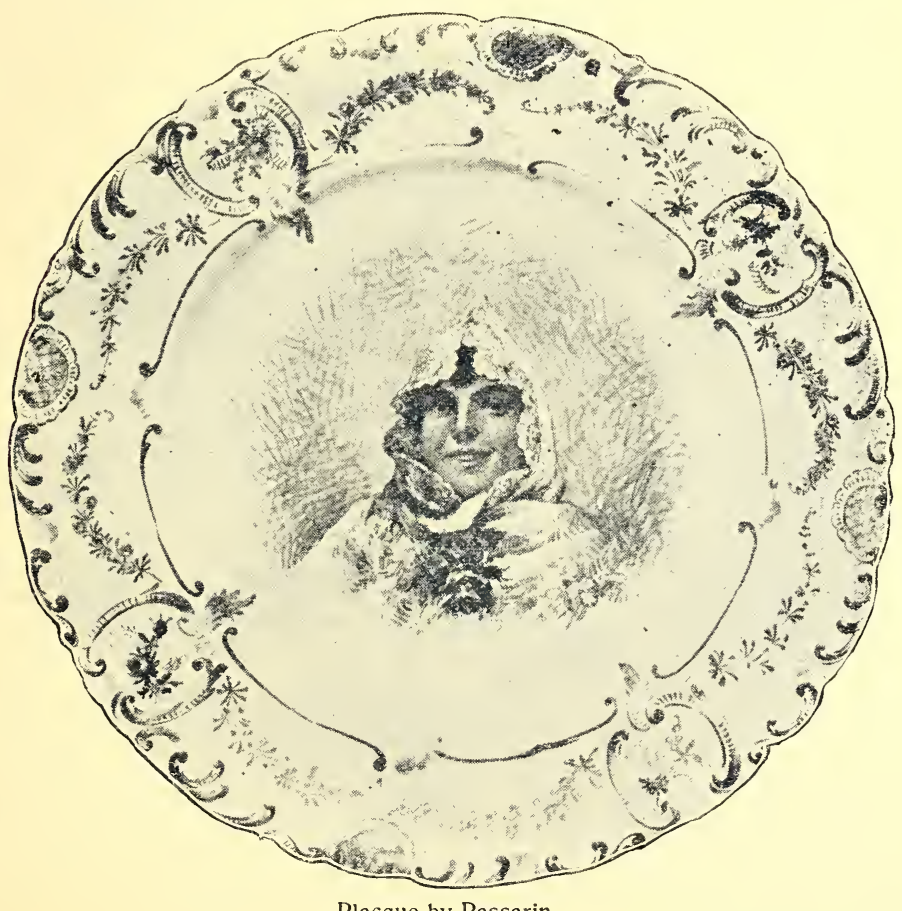

Placque by Passarin. 
These old Italian wares have been extensively reproduced within the last few years, the Marquis Ginori producing some excellent results. Salvini \& Co. and Jafet Torelli have been equally successful.

Raffaelle Passarin, of Bassano, does not confine himself to reproductions, but issues some excellent compositions of striking originality, executed in underglaze colors.

We give an illustration of a placque by this artist, through the courtesy of Messrs. Charles Ahrenfeldt \& Sons. Much of the detail has been lost, but it will serve to give an idea of the artist's conception.

\section{Ginori.}

The Marchese Carlo Ginori, established at Doccia, near Florence, a manufactory of china, and two years later sent out a ship to India for the purpose of obtaining samples of materials. He died in 1757, and the already well-established works were left to his son Senator Lorenzo, and the ownership has passed successively through various members of the same family until the present day. Successful imitations of all kinds of celebrated wares have always been a feature of this factory, from reproductions of Luca della Robbia to copies of Sèvres pâtetendre, and Meissen and Chinese hard porcelain, several specimens of the latter having been mistaken and sold for Oriental ware. Some of the moulds of the Capo di Monte iactory came into Ginori's hands, and he still issues reproductions from them. Lorenzo Beccheroni, an artist of ability, is intrusted with the work, and more nearly approaches the minute details characteristic of Capo di Monte than any of his competitors. (Plate 4, figs. 6 and 22).

\section{Capo di Monte and Buen Retiro.}

(Plate 1, fig. 8).

The Capo di Monte factory, situated near Naples, was founded in 1736 by Charles III., who also started the works at Buen Retiro, Madrid, after his accession to the Spanish throne. The soft china decorations at both factories wore numerous, the blue Oriental designs of Capo di Monte and the classical shapes of Buen Retiro being most esteemed. The former factory also produced Majolica. At Buen Retiro (plate 1, fig. 19), blue and white cameos in the Wedgwood style, were made, and the king had a room in the Escurial decorated with them. Some moulds of cups and saucers from the Capo d: Monte factory passed into the hands of the Marquis Ginori, who continues to produce them with the original mark. These have embossed and colored figures, the cups having coral handles.

\section{Medici.}

Tris was the first manufactory in Europe to produce porcelain, and was founded by Francesco, I, of the house of Medici. It existed only from about 1575 to 1587, anà was situated at Florence, under the directorship of Bernardo Buontaienti, who received great assistance from a Greek who had learned the secret of porcelain in 
China. Tbe decorations were mostly in cobalt blue, and to secure greater whiteness the body was covered with a white enamel, to which a rich pearly glaze was added. There are only about forty known specimens, consisting of plates, flasks, ewers, vases and pilgrim bottles. (Plate 1, fig. 9).

\section{Rhodian Ware.}

$66 \bigcirc 0$ called because it was manufactured by Oriental potters in the Island of $\circlearrowleft$ Rhodes, is made of rather coarse clay, covered with a fine white silicious slip, on which the decorations are painted, the whole being then covered with a thick glaze formed of silica, oxide of lead and soda. Its chief characteristic is the use of a fine red pigment which owes its color to the red oxide of iron. This pigment was applied in very thick body; so that it stands out in actual relief like drops of sealing wax. Plates, tall bottles, jars, mugs and pitchers with handles are the usual forms. They are all decorated with patterns of great beauty and splendor of color, brilliant blues, greens and the peculiar red being the chief. The designs are mostly flowers and sprays springing from one branch, often with black scrolls on blue and white. Geometrical patterns are also used but mostly for wall decoration. 'The finest specimens of Rhodian ware date from the 16 th and first half of the 17 th centuries. * * * * The town of Lindus where ruined kilns yet remain, was one of the chief places in Rhodes for the production of this kind of pottery." Enc. Brit.

Good reproductions oi Rhodian are made by Boch Freres of La Louviere.

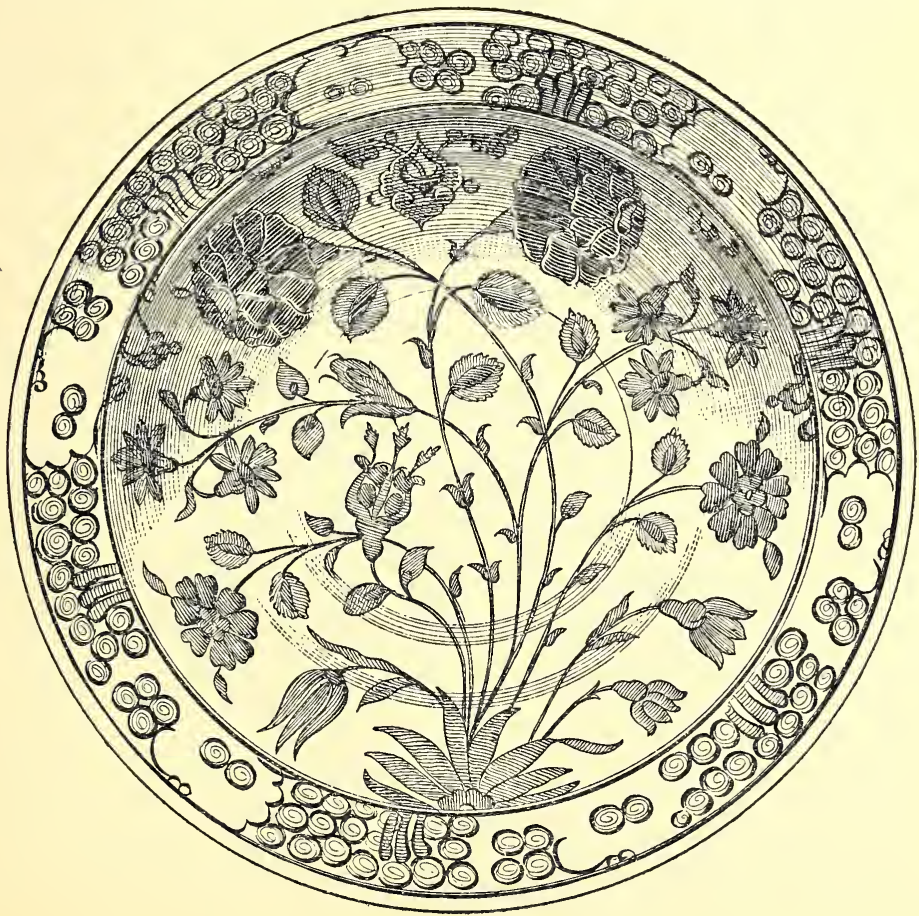




\section{Germany and Austria.}

Meissen and its School.

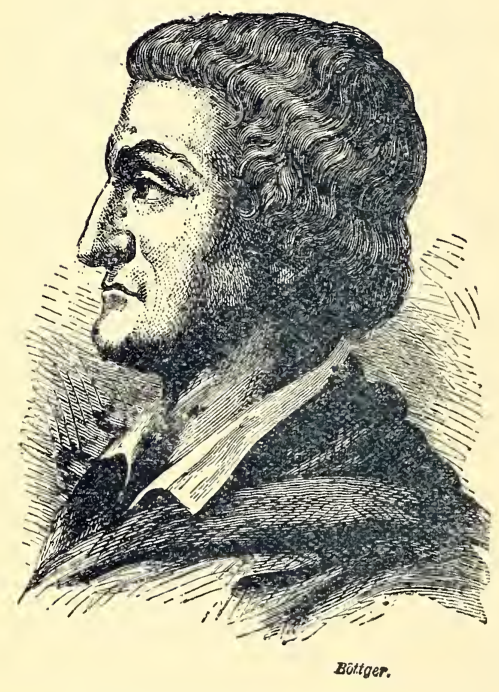

T was probably the Portuguese who introduced Chinese porcelain into Europe in the 13 th century, though in very sparing quantities and even as late as the 15th century it was comparatively rare. From that time numerous attempts were made to produce it in Europe, with the earliest results of which we have dealt elsewhere. But it was reserved to Böttger, a young chemist of great ability, to discover-accidentally it is true-the secret of the manufac. ture of natural or hard porcelain.

Joh. Friedr Böttger, or Böttcher, was born in 1681, or 1682, at Schleiz, in the territory of Reuss. His father was the master of the mint at Magdeberg, and Schleiz. He was apprenticed to an apothecary in Berlin, but became an enthusiast in the search for the philosopher's stone. Incurring the displeasure of the authorities he was obliged to flee from Berlin. He found protection and patrons at the court of Saxony, and received large sums to enable him to prosecute his studies in alchemy. Disappointment ensuing, as he did not of course, succeed in making gold, he was called upon to reveal his secret in writing, and handed in a manuscript, expressed with the air of one completely master of his subject. The King however, was dissatisfied with this production, of which he appreciated the worthlessness, and readily consented to a request of the Count of Tschirnhausen, who desired to avail himself of the skill which he believed Böttger to possess, for experimenting in clays, with a view to the manufacture of porcelain. From 1701 to 1709, he worked for his patron, at Dresden, always closely guarded and virtually a prisoner, producing stoneware of a superior quality to that hitherto produced. He also made a ware like red jasper, so hard that it could be cut by a lapidary's wheel. These pieces are marked (Plate 1, fig. 20). In 1710 a lucky circumstance, of which he was quick to take advantage, resulted in the discovery of a bed of true kaolin. One morning noticing the unusual weight of the powder with which his wig was dressed, he enquired of what it was made and finding it was a finely powdered clay, procured a supply of it, with which he experimented and found that he had discovered the materials for a true hard porcelain. The deposit of this clay was at Aue and it was dug up and packed in sealed bags and brought to the castle at Meissen, which Augustus II. caused to be tilized as a factory. Situated some five miles from Dresden and more like a prison 
than a factory with its high walls and portcullis, where oaths of secrecy were imposed on the workmen, it was the birthplace of the first hard porcelain made in Europe. For nine years Böttger endured this life, and though his success was rewarded by large presents, which he invariably squandered, the confinement probably shortened his life and he died March 13, 1719. In the year follow. ing, the secret was betrayed by a workman named Stöfzel, who fled to Vienna, where an imperial establishment was founded. Other workmen carried the secret to 'other places, and royal works were set up in Berlin in 1755; in Petersburg in 1744, and at Munich in 1748.

The early productions of Meissen were copies of Oriental china ; relief decorations of flowers and foliage, and a painted underglaze decoration in dark blue. Böttger was succeeded by Höroldt, under whose management the output of the factory was considerably increased, both in style and quanity. In 1725, paintings of flowers, \&c., in miniature gave place to Oriental designs, and soon after followed the well known Mayflower decorations, in which the pieces were closely studded with May blossoms, modeled in high relief, and then colored and gilded. This was under Brühls' administration. Statuettes by Kändler, candelabra with raised flower work and scrolls formed a conspicuous feature from 1731 to 1756. After 1774 more classical designs, purer in shape and outline were produced. The early Meissen, or as it is usually termed Dresden mark, was a snake twined round a staff, or in cases where the pieces were made for the King, or from his design, the royal monogram, A. R., interlaced. Since 1721 two crossed swords have been used

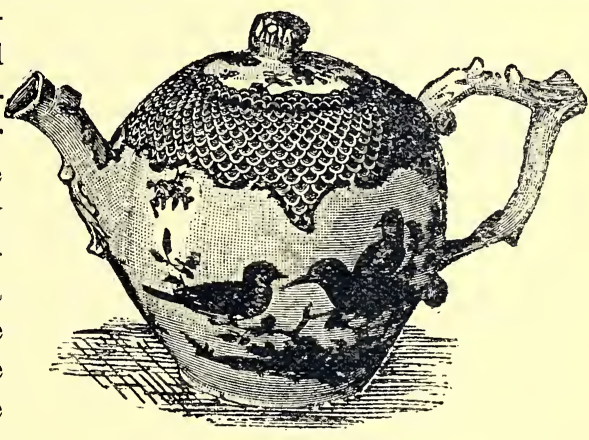
as a general mark, and the addition of a dot or star marks special periods. The letter B above the swords, or the letters M. P. M. indicate the period of Brühl's management. The crossed swords are the arms of the Elector of Saxony. (Plate 4, fig. 47).

The works are still in operation, many reproductions of old shapes and patterns being made, but no longer in the castle with its drawbridge and keep, more suitable premises having been erected in the Triebischthal, closer to the town, to which the factory was transferred in 1863. The present director is F. M. O. Raithel.

A Vienna workman named Ringler started a factory at HöcHs' 1 in 1740 (Plate 4, fig. 1). It was a state establishment from 1752 to 1774 and was under the directorship of Melchoir, a celebrated modeler. It is famous for its statuettes and cameo decorations in the style of Wedgwood. Some workmen stole the notes Ringler habitually carried with him and under the patronage of Charles, Duke of Brunswick, established a manufactory at Furstenburg (Plate 4, fig. 3). Some excellent figures were made here. Ringler joined forces with Paul Hannong, of Strasburg, at Frankenthal, about the year 1755, and it is here that the Carl Theodore china was made. In 1761 it became a government establishment and was eventually closed in 1800 (Plate 4, fig. 2). 


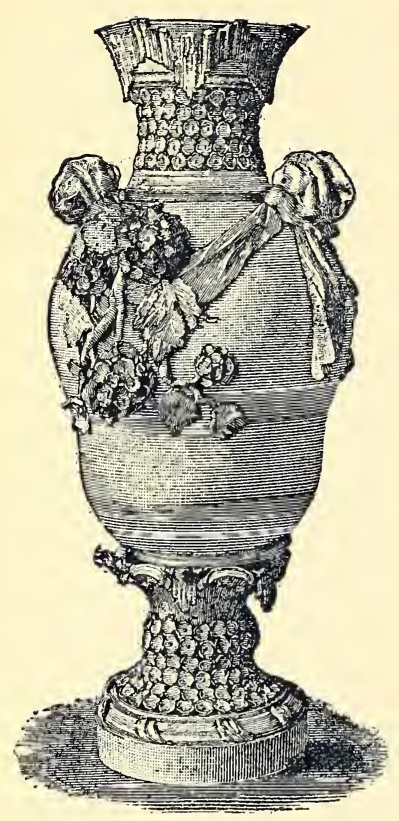

The Duke of Wurtemberg, in 1758 , founded a factory at Ludwigsburg (Plate 4 , figs. 4 and 5), and this Kronenburg china, as it is best known by, was of high quality, its characteristics being well-modeled figures and artistically executed paintings. This was in existence until 1821. Höchst workmen also started a factory at BADEN, which was in existence from 1753 to 1778 . These same workmen also sold the secret to a merchant named Wegley, who founded the factory at Berlin (Plate 1, fig. 17). It did not attain much prominence until Frederic the Great transported by force the workmen from Dresden and ordered the manufactory to be supplied with the Meissen clay. China second only to old Dresden continues to be produced here (Plate 4, fig. 9). Very large vases beautifully decorated, candelabra, busts, table services and pieces in pâte-sur-pâte are produced. The colors on Berlin china are especially rich and admirably contrasted.

\section{Germany and Austria.}

$\mathrm{T}^{\prime \prime}$

HE use of tin enamel and of enamel colors seem to have been known in Germany as early as the Thirteenth Century, but apparently fell into disuse and was superseded by the fine stone ware for which Germany has so long been celebrated. This is called by the French "Grès des Flandres," though for what reason is not apparent. The suggestion is hazarded that it may have been because they received it through the great emporium of Antwerp, the distributing point for the Rhine trade. In like manner Chinese porcelain was long designated as Indian, through our receiving it via the East Indies.

The name of the unfortunate Jacquelaine of Bavaria, whose cause was so warmly though unsuccessfully championed by the Duke of Gloucester, will always be associated with its manufacture, she having, during her long hours of captivity, employed herself in fashioning it.

The early examples have stamped reliefs, usually Gothic in character, or sharp incised patterns which seemed to lose none of their pristine freshness during the firing. Both lead and salt glazing were employed. Graffito ware was also made during the Seventeenth and Eighteenth Centuries. A coating of white slip was applied to a colored body, which was then cut away down to the body in the form of the ornament required.

The best qualities of stone ware were made at Cologne.

The history of the well-known house of

\section{VILLEROY \& BOCH}

furnishes us with much valuable information respecting pottery in Germany during the present century. It was established January 1st, 1841. Mr. Villeroy was pro- 
prietor of an earthenware manufactory at Wallerfangen, which was founded in 1789 by his ancestor, Nicholas Villeroy, who for a long time struggled against adverse fortune, and it was not until 1828, when Aug. Jaunez, a Frenchman, was appointed director, that it was placed on a paying basis. He introduced the English system of manufacture and considerably improved the quality of the ware.

Pierre Joseph Boch, the son of a foundry workman, had made an attempt in 1748 to manufacture pottery in Lorraine, but on account of an unsuccessful lawsuit was obliged to abandon it, and he and his two brothers went to Septfontaines and obtained a concession from the Austrian government in 1766 , to carry on an earthenware manufactory there with the further privilege of styling it the Imperial Royal Manufactory. Cream color was the staple product, but in 1790 they were producing small china ornaments and figures in pâte tendre (Plate 4, fig. 24). This probably only lasted until 1795. In this year, during the siege of Luxemburg by the French, the factory was destroyed, but was rebuilt about seven months later. P. J. Boch died in 1818.

His son, Jean Francois, had in 1809 bought the Abbey of Mettlach, suppressed by the French Republic, and obtained permission to establish a factory there, but only on condition that coal instead of wood should be used in the firing. To Mettlach therefore is to be ascribed the honor of first using coal for fuel in the firing of pottery on the Continent, as it was also the first to use the English process of print-

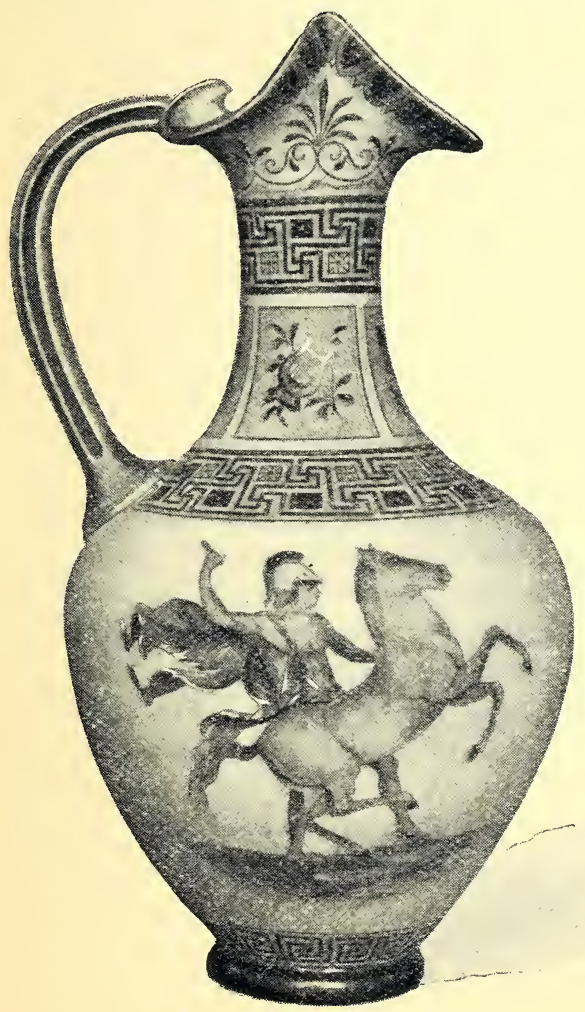

Rudolstadt Vase. Page 84 ing from copper plates. It was not until after the amalgamation of the firms that they commenced the manufacture of stone ware with inlaid designs in colors, for which they have to-day an unrivalled reputation. The old tower in the grounds of the Abbey was adopted as a trade-mark (Plate 2, fig. 44). J. F. Boch died in 1858 and was succeeded by his son Eugene. So large a variety of goods were produced, so many new manufactures were added that the premises became inadequate to their requirements, and the carthenware business was installed in a new factory at Dresden, of which Mr. Edmund Boch has charge, with De Welkens as director, a position he has worthily filled since 1874 .

A factory for Mosaic Tiles was also built at Mettlach, directed by René Boch, where immense quantities of tiles are produced, and so successful have they become that the term "Mettlacher Platten," has become the generic name for such productions in Germany. Mosaic and wall tiles are 
also produced very extensively. The firm have also factories at Wadgassen for glassware; at Merzig for mosaic pavements and at Schramberg for light earthenware and majolica. In these factories the firm employ over 5,000 workmen, and the consumption of materials is something like 135,000 tons per annum.

The drinking vessels and vases of Mettlach with those finely drawn and characteristic decorations, richly ornamented with inlaid colors, and the placques and vases in the style of the old Frankish ware, with bright blue painting predominating, are the best known products of the firm, and their merit has fairly earned the popularity they enjoy.

The general mark since 1874 is the head of Mercury, with the name of the firm and place of manufacture below (Plate 2, fig. 46), whilst for special art goods, fig. 47 is used, and for art goods made at Dresden, fig. 45. The mark, plate 4, fig. 25 , is the earliest Mettlach mark.

Other factories whose marks are given and whose goods find a ready sale in this country are briefly enumerated below.

Hutschenrenther, C. M., Hohenberg. The mark used by this house is the Austrian shield or bee-hive of the old Vienna factory. This is printed under the glaze on white ware principally on copies of Vienna shapes, and then sold to decorators, who use Viennese decorations and such pieces are often impudently offered as real Vienna china.

Gerbinge, F. \& A., Bodenbach. His specialty is re-production of old Greek and Egyptian pieces, very well done.

Herender China Factory, Herend (Plate 2, fig. 39). Established in 1839 and long celebrated for the wonderful reproduction of old Meissen, Sèvres, Chinese and Japanese. So carefully are these reproductions made in all their details, that, as an instance, Chinese ceramic artists are employed to decorate the Chinese pieces.

The New York and Rudolstadt Pottery was established in 1882. The products consist of finely conceived and executed ornamental goods, both in china and earthenware. Among their contributions to ceramic art, a large line of vases with richly colored grounds and figure subjects painted in panels commands special attention. These pieces are most beautifully and artistically executed by a large staff of painters, prominent among whom are Helbig, Müller, Carlo, Loufer, Wagler, Boch and Walter. It is most unusual for one manufactory to be able to find work for so many figure painters, but it is the less surprising that such an aggregation of talent should be gathered under one roof, when we see the beautiful results produced. The fine soft glaze is an important factor and greatly assists the artists in producing color effects. Another line of goods have solid grounds of brilliant enamels on which flower subjects, slightly conventionalized, are outlined in gold. The vase of which we give an illustration is one of a series of reproductions of Greek shapes, of which there is a large variety. Mr. E. Gutherz is the director. (Plate 3, figs. 42 and 43.)

Fischer \& Mieg, Pirkenhammer, near Carlsbad, were established in 1801. They make a good quality of china, large quantities of which are sold to decorators. (Plate 2, fig. 42).

$W$. Zsolnay, Funfkirchen. Established in 1855 , and produces a very fine quality of majolica, well modeled and richly glazed. He has lately bought up the factory of J. Fischer, Budapest, one of the most successful reproducers of old Dresden and 
Sèvres. The five church mark, (Plate 2, fig. 38) has such a deservedly good reputation, that we may feel sure the Fischer reproductions will not be issued under any other.

Mehlem, F. A. Bonn, A. R. Established in 1755. Royal Bonn has long been a favorite ware, and though some Bonn productions have been rather close copies of contemporary successes, there has been enough individuality about them to remove them from the suspicion of being foisted on the public as the genuine wares they resemble, each piece, in addition, bearing the factory mark. (Plate 2, fig. 20 and plate 3, fig. 40). Some very good pieces of Delft ware have been produced here, running the Delft factory very close for first honors. A recent production, giving a very charming effect, very restful to the eye, are large vases painted with landscapes in brown, with a very effective finish in gold and colored bronzes.

Meissener Ofen \& Porz, Meissen. Established in 1864 and producing principally useful articles. The well known Onion pattern, one of the original Meissen or Dresden successes is made here in large quantities and bears the mark plate 4 , fig. 23.

Ludwig Wessell, Popplesdorf, near Bonn. An old factory in existence since 1755 , and now employing about a thousand workmen. The products are styled "Imperial Bonn," and are of about the same character as those of F. A. Mehlem. (Plate 2, fig. 41).

$J$. von Schwarz, Nurembrug. A manufacturer of fine majolica, richly colored in bright warm tones. Some of his large pieces are extremely decorative and evidence great artistic feeling. Dr. Richard Lindhurst is the director. (Plate 2, fig. 43).

Dernheim, Koch \& Fischer, Gräfenroda, Thuringia, (plate 2, fig. 37), produce Bisque figures, raised flower decorations, \&c. The miniature furniture covered with Dresden flowers, in vogue a short time ago, was made here.

\section{Vienna.}

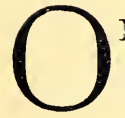

NE of the runaway workmen from Mcissen, named Stenzel, in conjunction with a Dutchman, Claude Innocent du Paquier, obtained a concession in 1718 for the purpose of producing china in Vienna. Whether Stenzel was incompetent and possessed only a rudimentary knowledge is uncertain, but no success was obtained and he returned without divulging his secret-if indeed he possessed one. Paquier continued the works and gave them a semblance of activity until 1744, when they were ceded to the government. Three years later Joseph Niedermayer was named master modeler and the manufacture of small figures was added. About this time the Austrian shield was adopted as a mark. The staff was considerably augmented; from the twenty employed in 1744, it reached two hundred in 1770, and three hundred and twenty in 1780. But the consequent increase in production had its effect on the quality of the goods, and a decline in style resulted. The factory was offered for sale in 1784 , but as no buyer appeared Baron von Sorgenthal was confirmed in his position as director. He introduced some judicious reforms, cultivated a closer study of art methods and soon raised the character of the products to a much higher level. Flaxman was employed and under 
his direction imitations of the fine potteries of Wedgwood were produced. Political events did much to injure the establishment until 1813 when it commenced by degrees to recover its lost prestige. In 1856, a decision of the Reichsrath suppressed it, and many of the models, \&c., were deposited in the Austrian museum. The mark was the Austrian shield. (Plate 1, figure 11).

Many German and Austrian manufacturers use this mark for Vienna shapes and designs up to the present time, but it is usually on the glaze, though even if under the glaze, that in itself is not sufficient guarantee that it is old Viennese.

Hutschenreuther, of Hohenberg, prints the mark under the glaze and mostly disposes of the white to decorators.

\section{Royal Danish.}

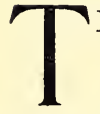

HE Royal Porcelain Manufactory, at Copenhagen, no longer "Royal" under its ownership, never had greater claims to its distinguished appelative, than under its present management. There is no pandering to public taste, if that taste, as is sometimes the case, is out of sympathy with that artistic feeling, which has always been such a dominating factor in the production of the factory. It is singular to what an extent the spirit of commercialism has been suppressed. There has never been any attempt made to produce a vast output

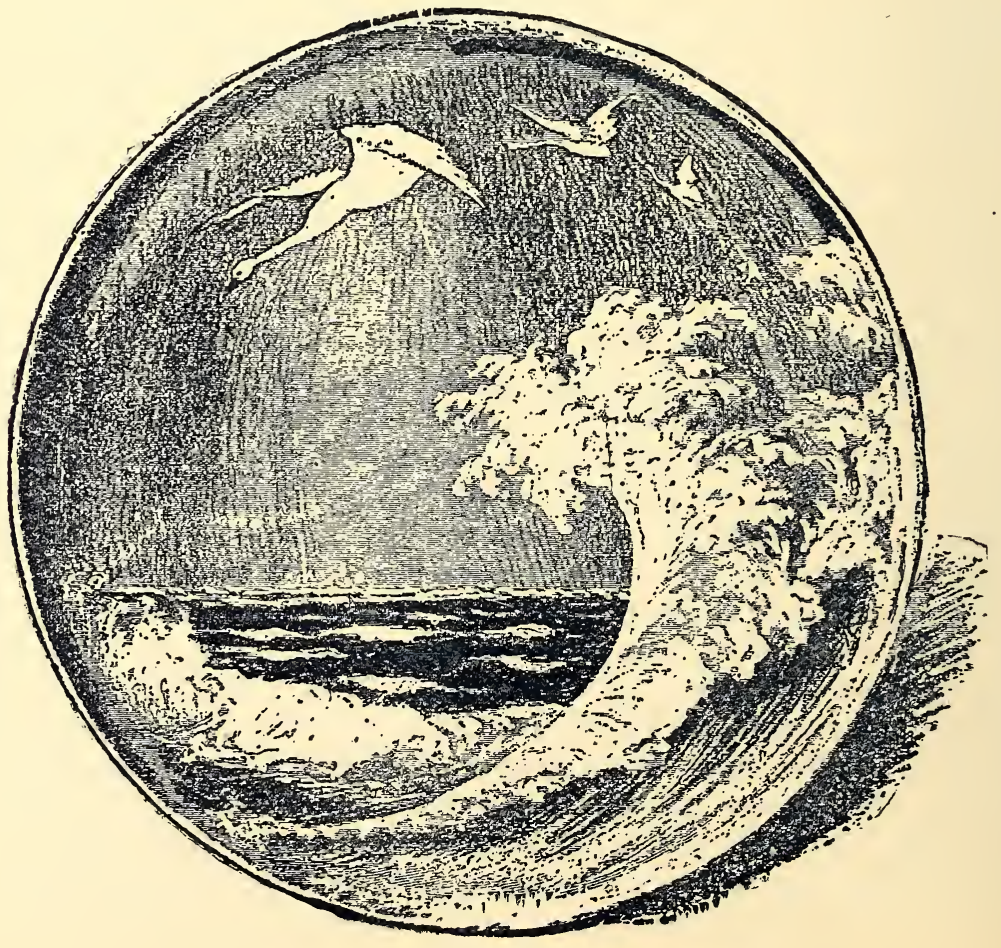


and this subordination of the commercial to the artistic motive is a characteristic of the factory, which in view of the-presumably-remunerative prices commanded for their productions affords food for serious reflection. A very early production of the Copenhagen works is the well known blue fluted pattern, entirely painted by hand in blue and simple in design, but notwithstanding the fact that a number of English and other potters have produced a similar pattern from copper plates, there is still a steady demand for the original "Royal Danish."

The Copenhagen factory was founded in 1772, by a chemist named Müller, and a workman from the Fürstenberg manufactory, but no great amount of success was obtained, and to rescue it from the difficulties that threatened it, King Christian VII. purchased it from the company incorporated by Müller. No notable success followed, with the exception of the production of a finely executed set, now in the royal castle at Rosenborg, decorated with specimens of the whole Danish flora and known as "Flora Danica" (and which in recent years has been reproduced), until their spirited reproduction in biscuit of many of the works of the celebrated Danish sculptor, Thorvaldsen, which from their excellent modeling and general artistic excellence at once placed the factory on a much higher plane than they had hitherto occupied. But the sales were not equal to the great cost of production, and in 1867 the manufactory was sold to Mr. Falck, who in 1882 resold it to the limited company "Aluminia," the owners of an extensive earthenware manufactory. The continuation of the use of the original trade-mark was authorized, extensive additions were made to the factory and it entered on a new lease of life. Mr. Philip Schou was intrusted with the administration, and he was fortunate enough to secure the services of Mr. V. Engelhardt, a chemist, and of Mr. Arnold Krog, an artist designated by Mr. Garnier, the Conservator of the Ceramic Museum of Sèvres, as of "undisputed talent and astonishing originality." Very decided advances were quickly made, and after the Copenhagen Exhibition of 1888, Mr. Schou was created a Knight Commander of the Legion of Honor. In the following year, again quoting M. Garnier, "All lovers of fine arts cherish the memory of these porcelains of such perfect manufacture, of a glaze so clear and soft, of forms so pure and delicate and of a decoration so simple and harmonious, whose distinction formed a glaring contrast to the overloading of the discordant pictures and glittering gilding of the neighbouring sections." And again in 1893, he says, "It was astonishing to see the results obtained by these able artists who, in spite of the technical difficulties and with only the three or four colors that can stand the temperature necessary for the firing, have succeeded in producing works of indisputable value, in which their individuality strongly asserts itself, works impregnated with a soft and tender melancholy, as the 'Lilies at Night,' by G. Heilmann, powerful as 'The Giant,' by Krog, or 'The Crows,' by Mortensen, of a marvellous skill in the execution as 'The Setting Sun,' the 'Flight of the Sparrows' and 'The Lilacs,' by Lisberg.",

These artistic productions so enthusiastically described by M. Garnier, were first shown at the Paris Exhibition of 1889, and aroused something akin to a sensation They are painted in "grand feu" colors, necessarily limited in number, but with so much originality and in some cases absolute daring have the Copenhagen artists treated their subjects, rivaling the best efforts of Japan, of which school there is a faint suggestion, that an entirely new school in ceramics was created, which for indi- 
viduality is only comparable with our own Rookwood. The Danish china is unequaled in its body, whilst the glaze is so clear and tender as to suggest the liquid depths of your sweetheart's eyes.

The trade-mark of the factory (Plate 2, fig. 22) is the three waved lines, representing the three Danish waters, the Sound and the two Belts. To meet Congressional requirements, the word "Danemark" underneath a crown is added, this latter a superfluity, as the productions require no insignia to attest their claim to be in fact as well as in name-_"Royal Danish."

\section{Delft.}

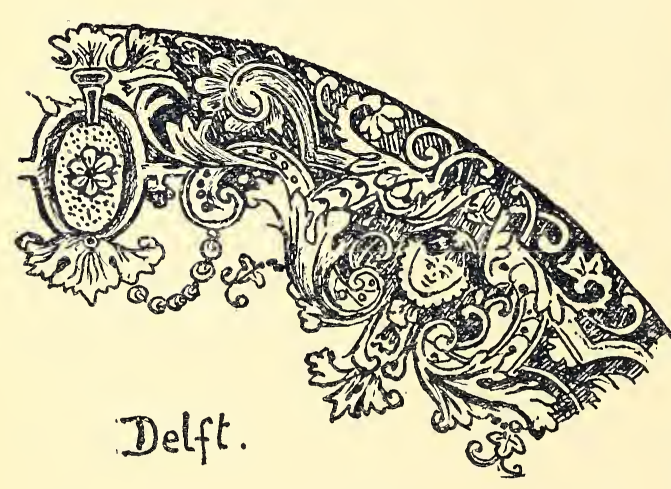

ABout the end of the 16 th century large quantities of pottery were made at Delft in Holland. To imitate Oriental ware the body was covered with an opaque white enamel, on which the decoration was applied. The best effects were in a deep rich blue and the ablest artists of the times were employed in their decoration. The ware was remarkable for its hardness and was very thin and light. Polychrome decorations were also applied, but these have generally little artistic value. A favorite pattern applied to plates was an arrangement of peacock's feathers. Hexagonal vases, beakers and copies of grotesque Japanese shapes were also made in large quantities. The marks, plate 1, figs. 2, are probably those of two members of the Kulick family. The manufacture began to decline towards the end of the 17th century, and many Dutch workmen settled in London and there originated the manufacture of what was first called "Delft ware." From London the manufacture drifted to Liverpool and Staffordshire, and in England the word Delft is frequently used in reference to almost any kind of pottery. *

The recent revival in this class of decoration is mainly due to Messrs. Thooft \& Labouchere, of Delft, who had a fine exhibit of it at the Chicago Exhibition. This house alone as far as I am aware is the only one that has adhered to the original methods of the old Dutch potters, their productions being in all details excellent reproductions of the originals (Plate 2, fig. 30). Anton Mehlem of the Royal Bonn factory also produces some very good pieces. Of their host of imitators, the bulk of the goods offered are beneath criticism, all that made Delft valuable being conspicuous by its absence. From this category exception must be made in favor of Messrs. Boch frères, La Louviere Belgium (Plate 4, fig. 38) who have issued some excellent pieces, and also to Villeroy \& Boch, which latter though produced by a mechanical process, are good both in drawing and color. Messrs. Boch's general mark is plate 3 , fig. 32 .

* She with her apron wiped the plates, and as she rubbed the delft."-Ingoldsby Legena. 


\section{Tournay.}

IN 1751 Peterinck, a native of Lille, obtained the privilege of manufacturing porcelain at Tournay. He engaged principally English workmen, and in 1759 the town council decided to send for an English Jesuit priest at the expense of the town, to convert them to the Roman Catholic religion. The bleu de roi produced here equaled that of Sèvres. (Plate 2, fig. 19). It is principally from this factory that the imitations of Sèvres emanate. The Paris workshops also produce them in abundance.

\section{Sweden.}

"THE LAND OF THE MIDNIGHT SUN."

RÖRSTRAND.

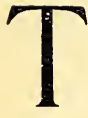

HE exhibitions of Philadelphia and Chicago first gave to the American public an opportunity of becoming acquainted with the Swedish potteries, through works as original and artistic as they were surprising.

The Rörstrand factory near Stockholm was established in 1727, under the patronage of Baron Pierre Adlerfelt. The first director, Jean Wolf, and his associate, Andre Nicholas Ferdinand, experienced great difficulties at the outset, but later, under the direction of Conrad Hunger, who had worked as a decorator at Meissen, the difficulties one by one disappeared and considerable progress was made and they enjoyed a monopoly in the manufacture of faience and were privileged to use the word Royal in connection with their title. In 1780, or soon afterwards, the three Crowns of Sweden were adopted as a trade-mark (Plate 2, fig. 33) their distinguishing badge having hitherto been an abbreviation of the name often followed by the date of manufacture (Plate 4, fig. 56).

The present high standing of the works is due in a great measure to the energy and pluck of the present director, Mr. Robert Almström, who, from a very humble position has, by dint of sheer hard work, unswerving incegrity and precision of judgment, raised himself not only to the position of director of the largest factory in Sweden, but has fitted himself for the duties of Senator and as worthily serves his country as he did his employers, in whatever capacity he was employed. Such gifts as his country could bestow have been willingly showered on him, and whether as a member of the City Council, of the Academy of Science or Director of the Bank of Sweden, he invariably commands respect. He has been decorated with the Cross of the Legion of Honor and with several Swedish orders.

At the time the management of the factory was placed in his hands about two hundred workmen were employed, where now, in the new buildings erected under his superintendence, over one thousand respond to the roll call.

The Rörstrand productions are so varied in character that it will only be possible to notice a few of them here. In pedestals and flower pots there is an almost 
bewildering profusion, both of shapes and decorations, characterized no less by the skilful modeling than by the harmonious color effects every where observable. Some of these pedestals are so airy and delicate in form as to make us wonder how they have retained their shape in the process of firing, but so excellent are the proportions that they impress you with no feeling of distrust as to their strength. Beautiful white creamy grounds, relieved in low tones of greens and browns mingled with gold are particularly attractive. Some have the embossments penciled in dark blue, whilst others are entirely covered with one tint of a rich, luscious glaze, amongst which a beautifnl plum color deserves special mention. It is astonishing that such rich and striking effects can be produced without sacrificing the quality of either body or glaze, both of which are evidently much harder and durable than is usual in this class of goods. These goods alone are sufficient to establish the Rörstrand factory in a very high position in the ceramic world.

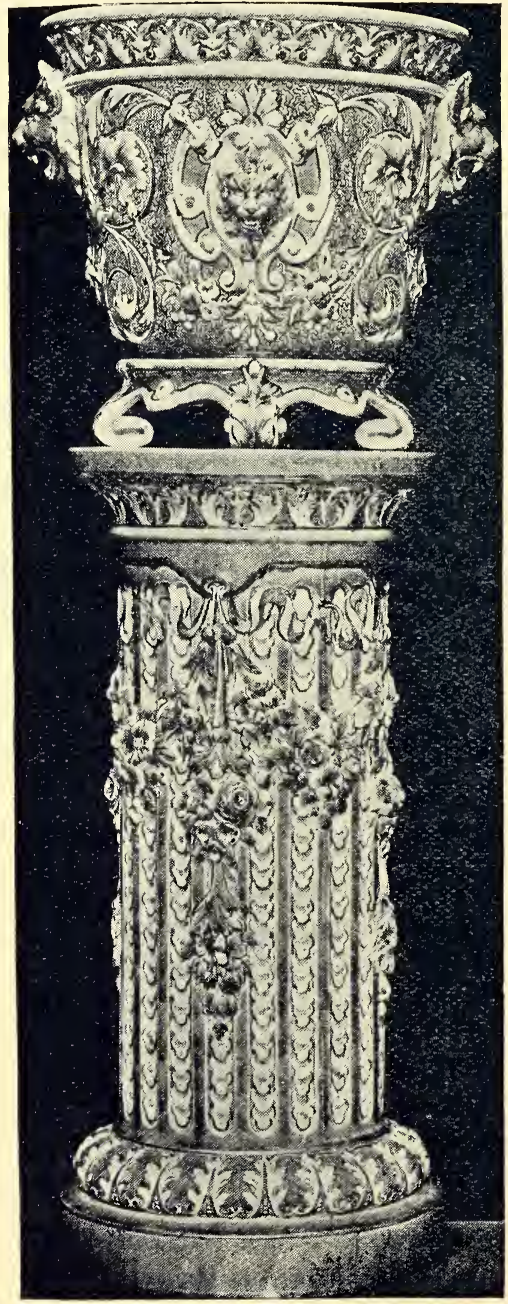

In vases, quaint of shape, there is a large variety, decorated with colored glazes. A bottle with a long narrow neck, in shades of blue varying from turquoise to mazarine, forms an object lesson of what these potters from "the land of the midnight sun" are capable of producing. It displays some color effects perfectly indescribable.

In china there is a large variety of plates, cups, chocolate jugs, etc., many of them very simple in design, others of a more ornate character. The body is thin and extremely translucent.

Beer jugs and mugs in stoneware with artistically executed incised designs, are an important Rörstrand production, and considering the short space of time they have been on the market, have acquired what must be a very gratifying popularity.

Some articles distinctly Swedish in character are the Walhalla drinking horns, which come in a variety of decorations, one of the most pleasing being an old ivory finish, relieved at the top with a colored border. These horns, suggestive of the mighty Odin and Thor, are supported by a gnome, a figure frequently introduced in connection with other ornamental forms.

Huge mugs with groups of Swedish peasants, illustrative of the work of Bellman, the Robert Burns of Sweden, and cigar ash receivers, illustrating Swedish 
costumes, have a quaint originality all their own.

Many patterns of dinner ware, both in china and earthenware, are produced of good design and finish.

Stralsund (Pomérania). A factory was founded here in 1731 by John Paskowitz, one of the best workmen of Rörstrand, and assumed some importance in 1767 under the direction of D'Ehrenreich. It produced at that time a number of important works, principally in blue.

Marieburg, in the environs of Stockholm, was the seat of a factory that attained some distinction. It was founded in 1758 , by Louis Ehrenreich, under the patron age of Charles Frederic Scheffer, one of the richest and most influential men of the Court of Sweden, who obtained for it the title of Royal Manufactory. The products resembled those of Neiderwiller and Strasburg, and were justly esteemed. Many of the decorations were flowers, leaves, etc., in relief. Some of the shapes, in striving after originality became bizarre, such for instance as a soup tureen in the shape of a bishop's mitre. In 1765 they adopted the English printing process. The works were finally closed in 1780 and the stock sold at auction (Plate 4, fig. 57).

Gustafsburg. There is a large factory here giving employment to about 1,000 workmen, and making a large variety of goods. It was founded in 1827 .

\section{China and Japan.}

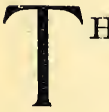

HERE seems no reason to doubt that pottery was made in China as early as 2697 B. C. The claim, however, as to the antiquity of hard porcelain is not borne out by the facts. The claim was based upon the discovery of some small vases in Egypt made of hard porcelain and inscribed with Chinese characters which were said to have been found in the tombs of Thebes, dating as early as 1800 B. C. But as these characters were found to be quotations from Chinese poets of the 8 th century, A.D., this fact was sufficient to demolish the theory. Hard porcelain was probably first made during the Han dynasty, $206 \mathrm{~B}$. C. to $25 \mathrm{~A}$. D. It is made of two substances pe-tun-tse and kaolin, the latter a white clay, derived from the decomposition of felspathic rock. Pe-tun-tse resembles it, but with the addition of a considerable proportion of free silica. The glaze is very hard and made almost wholly of pure felspar. This is the natural porcelain, the glaze and body being fired at the same time, the whole perfectly vitrified. Other natural porcelains are those of Japan, France, Dresden and Berlin.*

In Chinese porcelain, the earlier sorts were not decorated with paintings, but were all of one rich color. The period from A. D. 265 to 419 is remarkable for its

* Mr. F. W. Rudler says: "The felspar of granite decomposes; its alkaline silicate is removed and the silicate of aluminum, with which it was associated remains behind in a hydrated condition. It is this which constitutes kaolin or china clay. But if the decomposition of the granite is not complete, so that the felspar though altered still retains some of its alkaline silicate the product is known as pe-tun-tse, or china stone. Now since the alkaline silicate is a very fusible substance, it follows that the clina stone yields a more fusible product than the china clay. Hence the use of the stone or pe-tun-tse, in producing translucency, on in imparting to the porcelain more or less of a vitreous character. Curiously enough. it is said now that we have always been wrong in our use of the two Chinese terms, that in fact kaolin is used in China as a term for china stone and not for the clay: while the clay itself is called pe-tun-tse. We have in fact reversed their original use." 
blue : 518 to 618 for its green, and 954 for a deep sky blue, and from the fact that the ware was made extremely thin. Decorations do not appear to have been general until about the end of the 12th century, and were brought to great perfection under the Ming dynasty, 1368 to 1644 . The celebrated Chinese crackle ware is made by mixing steatite with the glaze, and the piece before firing is exposed to the sun, which cause the glaze to craze. Red pigment or black Chinese ink is then rubbed into the cracks to accentuate them, and the piece is then fired. Enamels of great brilliancy and depth are employed, blue, yellow, red and celadon. The yellow is made for the exclusive use of the Emperor. These peerless enamels are used both for solid grounds and painting. In their treatment of flowers the Chinese are particularly successful, but the decorations generally are feebly and poorly drawn and they seem to have no conception of the forms of birds, animals and the human figure. Nankin porcelain, painted in blue, with the hawthorn pattern, was exported largely to Europe during the last century and now brings high prices. It is probably not older than the 16th century and was made at King-te-tchin, the port of export giving it its name. The Aster pattern was another very popular decoration in blue, and when reproduced by Minton, in 1874, was an instantaneous success.

Amongst the curiosities of workmanship and evidences of the ingenuity of the Chinese, may be mentioned the "grains of rice" pattern, in which the design is cut in the body and filled in with glaze; the delicate egg shell china of the 15th century and the reticulated ware, consisting of an inner and outer shell, the outer cunningly perforated in intricate patterns.

The principal seat of the pottery industry was from A. D. 583 at King-te-tchin, and some idea of the extent of the manufacture may be gleaned from the fact that in 1717 three thousand kilns were in operation. The town was sacked during the Tae-ping revolution, and the factories destroyed. The town has since been rebuilt and the industry restored. There are other factories at Canton, Ningpo, Nankin and Pekin.

Grotesque and quaint shapes and decorations abound, but unmeaning as most of them appear, they have all a real significance. The familiar Kylin is an animal foretelling good. Its body is covered with scales and its branched head resembles that of the dragon, whilst its four delicate feet are terminated by clovon hoof resembling those of a stag. The Kylin is often confounded with the dog of Fo, which has its feet armed with claws; a grinning face with sharp teeth and a curly mane, its general aspect being like a lion. The $d o g$ of $F o$ is the habitual defender of the thresholds of temples and of Bhuddist altars. Dragons of all kinds and the weil known Sacred Horse frequently figure. The Fong-hoang, an immortal bird, only approaches men to herald happy events. It is recognized by its carunculated head, its neck surrounded with silky feathers and tail of pheasant and peacock. It was adopted by the emperors as their symbol, but later the dragon was substituted and the sacred bird became the emblem of the princesses. The imperial dragon is armed with five claws.

Brief mention must be made of the celebrated porcelain tower of Nankin, destroyed by the Tae-pings. It was built about 1403-1424 and was composed of porcelain bricks enameled on their exterior face. The surroundings of the openings were of porcelain, glazed with yellow and green, and ornamented in relief with figures of dragons. It was over 200 feet high. 
Chaffers gives an excellent summary of Chinese marks and peculiarities of decoration from which the following table is compiled:

Period or Manufacture. Date.

Acorus or acquatic plant, mark underneath,

Kiun,

A. D. $960-963$

Two fishes

66

"6.

Long-thsiouen,

969-1106

Thin iron nail, on enamel vase,

Iou-tcheon,

969-1106

Two lions and a ball, in centre of vase, . 1st quality Young-lo

1403-1425

Two mandarin ducks, centre of cups and bowls. $2 \mathrm{~d}$

Cups with handles ornamented with red fish,

Fighting Crickets

Hen and Chickens,

Fighting Cock

Grasshopper

Tea tree branch, centre of white cup

Bamboo leaves and blue flowers.

Seouven-te

66

Tching-hoa

66

66

For Emperor. Chi-tsoung

King-te-tchin
$66 \quad 6$

$1426-1436$

66 66

$1465-1487$

$66 \quad 66$

$66 \quad 66$

1522-1566

1567-1619

Japanese pottery and porcelain is of a much later date than Chinese. A writer in Chambers' Encyclopedia fixes it as early as 27 B. C., but this is undoubtedly incorrect. A rough kind of pottery was no doubt made, but it was not until about 1230 A.D., that a Japanese potter went to China to improve his process, and the introduction of glazed pottery in Japan was the result. Hard porcelain appears to have been first made in the Province of Hazen, in 1513. The Japanese is a born imitator, and one of the features of Japanese porcelain is its wonderful success in

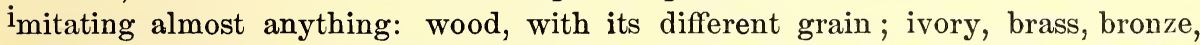
basket work-anything. Most of the early productions were copied from the Chinese, and the marks were also imitated, so as to make it difficult to distinguish them. Satsuma ware was originally introduced from Corea, and was made at first in a private factory belonging to the Prince of Satsuma. The most highly decorated kinds were not made until the end of the eighteenth century. The body is a fine ivory white clay, covered with minute crackled glaze, with minature paintings of birds and flowers in brilliant enamel colors. Only modern Satsuma has figure decorations. Most of the Satsuma now sold is a poor imitation, and is made in great quantities at Awata, Ota, Yokohama, Kiota and Tokio. Nearly all their elaborate and magnificent methods of ceramic decoration are of modern origin, as before the present century the simpler methods of the Chinese were used. During the last century large quantities of Japanese pottery were exported to Europe and frequently copied by the artists at Dresden, Worcester, Chelsea, etc.

Japanese Cloissonné brings high prices, though its artistic merit is doubtful, the writer of the article on pottery, in the Encyclopedia Britannica, characterizing it as "a marvel of technical skill and wasted ingenuity." The pieces of brass which form the pattern are set on edge, in what manner it is difficult to say, the compartments are filled with enamel, and the whole fired in the usual way.

As a decorator the Japanese is unexcelled, and he will arrange a few flowers or a bird in a charming way, which Europeans vainly strive to imitate. Many of the distinctive features of Japanese pottery are fast disappearing, owing to the absurd custom of sending over Western shapes and objects to be reproduced there. 


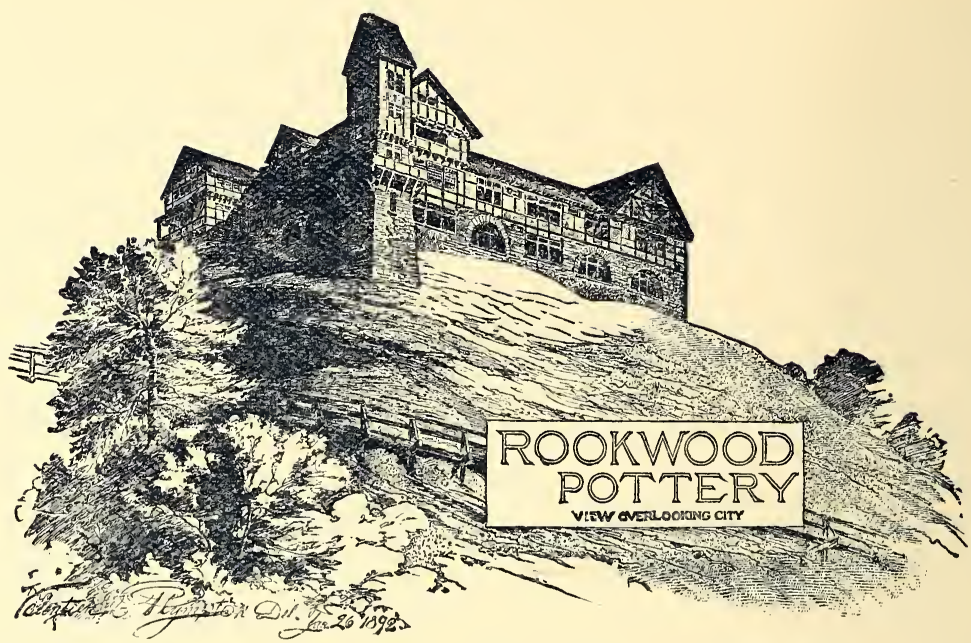

A

SINGLE piece of Rookwood pottery is an art education in itself. To take a piece in your hand and feel its velvet softness, to look lovingly on the happy blending of painting and glaze, is suggestive of a symphony-the music of some half-forgotten dream. With artistic evidence of feeling, the designs are suggested rather than displayed, and invariably they are in sympathy with the shape of the vase decorated. There are no bizarre effects; the greens, reds and browns are clear and rich in tone, aided sometimes by the color of the body itself, often by their own liquid depths; apparently unfathomable. It is difficult to restrain one's enthusiasm when writing of Rookwood. Only a poet could do it justice. It is moreover a distinctly American production, the result of American brains and energy, the capital for nearly a decade furnished by an American lady, Mrs. Bellamy Storer. Its clays are from the Ohio valley, its artists recruited entirely-with but one exception-from the Cincinnati Art School. Unlike artists in European potteries, who are not allowed to sign their work until public appreciation wrings permission from a reluctant employer, who has in view the glorification of his own name, rather than that of the artist who has contributed so much towards it-the Rookwood artists initial every piece of their work, and a list of these marks is gladly furnished, and equally they share Rookwook's success.

When Mrs. Storer founded the Rookwood pottery-it was under a less pretentious roof then-the Rookwood ware of to-day had no existence even in her imagination. Something was to ba created, something that, above all, should possess individuality, and be as much unlike existing pottery as possible. She and her assoviates were in full sympathy ; they had all the same aspirations, and the nobility of these were realized in the result. Founded in 1880, it was not until 1889 that the works became self-supporting. The intervening years were, for the most part, years of trial, of doubt and public apathy, but every kiln that was fired and drawn taught some useful lesson; taught more and more of the possibilities of applying a slip decoration to the wet clay body. In all these years Mrs. Storer was sustained by the unswerving faith of Mr. W. W. Taylor, her partner, an old and valued friend, and upon her marriage she turned over her entire interest in the pottery to him. Since 
1890 the Rookwood pottery has become a stock company of which Mr. Taylor in President, and Mr. Bellamy Storer, Vice-President. Success after success followed each other in rapid succession. Paris and Chicago accorded it all the honors they could ; the Royal Industrial Art Museum of Berlin, and the historic factory at Sèvres sent for specimens: Mr. Binns, of the Worcester Porcelain Works, spoke of it as "this most wonderful ceramic production," and envied America the possession of it ; and it has been eulogized by the press of the entire country.

The Rookwood pottery has never used any mechanical means in the produc. tion of designs, and, moreover, no two pieces are alike. Some few pieces are moulded, but the bulk is thrown on the potter's wheel to accentuate its individuality as much as possible.

Previous to 1886 the ware was usually stamped with the name in a variety of forms, but, in this year, the mark on cover was adopted. A flame at the top indicates 1887, and an additional flame marks each succeeding year.

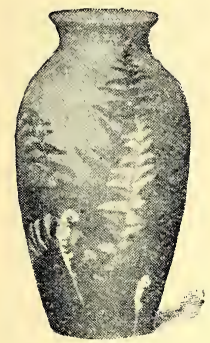

Amelia B. Sprague.

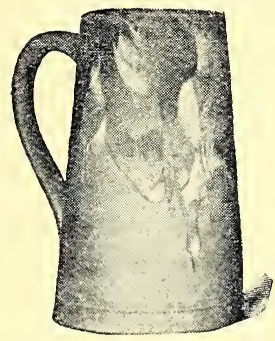

K. Shirayamadani.

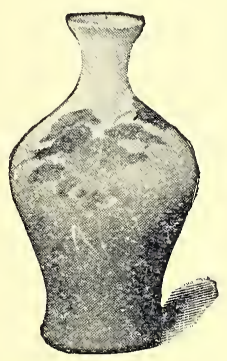

Constance A. Baker.

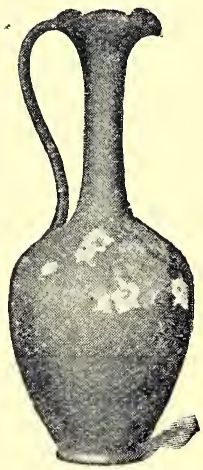

Geneva Reed.

Note.-I had originally intended to include in this work some notice of American pottery, but, during the last few years, the field lias so greatly widened, the advance has been so marked, that I found I could not do justice to the subject in the space at my command. I, therefore, arrived at the conclusion that I could best serve American interests, both commercial and artistic, by devoting a book entirely to "American Pottery," and, under that title, I have in preparation a work uniform in size with "Rough Notes on Pottery." This article on Rookwood is inserted here as an illustration of the interest connected with the subject. 


\section{The Process of Manufacture.}

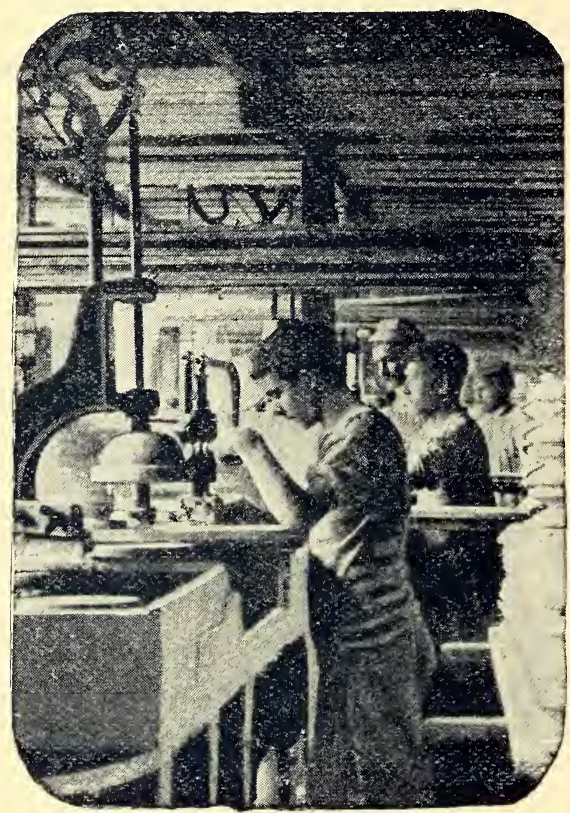

THE manufacture of pottery in its various processes is one of the most interesting and beautiful of all the industrial arts. It has been described over and over again, sometimes with a measure of appreciation, but more frequently with ludicrous mistakes as misleading as they are imaginative. The potter's wheel has a history equal to that of civilization; it has given us the best thoughts of the Greeks; it has inspired one of our noblest poets. It is alike a symbol of creative power, no less than of evolution. After an existence of thousands of years it seems likely to be relegated to desuetude by a horizontal revolving disc, eminently practicable, and known by the unpoetical name of the "jolly." Clay alone is by no means the sole ingredient of Pottery. Hard porcelain is the simplest form and contains but two substances, china clay and china stone. If you took a block of felspar and carved it into the semblance of a cup, the same as the Chinese do jade, you would only obtain the same result that the potter for a few cents supplies you with. Nature has decomposed the material; fire restores its lost properties.

Other varieties require a large number of ingredients. Some of the principal ones are china clay to give purity; ball clay to give plasticity and which is used as a base; flint to whiten and make porous; felspar to consolidate and close the pores like a glue, and bones or phosphate of lime to increase the translucency. It is apparent that the potter must have a thorough chemical knowledge of these ingredients. He must know exactly how one will act on the other so as to produce a perfectly homogeneous whole. The glaze must be in perfect agreement with the body, the firing must be carried up to but not beyond a certain point, or all his efforts are in vain, and the glaze will peel off at the edge or quickly craze. Crazed ware can be made apparently good by refiring, but the crazing is certain to re-appear. But knowing these things, he carefully weighs each material and puts them together in a circular tank called a blunger. In the centre is an upright shaft with a number of arms which are kept constantly in motion until the whole mass is, with the addition of water, reduced to the consistency of cream. It is then known as "slip." This mixture is run off into another tank called an agitator, where it is not allowed to settle. It is strained through a thick bolting cloth into another tank connected by a trough in which are placed a number of powerful magnets, so as to extract particles of iron that may have passed through the lawn. 
To separate the water from the clay the mixture is forced into a filter press, but it is still full of air-holes and must go to the pug mill. This is an upright cylinder, a little larger at the top than at the bottom, with an outlet at the lower part. In the centre of the cylinder is an upright revolving shaft to which knives are attached, which cut and mix the clay thoroughly and drive out the air-bubbles by being forced through a small aperture, and it is now ready for the potter. This last process was formerly done by men trampling the clay under foot, and is still practiced in France when an extra quality of body is required. The clay is now cut into pieces, weighed and passed to the thrower, who places it on his wheel, and under his skilful manipulation assumes the desired shape, the clay revolving rapidly, seemingly endowed with life and following the slightest change of his hands. Should the wheel have been superseded by the jolly, a thin bat of clay is placed in

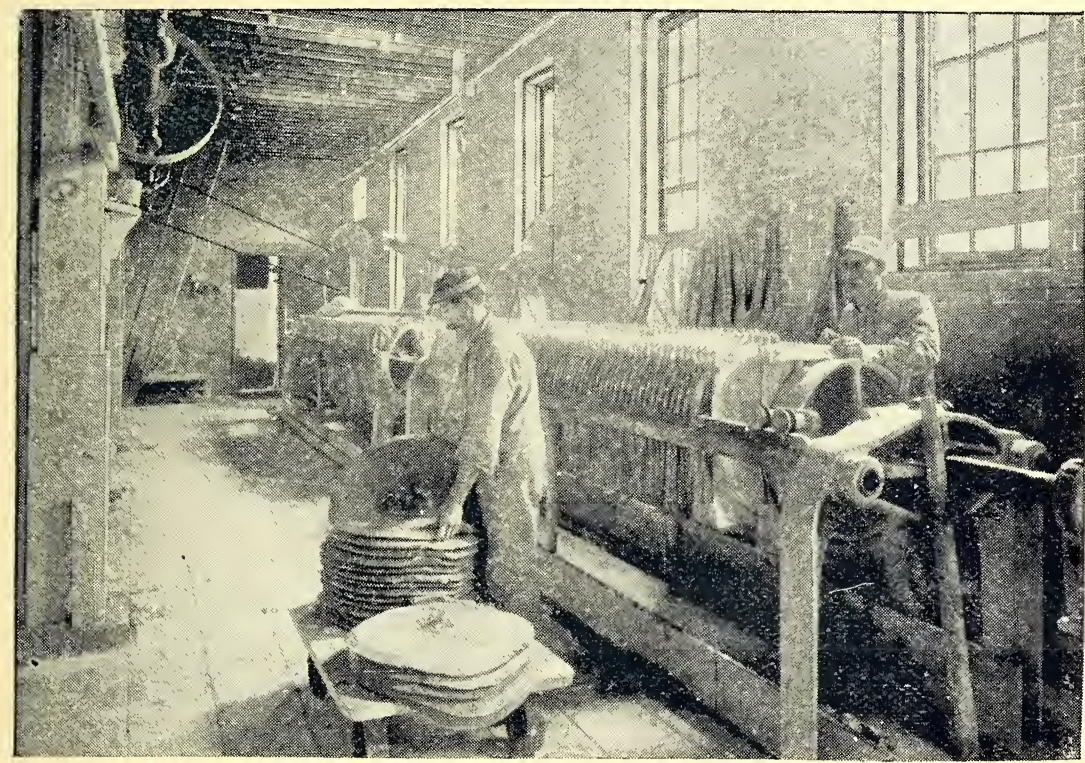

Clay Presses.

a mould which is put on the jolly, and whilst rapidly revolving the workman presses a tool of proper form, which is attached to an iron lever called a "pulldown," on it to shape the back of the plate or dish or the inside of the cup or bowl. The mould is taken away and placed to dry. Being made of plaster of Paris it absorbs the water in the clay, the article dries and shrinks proportionately and is easily removed. Cups, etc., are passed on to the turner who rounds the tops and smoothes them with a flat steel tool. Hollow pieces which, from their shape, can neither be thrown on an ordinary wheel nor jollied, such as cover dishes and tureens, are made by clay being pressed into a mould made in two or more sections and are called pressed goods. Each section of the mould is lined with a bat of clay, which is carefully smoothed with a sponge and a hard piece of rubber. The sections are then fitted together and held in position with a leather strap. A roll of clay is placed on the outside seams and the mould is put away to dry. Handles are moulded separately and fixed on by dipping the ends in slip. When the piece 
is taken from the mould the seams are rubbed down and it is put in the green-room for further drying until it is ready for the oven. Pottery ovens are built of red brick and lined with fire brick and are about sixteen feet inside diameter and sixteen feet to the roof or crown, above which the oven rises to a sufficient height to give draught to the fires. Around the base are the ten or twelve furnace openings which connect with the flues built under the floor and around the walls of the oven. The ware before being placed in the oven is arranged in saggars, a sort of box of irregular shape made of common clay. White sand is used in which to bed the pieces. When the saggar is filled a roll of clay is placed on its edge to exclude the dust and smoke, another saggar is placed on the top of it and the operation repeated until a tier or bung reaches the top of the oven. When the oven is filled with saggars the opening is bricked up and plastered with clay mortar. The firing then commences and

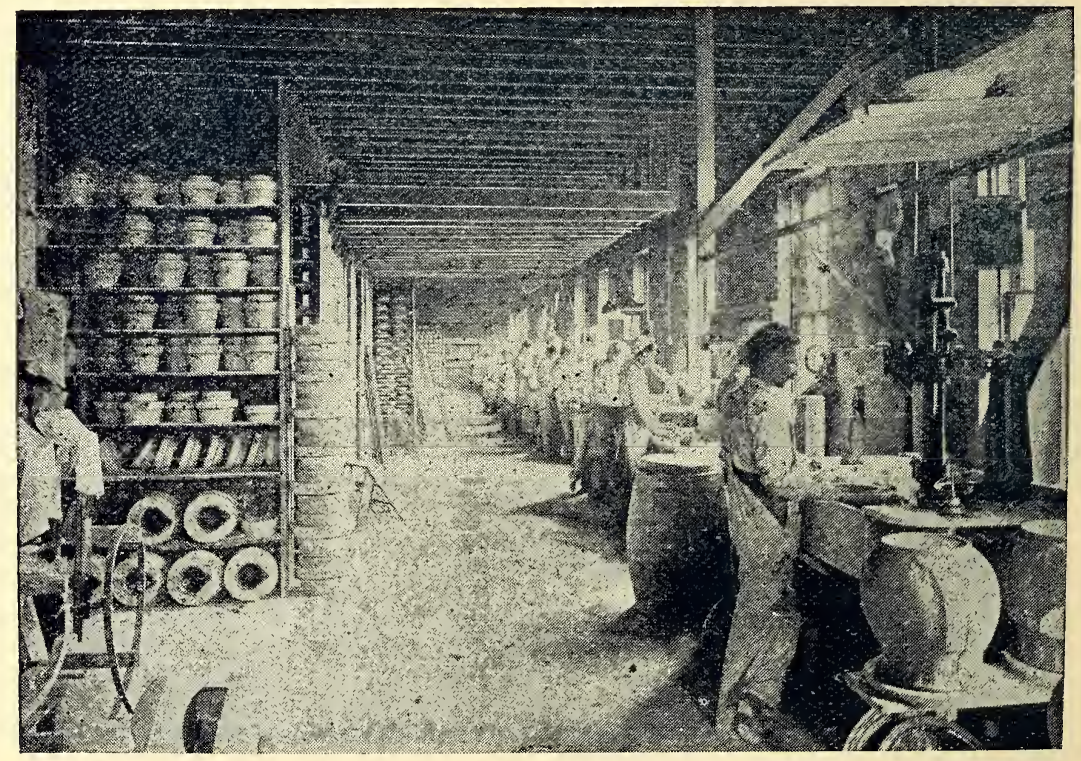

The Jolly.

lasts about forty-eight hours, and a heat of about $3000^{\circ}$ Fahrenheit is reached. The fires are allowed to die away and after cooling for about three days, the ware is taken out. This is called "drawing" the oven, and the ware has now passed from the "green" to the "biscuit" state. During the firing the ware has shrunk in size considerably. Parian shrinks the most, about one-third; ordinary earthenware about one-eighth to one-twelfth. This shrinkage increases the harder the ware is fired. Parian and other groups must have some of their parts propped in the oven to ensure them retaining their shape and these props must be made of the same body so that the shrinkage of the group and the props may be exactly proportionate.

Having reached the biscuit state the ware is now ready for decorating or glazing. In case it is to receive an underglaze decoration, it passes to the artist to paint on it whatever his fancy dictates or to the printer. For dinner, tea and toilet ware the copper-plate process is extensively used. The design is engraved on a 
copper-plate, which is charged with specially prepared color by the printer and an impression on tissue-paper is taken from it. This is handed to a cutter who clips

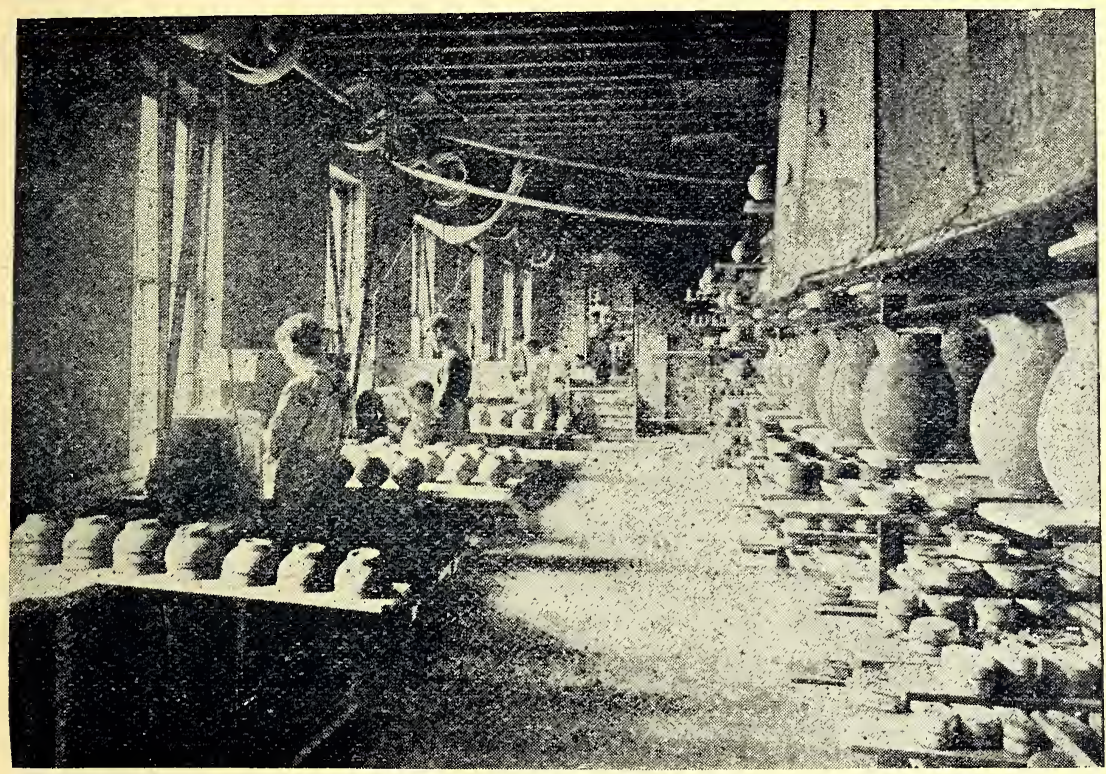

Turning.

away the superfluous paper and passes it on to the transferrer, who places it in the required position on the ware and rubs it with flannel until it adheres properly. The paper is soaked off by immersion in water and it is then sent to the "hardening-on" kiln, to remove the oil with which the color is mixed before it is ready for glazing. The dipper, standing by a tub filled with glaze, takes a piece in his hand, immerses it in the liquid and hands it to a boy who places it on a board. It is then

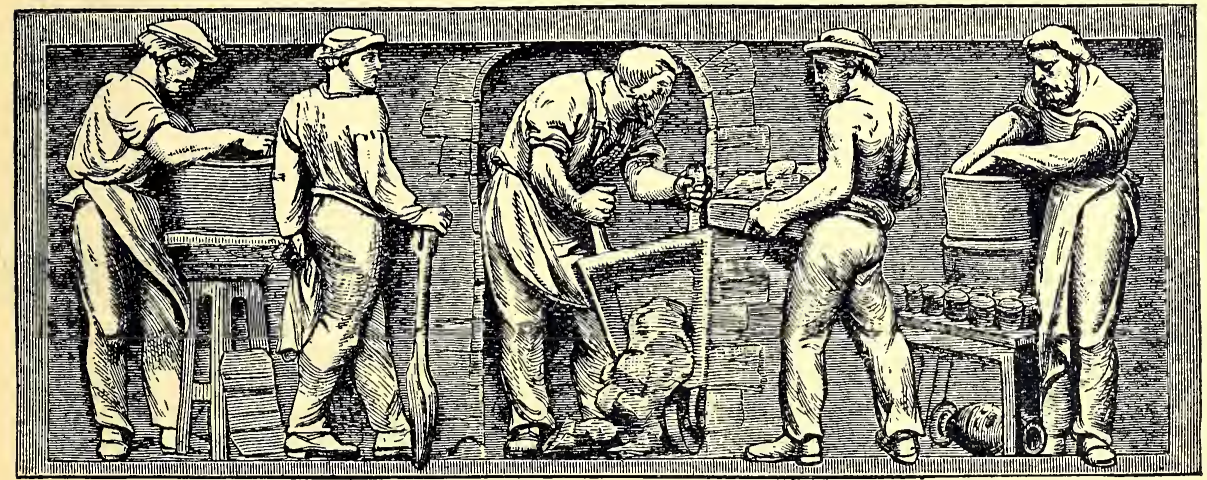

Firing. Bas-relief from Wedgwood Memorial Institute.

taken to the "glost" oven. Great care has to be taken in placing the ware for this firing, and small triangular pieces called stilts and spurs are used to prevent the pieces touching each other. This firing occupies about twenty-four hours. Should the ware require gilding it is taken to the.workshop and the gold applied and it is then fired for six or seven hours in an enamel kiln. These printed deco- 
rations can be applied either on or under the glaze. The former method prevails in England and the latter in this country. You have noticed in some dark blue patterns a beautifully soft effect caused by

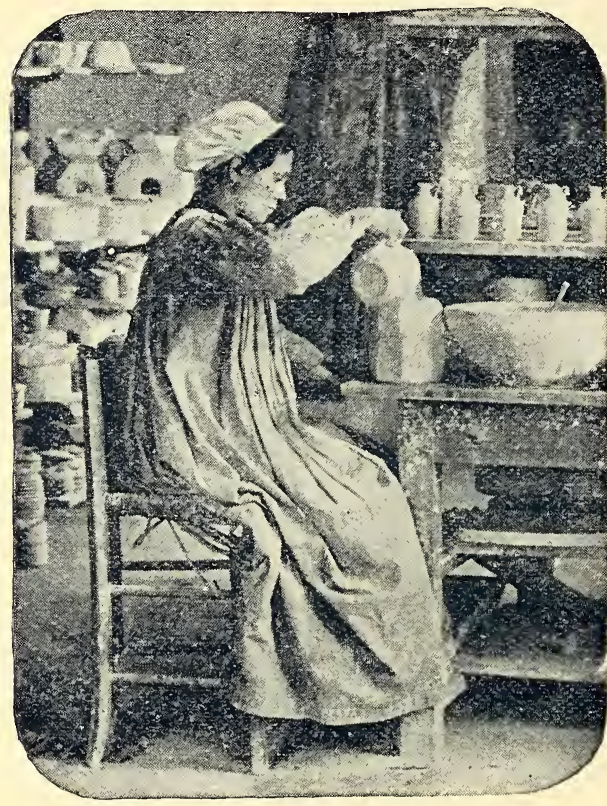

Casting.

Casting is described in the article on "Belleek." Most of the rich decorations on china, both French and English, are applied on the glaze, as many of the delicate colors fuse at a low heat and would be altogether destroyed if subjected to the heat of the glost oven.

The modeler, the mould maker and the engraver are all important personages in a fully equipped modern pottery, but their names are sufficiently suggestive without particularizing them more fully.

Just a word as to the sizes of some of the more staple pieces in earthenware. To facilitate the count, a workman is paid by the dozen, but this dozen varies from one piece to sixty. For instance, the bowl maker receives exactly the same price for making one very large bowl as he does for sixty small ones.

(For the illustrations of Filter-Press, the Jolly and Turning, 1 am indebted to the courtesy of The Potters' Co-operative Co., East Liverpool.) the flowing of the color. This is produced by placing in the oven a small quantity of "flow," consisting of salt petre, borax and lead, the heated fumes of which, rising in the oven, cause the blue to flow. Some pieces of this ware are stained with blue on the underneath, and it is popularly supposed that the color has gone through the plate. This is an error, the stain being caused by the color on the plate underneath "jumping" as it is termed.

In making hard porcelain the glaze requires the hardest fire. A French oven is divided in two stories. The bottom, and consequently the hottest chamber, is filled with glazed ware, whilst the superfluous heat passing into the upper chamber is all that is required to fire the green ware.

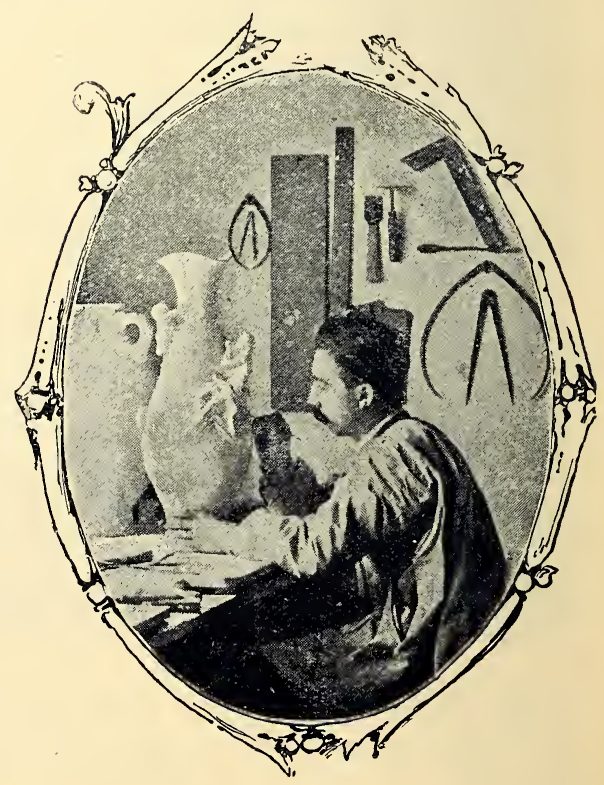




\section{Bests, Seconds and Thirds.}

$\mathrm{R}$

EGARDING the earthenware of Persia, it is of interest to remark that it formed one of the principal articles of export to India, in the 17 th century, when Chardin visited both of these countries. Chardin relates that the

Dutch traders were in the habit of sending Persian earthenwares to Europe, and there passing them off as Chinese. It would appear that the manufacture of earthenware was carried on in Persia on such a large scale in the 17 th century as to furnish a notable staple of the foreign commerce of the country; and also that a degree of excellence had by that time been attained, which enabled Persia to rival China in the markets of Europe. It would be a curious problem to trace through the Moors of Spain, and the potters of Delft, the unconscious influence of Persia on the ceramic art of modern Europe as developed in Dresden, Sèvres, and Staffordshire." From "Persian Art," by Major R. Murdoch Smith.

The Portland vase was found during the pontificate of Urban VIII (Barberini), between the years 1623 and 1644, by some laborers, who, while digging at a place called Monte del Grano, about three miles from Rome, on the road to Frascati, discovered a vault, which on being opened was found to be a sepulchral chamber, inclosing a sarcophagus of fine workmanship, and within this the vase in question, containing ashes. There was no inscription to give any light

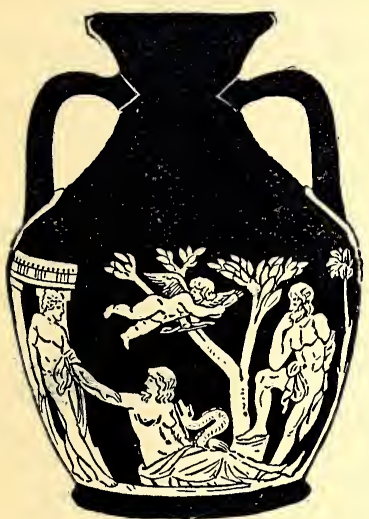
with respect to the person whose remains were deposited in the Sepulchre. The sarcophagus was placed in the museum of the Capitol, the vase was deposited in the library of the Barberini family, and continued for above a century to be one of the most admired pieces in that celebrated collection; it was generally distinguished by the name of the Barberini vase. After the dispersion of this library, the vase was purchased at Rome by Sir William Hamilton, by whom it was disposed of to the Duchess of Portland; at the sale of her Grace's valuable museum in 1786 the vase was purchased by the Duke of Portland for about 1,000 guineas.

Josiah Wedgwood borrowed the vase in 1786, from the Iuke of Portland, to copy. It took him four years to make a perfect copy, having to discover a body suitable and in close imitation of the original.

"The potters of Yezd once sent, as a challenge to the potters of Isaphan, a porcelain vase which held twelve pounds of water and only weighed one miscal. The potters of Isaphan sent to Yezd in return a vase of the same size and shape which only held one miscal of water and weighed twelve pounds." Persian Art.

$$
\text { * * * * }
$$

Holcroft the author of Road to Ruin, was a hawker of pottery.

There is more china clay used in the adulteration of fabrics, than in the manufacture of china. 


\section{List of Works of Reference on Pottery.}

Ancient Pottery. Birch. 1873.

Wedgwood and his works. Meteyard. 1873.

Life of Wedgwood. Jewett. 1865.

Ceramic Art of Great Britain. Jewett. 1877.

The Best and Most Complete Work on English Pottery.

Pottery and Porcelain. Marryatt. 1868.

Handbook of Marks and Monograms. Chaffers. 1874.

Palissy the Potter. Prof. Morley.

Josiah Wedgwood. Samuel Smiles. Harpers. 1895.

Two Biographies Everyone Interested in Pottery Should Read.

Ceramic Art of Japan. Audsley and Bowes. 1875-80.

Traité des Arts Ceramaiques. Brongniart. 1854.

Potting in Worcester. Binns. 1877.

French Pottery, (In the South Kensington Museum). Gasnault and Garnier. 1884.

The Ceramic Art. Miss Young. Harpers. 1879.

A General History of Pottery. Prehistoric, Oriental and Haviland faience the Leading Features.

China Collecting in America. Miss Earle. Scribners. 1892.

The China Hunter's Club. Harpers. 1879.

Both Very Interesting to American Collectors and Containing Much New Matter respecting English Pottery.

Pottery and Porcelain of all Times and Nations. W. C. Prime. Harpers.

\section{A Standard Text Book.}

The Art of the Old English Potter. M. Solon. Appleton.

Maiolica and Fayence. Beckwith.

Majolica. C. Drury E. Fortnum. F. S. A.

The Pottery and Porcelain of the United States. Dr. E. A. Barber.

Dictionary of Ceramics. Garnier. G. P. Putnam Sons, N. Y.

English Porcelain. A. H. Church, F. R. S. 1894.

"6 Earthenware "6 1894.

\section{A DEDICATION}

usually precedes the contents of a book,

but I prefer to place it here

as my last thoughts always are and always will be

of the generous assistance and kindly words of encouragement

so freely given by

Merrick Whitcomb, Esq., Pennsylvania University,

Messrs. F. P. Аввот and J. J. Miller, New York,

and my brother

Frederic Seely Jervis, Springfield, Mass.

to all of whom my heartiest thanks are due.

W. P. JERVIS. 


\section{MARKS AND MONOGRAMS.}

(Where the Trade Mark includes the Name of the Manufacturer it is not repeated here.)

Plate 2. 1, Gérard, Dufraisseix \& Cie. 2, 3, Delinieres \& Cie. 4, M. Redon. 5, W. Guerin \& Cie. 6, Haviland \& Co. 7, J. Pouyat. 13, Bishop \& Stonier. 14, Geo. Jones \& Sons. 15, E. J. Bodley. 17, E. Astbury. 19, Peterinck. 21, C. Krister. 22, Danish. 25, J. Maddock \& Sons (Hotel ware). 27, W. Adderley. 29, Brown-Westhead Moore \& Co. 30, J. Thooft \& Labouchere. 31, G. Grainger \& Co. 35, E. J. Ridgway. 36, Ridgway, Sparks \& Ridgway. 37, Darnheim, Koch \& Fischer. 40, Triebner Ens \& Eckert. 41, Ludwig Wessell. 42, Fischer \& Meig. 43, J. Von Schwarz. 44 to 47 , Villeroy \& Boch. 50, Tressemanes \& Vogt.

Plate 3. 1 and 3, J. Ridgway. 2, J. \& W. Ridgway. 4, Brown-Westhead Moore \& Co. 5, Worcester. 7, W. Ridgway. 8, Ridgway \& Abington. 9, Edge Malkin \& Co 11, Bates Walker \& Co. 18, J. Wedgwood \& Sons. 23, Faience d'Oiron. 24, Podmore Walker \& Co. 25, J. Beech. 30 and 31 , Belleek. 33 and 34, Utzchneider \& Cie. 35, H. Boulanger \& Cie. 36, A. Lanternier. 37-9, Keller \& Guerin. 40, F. A. Mehlem. 41, Cantagelli. 42-3, New York \& Rudolstadt Pottery Co.

Plate 4. 1, Hochat. 2, Frankenthal. 3 Furstenburg. 4, Kronenburg. 5. Ludwigsburg. 6, Ginori. 9, Berlin, (a) white; (b) decorated; (c) not sold in white; (d) 1850. 10, Coalport. 11, Stevenson. 12, Pennington. 13, Case, Mort \& Co. 14, Herculaneum. 15, Danish, 1772. 19, Minton. 21, Rouen. 24, Septonfontaines. 25, Mettlach. 26, Mennecy. 27, Bourg la Reine. 28, Sceaux. 29, Orleans. 30, La Courtille. 51, Niederwiller. 32-3, Clagnincourt. 34, Duc d'Angouleme. 35, Pont aux Choux. 36, St. Cloud. 37, Caffaggiolo. 38, Boch Freres. 39, Brameld. 40, Urbino. 41, Sincenny. 42-3, Lille. 44, Aprey. 46, Bordeaux. 47, Meissen. 48, Sceaux. 49, Savy. 50, Robert. 51, Perrin, 52, Niederwiller. 53, St. Amand. 54, Fouque (Moustiers). 55, Robertson. 56, Rorstrand 57, Stralsund. 58, Castel Durante.

\section{Tmporters Marks}

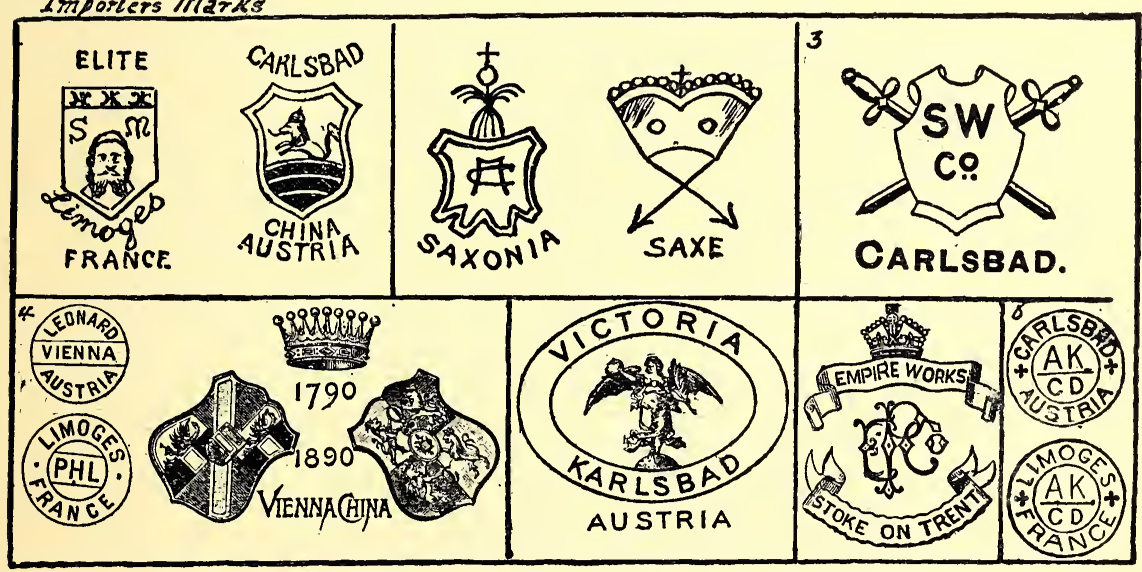

Importers Marks. 1, Bawo \& Dotter. 2, Chas. Ahrenfeldt \& Co. 3, The Strobel Wilkins Co. 4, P. H. Leonard. 5, Lazarus, Rosenfeld \& Lehman (Victoria and Fimpire Works). 6, C. L. Dwenger.

Marks on the Cover. 1, Sevres. 2, Gérard, Dufraisseix \& Co. 3, Brown-Westhead Moore \& Co. 4, John Maddock \& Sons, Ltd. 5, Rookwood. 6, Rorstrand. 7, Tressemanes \& Vogt. 
Plate 1

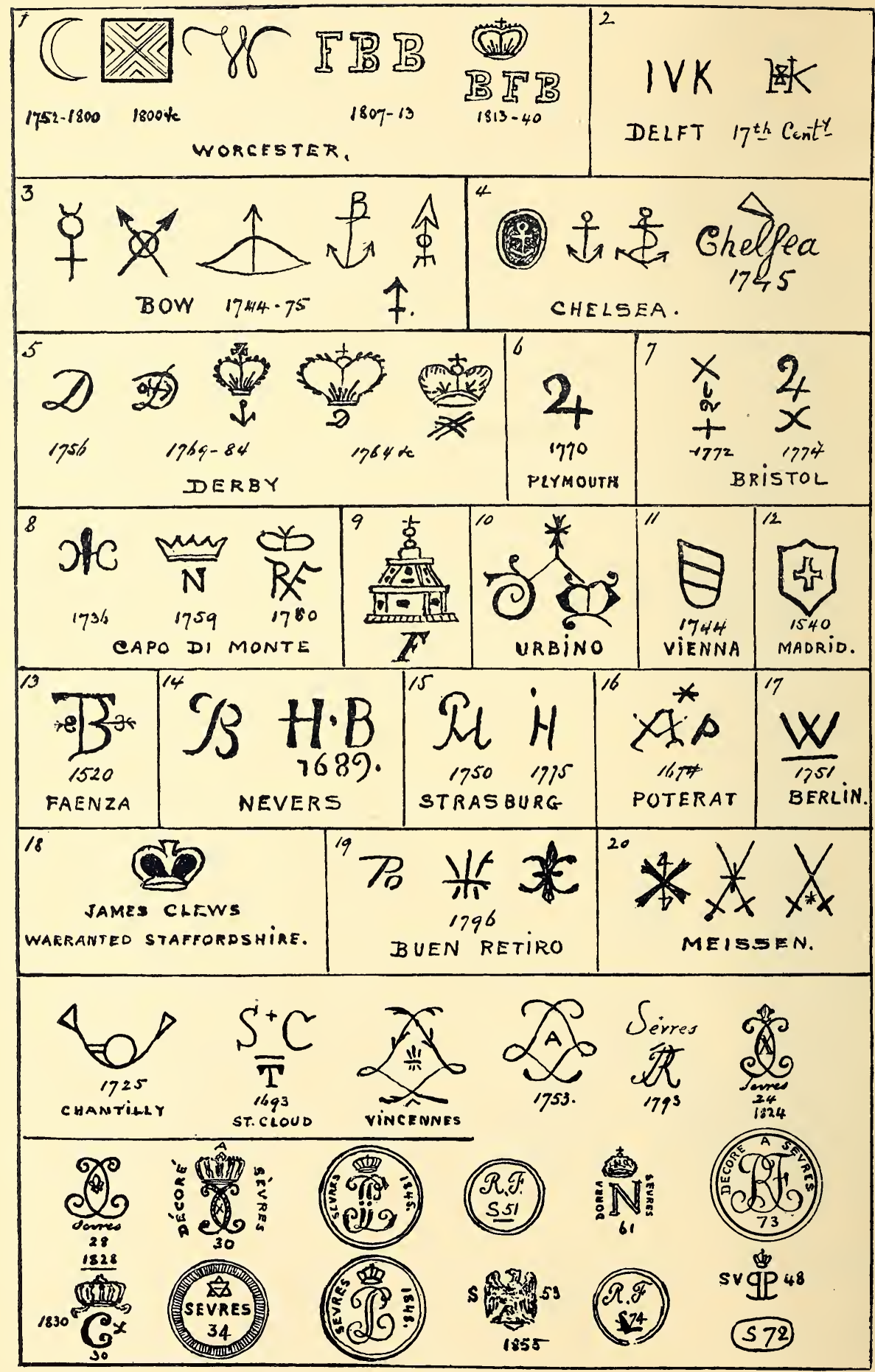


Plate 2

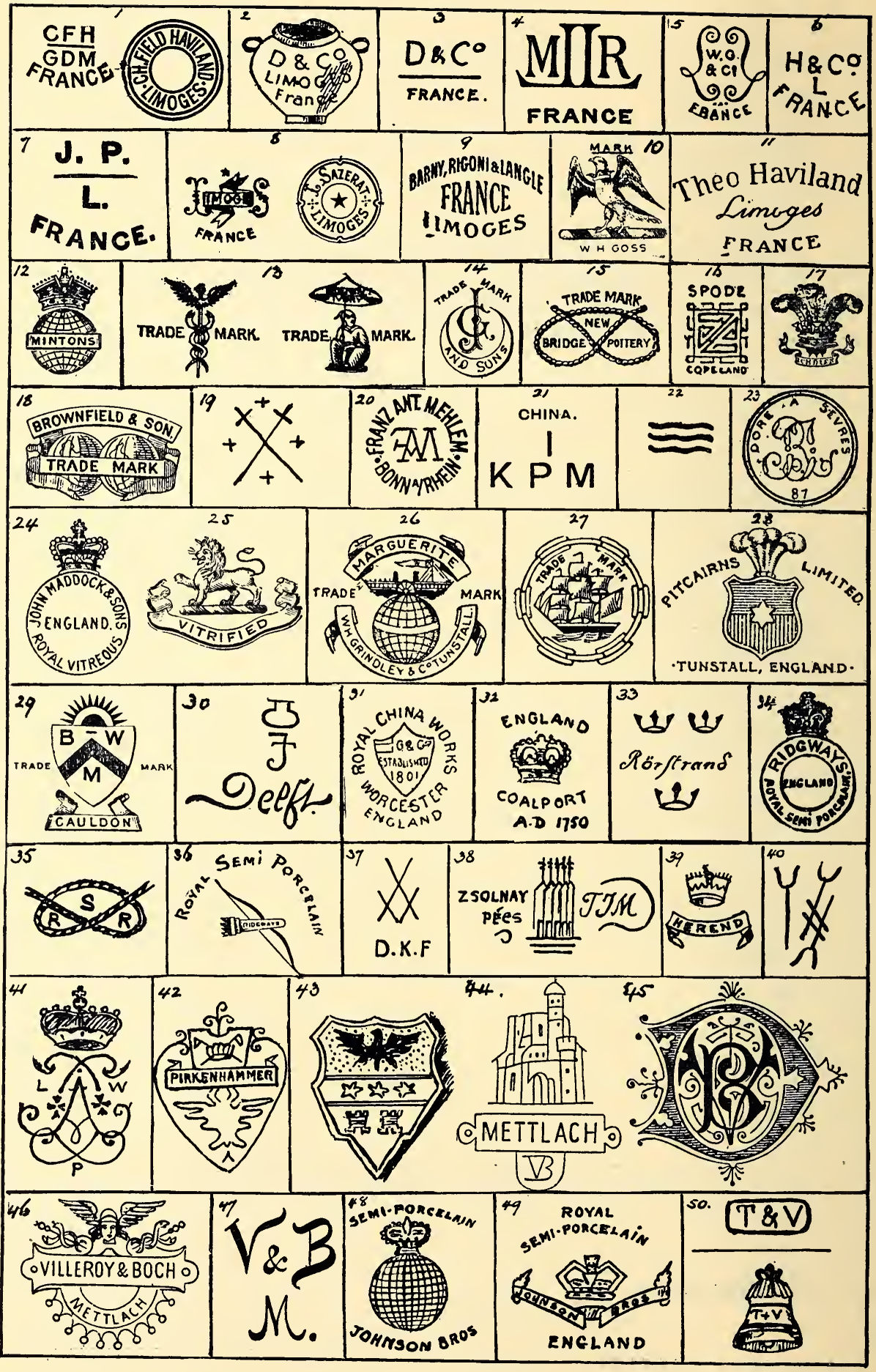



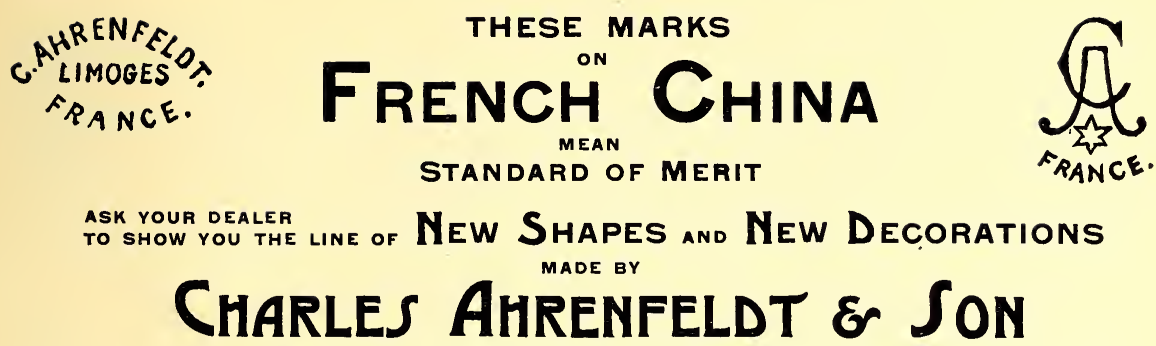

MANUFACTURERS AND IMPORTERS

50, 52 AND 54 MURRAY ST., NEW YORK

\section{Views of Old Boston \\ Souvenir China}

Jones, McDuffee \& Stratton Co.

have acquired the etchings by Blaney, engraved for Josiah Wedgwood \& Snns, Etruria, many of the historical buildings of Boston (and elsewhere), most of which have been copyrighted, and printed in old blue (under glaze). Among the scenes are Faneuil Hall, the State House Bulfinch Front, the Old South Church, the Old North Church from which Paul Revere hung out the lanterns in 1775; The Lamb Tavern, 1845, present site of The Adams House; The Old Federal Street Theatre, The Adams Lean-to House, Quincy, Mass., in each of which a president of the U. S. was born; Boston in 1768, Mt. Vernon, Longfellow's Home and others. Price, 50 cents each.

Visitors will find an extensive exhibit of the best products of the English, French, German, Chinese. Japanese and American Potterie and Glass Houses, in the Dinner Set Department, the Glasswork Department and the Art Pottery sooms. The stock occupies seven floors and ten thousand bins.

Jones, McDuffee \& Stratton Co., Pottery and Glass Merchants, WHOLESALE AND RETAIL120 Franklin Street, Boston, Mass.

\section{Swedish and Norwegian Pottery, Glass, Metal and Art Ware
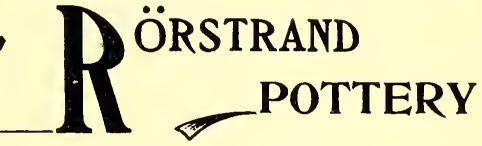

Agency for United States, Canada and West Indies

\section{Mikael Samuel E Co.}

\section{Park Place, New York}

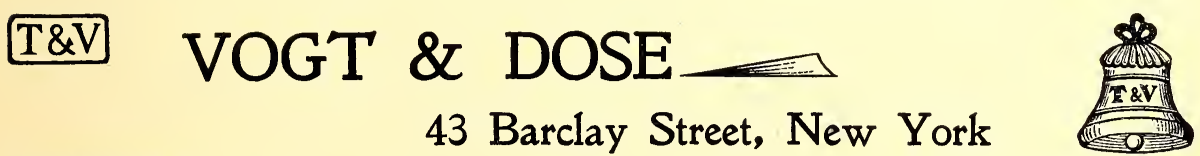

SOLE AGENTS OF

TRESSEMANES \& VOGT

LIMOGES, FRANCE

Decorated and White
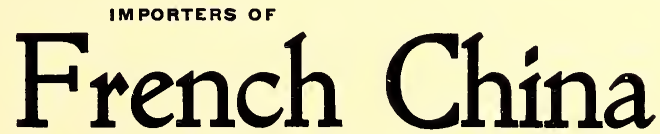

We carry the largest assortment in New York of French White China for Amateur Decorators, including novelties from all the principal manufactories. 


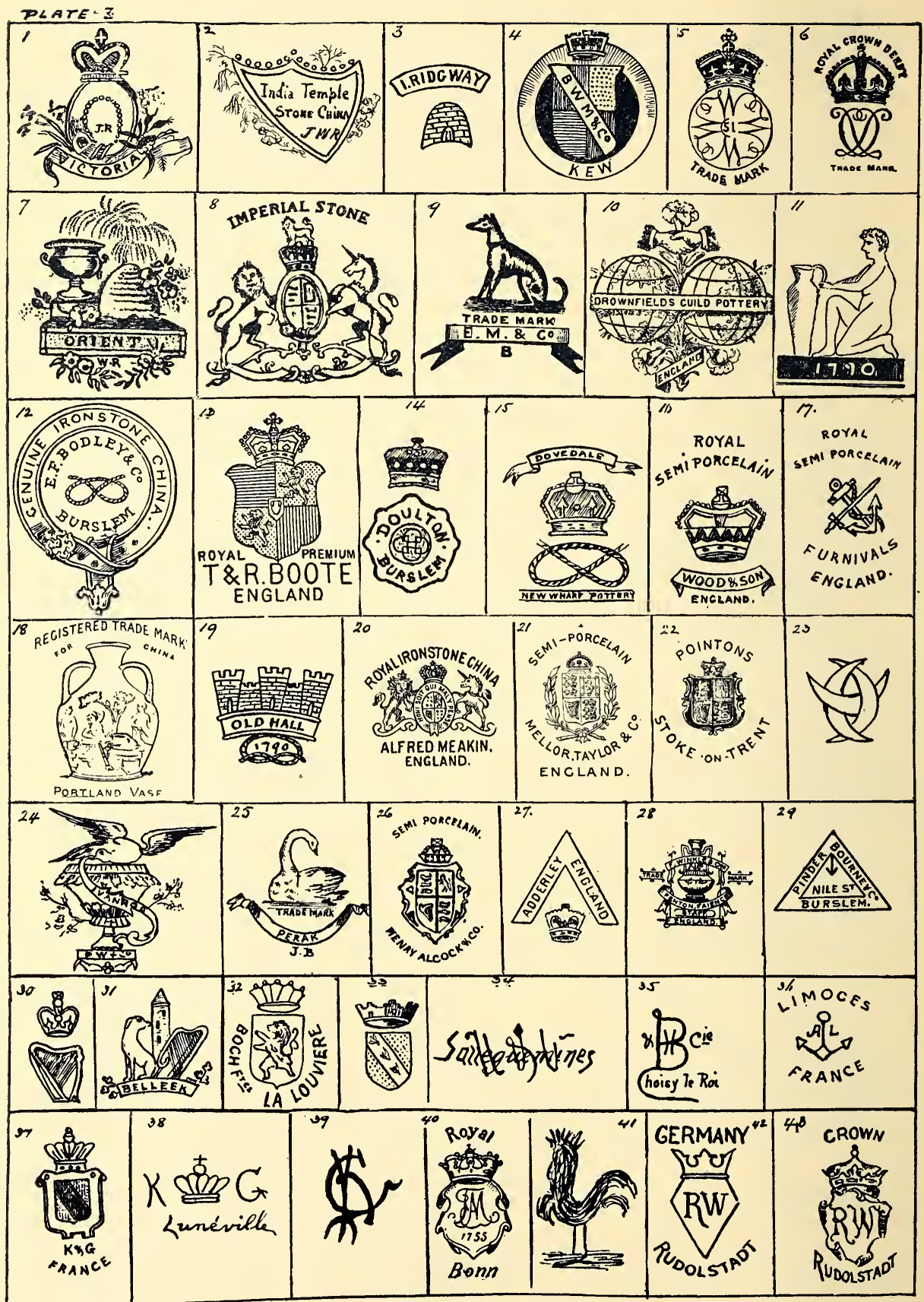




\section{ARTHUR TRUE}

39 East Twenty-Eighth Street

NEW YORK
EXHIBITION AND

PRIVATE SALE OF ANTIQUES

The Largest Collection

in the Country of

\section{American Historical Blue Plates}

For Sale at Reasonable Prices

Correspondence Invited

OLD FURNITURE, OLD PRINTS, PAINTINGS, and CURIOS

* MERCANTILE *

Photograph \& Engraving Co.

Chas. W. Smith, Proprietor

17 Park Place, New York

Photo-Engraving in Line and Half-Tone
Read

$$
\begin{aligned}
& \text { JOHN MADDOCK } \\
& \& \text { SONS, Ltd. }
\end{aligned}
$$

On Page 1 and $2 *$ NOTICE
To Jewelers

China Dealers, Etc.

\section{ARTISTIC POTTERY} REQUIRES

\section{Artistic Advertising}

Specially prepared copyright designs on single and double cards, beautifully executed, with space for your business address, now readyonly one customer in a town supplied. Send for sample. The cost is very Iittle more than an ordinary business card.

62 James Street

W. P. JERVIS

NEWARK, N. J.

\section{Chas. L. Dwenger}

* IMPORTER *

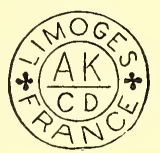

35 and 37 PARK PLACE NEW YORK

\section{“A. K." French China}

White and Decorated
"Love

me

Love

my

DOG"

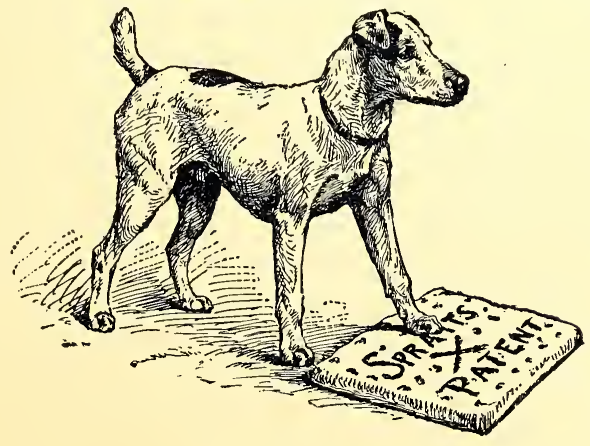

Ask

SPRATT'S Patent, Ltd. 245 E. 56th Street NEW YORK

to send you their free catalogue of dog and

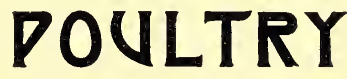

foods, etc., with hints on feeding, care, etc. 
plak 4.

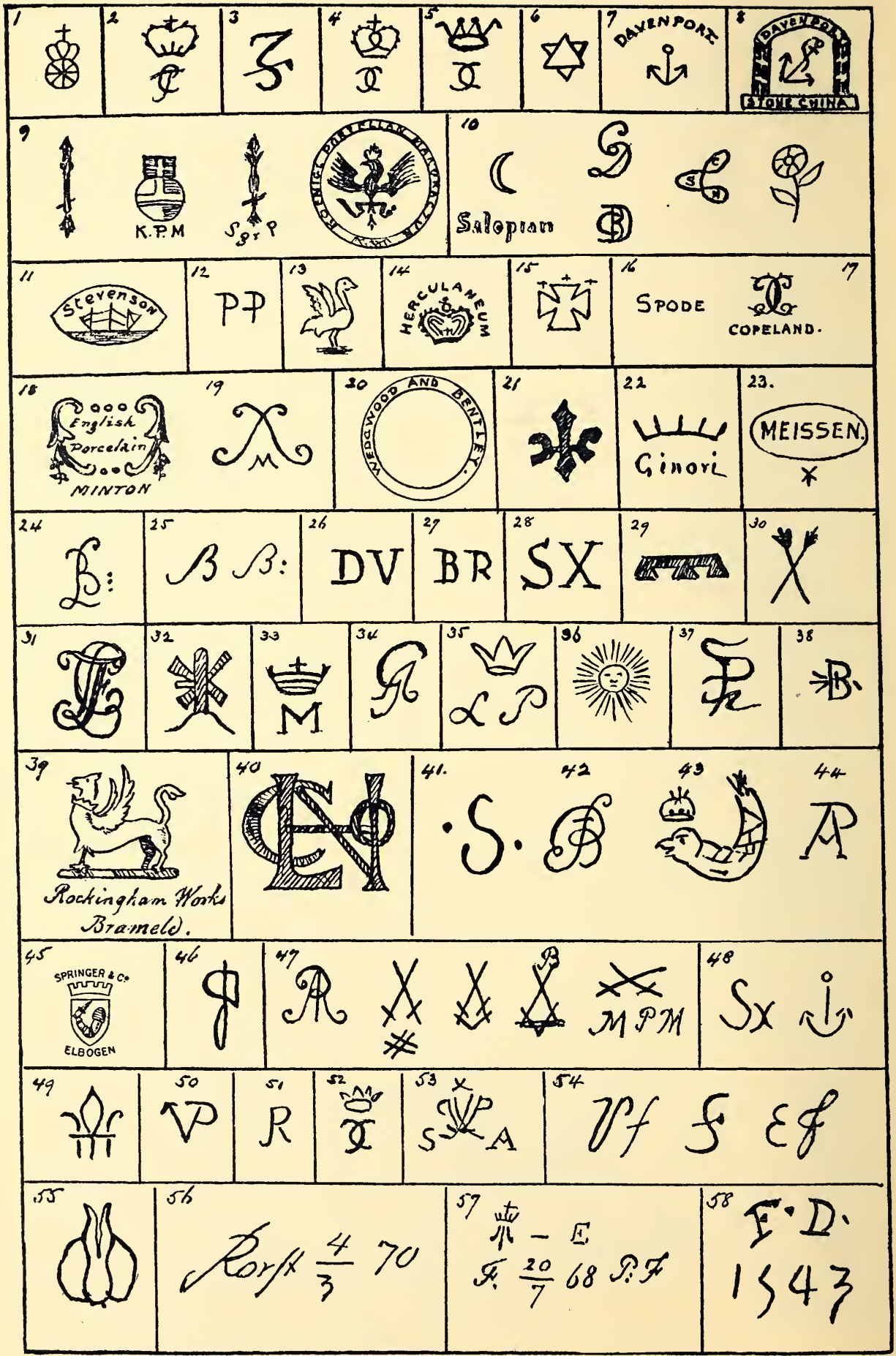




\title{
19OSCHERAK BROS.
}

47 MURRAY STREET

NEW YORK

Importers of ...

HIGH-GRADE BOHEMIAN, FRENCH

CRYSTAL AND DECORATED $*$

ฯ GI

"With whatever disdain the collector of Dresden and Sevres may now look down on the blue-printed crockeries of Clews and Wood and Ridgway, the day will come when Ceramic specimens of our first steamships, our first railways, the portraits of our distinguished statesmen, soldiers and sailors, the openings of our canals, the various events of our wars, will rank in historical collections with the vases of Greece. And whatever then be the estimate of the art they exemplify, men will say, "These show the tastes, these illustrate the bome life of the men and women who were the founders and rulers of the American Republic."-W. C. Prime.

\section{ENGLISH POTTERS}

\section{and American History}

$\mathrm{E}^{\mathrm{s}}$

ARLY in the present century both Staffordshire and Liverpool sent us vast quantities of printed earthenware with subjects relating to our heroes, our statesmen and our country. To describe these fully with historical, biographical or descriptive notes, carefully compiled from the most authentic sources, so that "English Potters and American History," may become the recognized text book on the subject, is the aim of the author.

Especial attention will be given to the Illustrations, and over one hundred subjects have already been selected, which will be produced of such a size as to render perfectly all details.

(

Collectors owning rare $s u b j e c t s$ are earnestly requested to ... place themselves in communication with me.

6
WILL BE READY IN TIME FOR THE HOLIDAYS

\section{W. P. JERVIS, 62 James Street NEWARK, N.J.}

\section{THE NEOSTYLE DUPLICATOR}

enables any boy to take 2,000 Copies from one originals

\author{
* WRITING OR TYPEWRITING $\nsim \propto$
}

NEOSTYLE CO., 96-102 Church Street, New York 

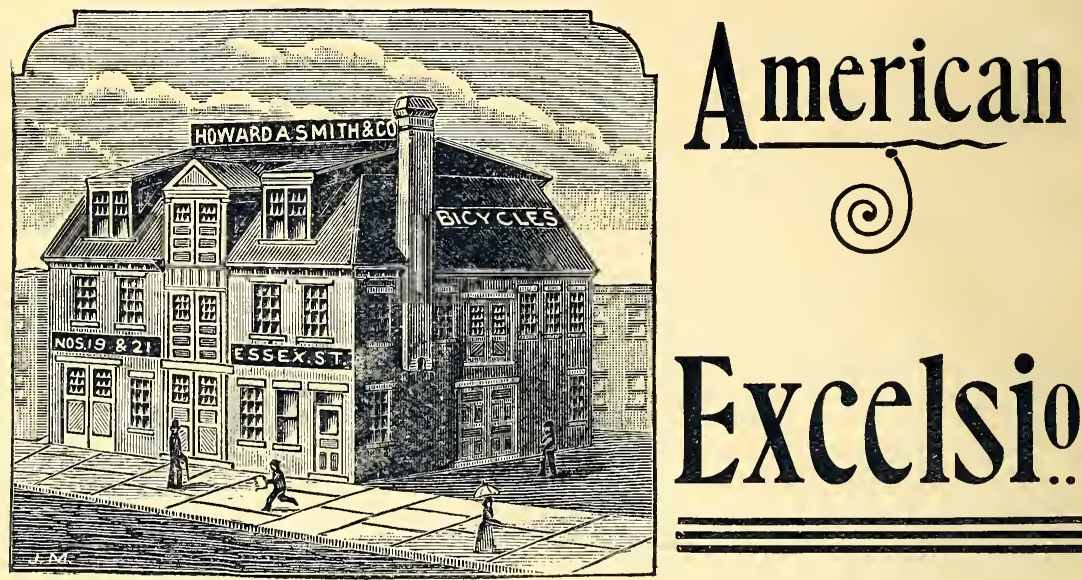

BUILT TO RIDE AND FULLY GUARANTEED

Complete Mechanical facilities, experienced 2. Workmen, and 15 YEARS in the Bicycle Business justifies us in asking you to look over the ...

\section{AMERICAN EXCELSIORS...}

(e)

Before you purchase a Bicycle call at our Factory ...

19 Essex Street

between James and Orange Sts.

NEWARK, N. J.

\section{HOWARD A. SMITH E CO.}


